\title{
9. MESOZOIC FORAMINIFERS AND DEEP-SEA BENTHIC ENVIRONMENTS FROM DEEP SEA DRILLING PROJECT SITES 415 AND 416, EASTERN NORTH ATLANTIC
}

\author{
William V. Sliter, ${ }^{1}$ U.S. Geological Survey, Menlo Park, California
}

\begin{abstract}
Mesozoic foraminifers recovered from DSDP Leg 50 Sites 415 and 416 in the Moroccan Basin of the eastern North Atlantic range in age from Late Jurassic to middle Cenomanian.

At Site 415 , sediments range in age from late Albian to middle Cenomanian, as inferred from 19 species of planktonic foraminifers and selected benthic foraminifers. Assemblages are dominated by hedbergellids, whereas rotaliporids are few, and ticinellids are absent. Deposition took place beneath the calcite-compensation depth in a quiet, abyssal environment, at water depths of 3000 to 4000 meters. This environment received a regular influx of shallow-water material that decreased with time and was finally replaced by hemipelagic sediments.

Foraminifer assemblages of Site 416 range in age from Late Jurassic (Tithonian-Kimmeridgian) to early Cenomanian. The assemblages consist of 172 species of benthic foraminifers and three species of the planktonic genus Hedbergella, represented by seven specimens. During the Neocomian, shallow-water material was emplaced into a quiet, lower bathyal to abyssal environment beneath the calcite-compensation depth, at water depths of 2000 meters or more. As a result of this high rate of sedimentation, 35 of the 53 Mesozoic cores are Valanginian. Before and after the Neocomian, the rate of sedimentation was lesser. Foraminifers representative of slope environments are found throughout the Upper Jurassic and Neocomian; they are strongly similar to shelf assemblages and comprise nodosariids and simple, agglutinated species.
\end{abstract}

\section{INTRODUCTION}

Mesozoic foraminifers were recovered from Sites 415 and 416, drilled during DSDP Leg 50 in the eastern North Atlantic off the coast of Morocco (Figure 1). Both sites are on the lower continental slope, within the Moroccan Basin; Site 415 is near Agadir Canyon, and Site 416 is near Site 370 of Leg 41 (Table 1). The Late Jurassic to middle Cretaceous foraminifer faunas provide valuable biostratigraphic information and permit environmental reconstructions in a deep-water environment, although the faunas are, in general, of low diversity and abundance and are poorly preserved. The faunas and lithologies at both sites indicate deposition in a deep-sea environment below the calcite-compensation depth (CCD) that characteristically received regular influxes of distal turbidites. Consequently, foraminifer recovery was sporadic, and specimens generally are sorted hydrodynamically to a range between 63 and 149 $\mu \mathrm{m}$. Because of differences in age and faunal content, foraminifers from Sites 415 and 416 are treated separately here. At Site 415 , planktonic foraminifers are

\footnotetext{
${ }^{1}$ Present address: U.S. Geological Survey, National Center, Reston, Virginia, 22092.
}

used for correlation, whereas at Site 416 the dominant benthic foraminifers form the basis for biostratigraphic interpretation.

The Mesozoic faunas allow close correlation with DSDP sites of earlier legs within the North Atlantic. Most notable among these are Sites 136 and 137 of Leg 14 , off northwest Africa; Sites 367, 368, 369, and 370 of Leg 41; and Sites 101 and 105 of Leg 11, from the BlakeBahama Abyssal Plain, in the northwestern Atlantic.

\section{SITE 415}

Site 415 was selected in an attempt to penetrate preLate Jurassic sediments close to a rifted continental margin; site selection was based on the results of Leg 41 (Site 370). Because drilling at Site 370 had reached a depth of 1,176 meters, Hole $415 \mathrm{~A}$, the principal hole of three drilled at Site 415, was discontinuously cored; cores were taken about every 70 meters to a sub-bottom depth of 1,079.5 meters. There were three successful reentries (Table 1). Unstable hole conditions forced the abandonment of the site. The penultimate core, $415 \mathrm{~A}-$ 14 , was highly fractured and calcite-veined mudstone that apparently was subject to continued and excessive caving. As a result, the foraminifer assemblages in the final two cores contain common down-hole contaminants. 


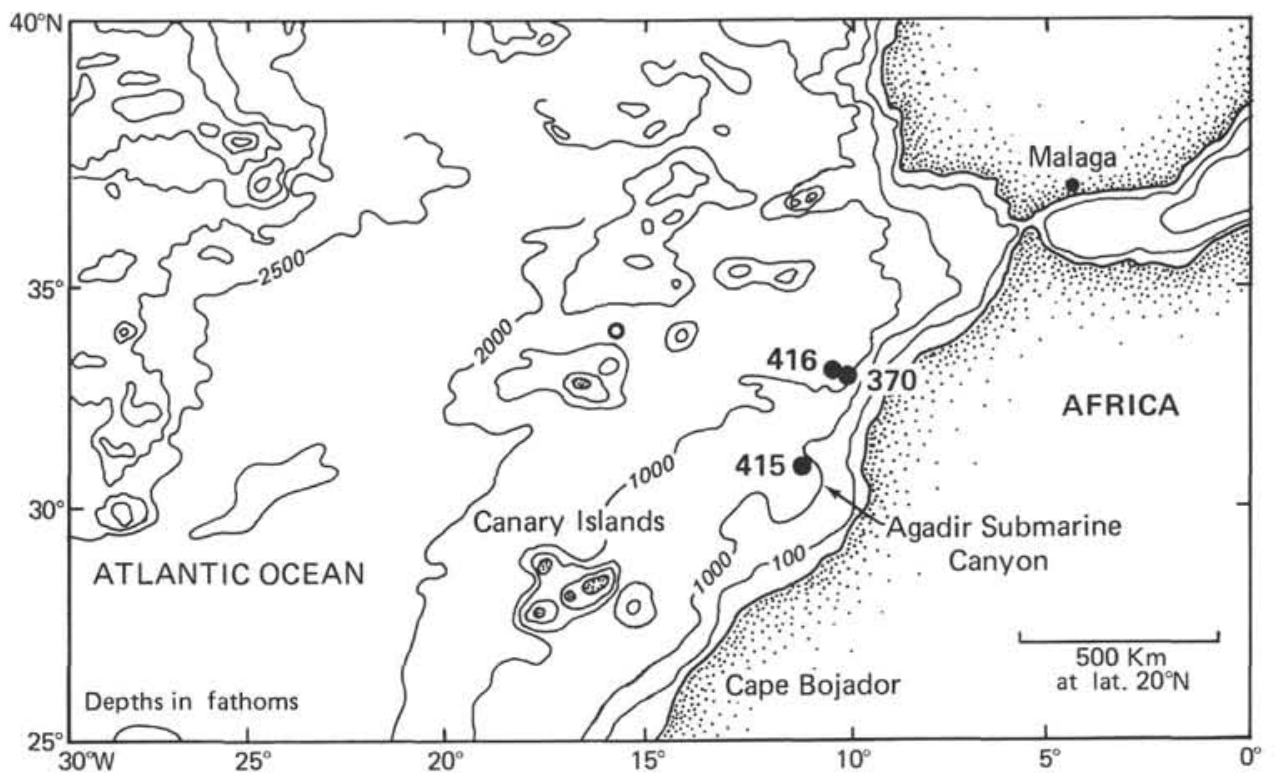

Figure 1. Location of Sites 415 and 416 of Leg 50 and Site 370 of Leg 41, off the northwest coast of Africa.

TABLE 1

General Data on Primary Holes of Leg 50

\begin{tabular}{lcccccc}
\hline Hole & Latitude & Longitude & $\begin{array}{c}\text { Water } \\
\text { Depth } \\
(\mathrm{m})\end{array}$ & $\begin{array}{c}\text { Penetration } \\
(\mathrm{m})\end{array}$ & $\begin{array}{l}\text { Recovery } \\
\text { Per Cent }\end{array}$ & $\begin{array}{c}\text { Number of } \\
\text { Cores in } \\
\text { Mesozoic }\end{array}$ \\
\hline $415 \mathrm{~A}$ & $31^{\circ} 01.72^{\prime} \mathrm{N}$ & $11^{\circ} 39.11^{\prime} \mathrm{W}$ & 2794 & 1079.5 & 20 & 8 \\
$416 \mathrm{~A}$ & $32^{\circ} 50.18^{\prime} \mathrm{N}$ & $10^{\circ} 48.06^{\prime} \mathrm{W}$ & 4191 & 1624 & 47.3 & 52 \\
\hline
\end{tabular}

Planktonic-species distributions form the primary basis for the following age determinations and correlations. The low-diversity fauna consists of nine genera and 19 species (Figure 2). Faunas are dominated by hedbergellids, numbers of specimens are low, and preservation is moderate to poor.

\section{Planktonic-Foraminifer Zonation}

The composite planktonic zonation used in this paper (Figure 3 ) is based on recent schemes by van Hinte (1976) and Premoli-Silva and Boersma (1977) for the South Atlantic and Sigal (in press) for the North Atlantic. The 19 species of Cretaceous planktonic foraminifers recognized from Site 415 represent four zones, from late Albian to middle Cenomanian. The reader is referred to the cited works for descriptions of the zones. The selected datum levels are based in part on Thierstein (1976) and Premoli-Silva and Boersma (1977).

\section{Biostratigraphy of Hole 415A}

\section{Albian}

Cores 415A-14 and 415A-15, greenish-black marlstone and olive-gray, calcareous claystone, are assigned to the upper-Albian Rotalipora appenninica-Planomalina buxtorfi Zone. The presence of Rotalipora appenninica, Praeglobotruncana delrioensis, Schackoina cenomana, S. multispinata, and Guembelitria cenomana and the absence of species of Ticinella are consistent with this assignment (Figures 2 and 3 ). Rare specimens of Rotalipora evoluta, Clavihedbergella simplex, and Rotalipora cushmani with this interval probably result from caving during drilling. The low-diversity benthic fauna (Appendix 1, faunal reference list; barren or nondiagnostic samples are listed in Appendix 2), with Textularia foeda, Spiroplectinata complanata, Lenticulina gaultina, Vaginulina debilis, $V$. gaultina, Lingulina lamellata, and Gavelinella intermedia, is compatible with an Albian assignment. Foraminifer abundance is low in this interval, preservation moderate to poor, and the effects of dissolution moderate.

\section{Cenomanian}

Core 415A-13, dark-greenish-gray mudstone to shale, is assigned to the early Cenomanian. The faunal assemblage is similar to that of the underlying cores, with the addition of Rotalipora evoluta, believed to be in place. Species of Hedbergella and Globigerinelloides are more abundant; preservation and dissolution effects remain about the same.

From Core 415A-12 through Sample 415A-8-2, 105-107 cm, the sediments belong to the early- to middle-Cenomanian Rotalipora cushmani Zone. Species that occur within this interval include Rotalipora cushmani, R. evoluta, $R$. appenninica, Clavihedbergella simplex, Gubkinella graysonensis, Praeglobotruncana delrioensis, and $P$. stephani. The section can be divided into three intervals based on the planktonic fauna.

Cores $415 \mathrm{~A}-12$ and $415 \mathrm{~A}-11$ and Sample $415 \mathrm{~A}-$ 10-CC, predominantly olive-gray, calcareous shale, contain the greatest abundance of Rotalipora cushmani, as well as common representatives of species of Hedbergella and Globigerinelloides. Hedbergella sp. cf. H. delrioensis makes its final appearance within this interval, 


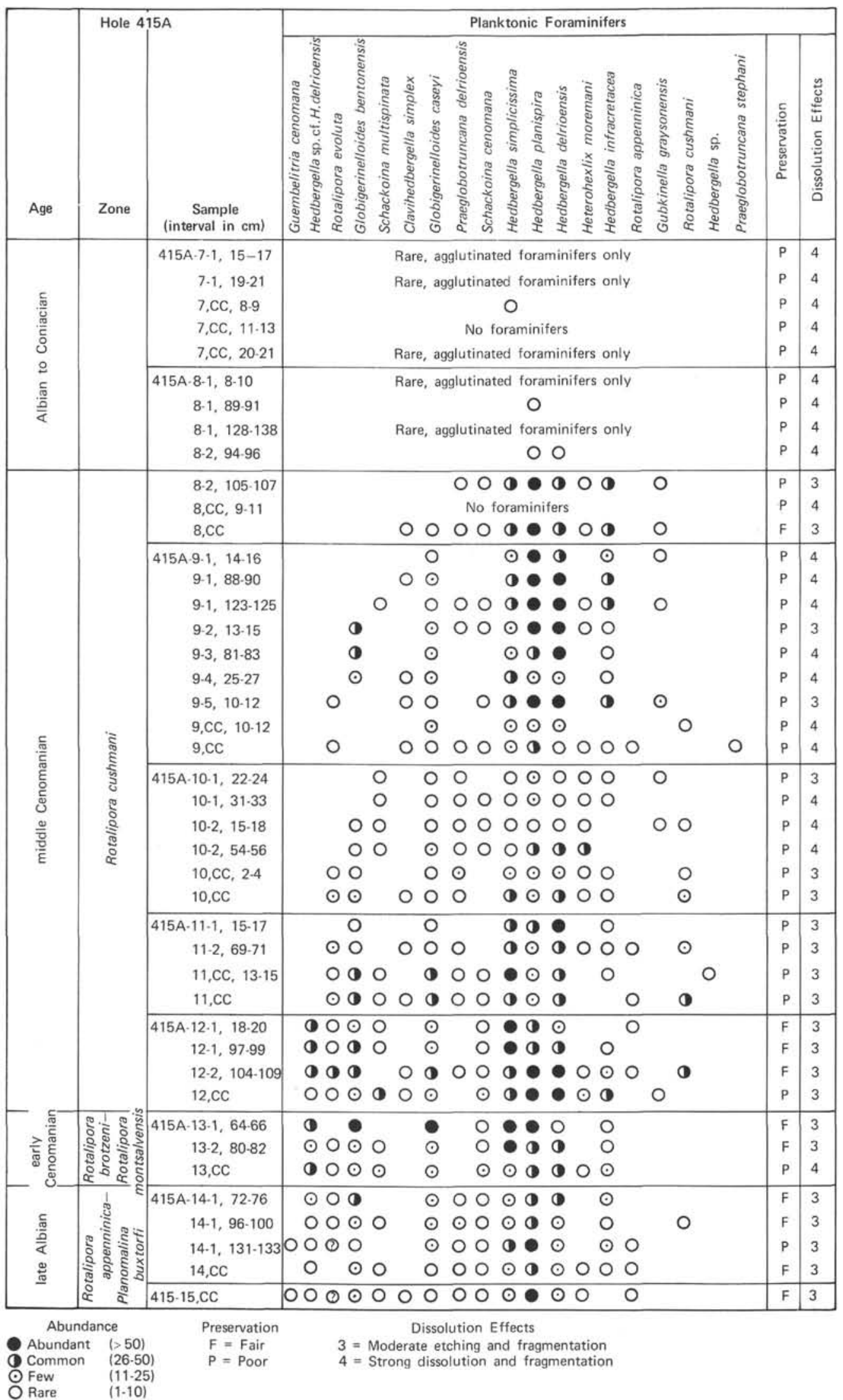

Figure 2. Distribution of Cretaceous planktonic foraminifers and foraminifer preservation at Site 415. Abundance (numbers of specimens) based on assemblage larger than $105 \mu \mathrm{m}$. 
Planktonic-Foraminifer Zones

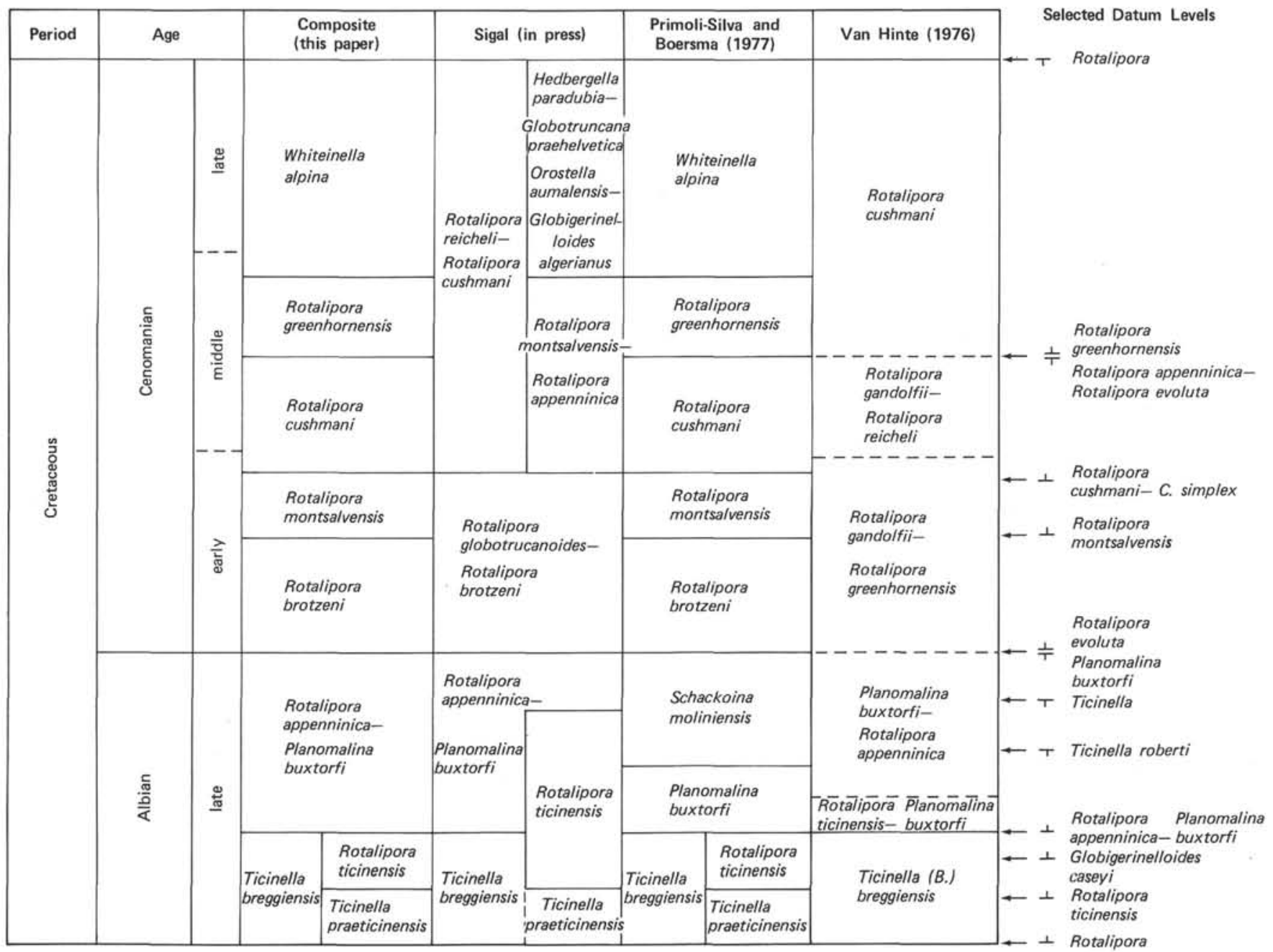

Figure 3. Planktonic-foraminifer zones and selected datum levels. Datum levels in part after Moullade (1973), Porthault (1974), Thierstein (1976), and Premoli-Silva and Boersma (1977).

which also includes the stratigraphically restricted specimens of Hedbergella sp. Preservation is poor to moderate, and the effects of dissolution are moderate.

The second interval (Core 10) contains a much reduced, poorly preserved fauna. The sediments are olivegray, pyrite-bearing marlstone, with intervals of contorted stratification. Smaller specimens are relatively abundant, and there is a noticeable reduction in rotaliporids.

The third interval (Core 9) shows a renewed abundance of Hedbergella and Globigerinelloides, with rare specimens of Rotalipora. Sediments are dark-greenishgray marlstone, and there is considerable evidence of disturbed bedding. The sporadic and repetitious nature of the fauna within these three intervals and the preservation patterns and presence of disturbed sediments suggest the effects of gravitational sliding and consequent increased dissolution in the more exposed or fractured intervals. Alternatively, changes in the corrosiveness of the bottom waters, fracturing of the strata associated with adjacent up-slope salt-dome emplacement, or vertical fluctuations of the CCD could produce similar results. On the basis of the faunal and lithologic patterns, the hypothesis of dissolution as a consequence of gravitational sliding is believed to be the most plausible.

\section{Albian-Coniacian}

The interval of Sample 415A-8-2, 94-96 cm through Core 415A-7 contains very few planktonic species and is characterized by strong carbonate dissolution and only rare, deep-water, agglutinated foraminifers. The rare specimens of Hedbergella indicate an age no younger than Coniacian. Sediments in Core $415 \mathrm{~A}-7$ consist of homogeneous olive-gray mudstone; Core $415 \mathrm{~A}-8$ is blue-green, calcareous mudstone to shale. Radiolarians within this interval show zeolitic alteration. The combination of strong carbonate dissolution, lowered sedimentation rates, and development of zeolites correlates these sediments with the dissolution facies or barren in- 
terval that characteristically extends from the upper Cenomanian to the middle Santonian in oceanic sediments (Sliter, 1976, 1977).

\section{Paleoecology}

\section{Depositional Environment}

Deposition of the Cretaceous sediments at Site 415 took place in a quiet, abyssal environment, at water depths of 3000 to 4000 meters, beneath the CCD. There was a regular influx of fine-grained, terrigenous sediment. Terrigenous sediments decrease upward to Cores $415 \mathrm{~A}-7$ and $415 \mathrm{~A}-8$, where they are replaced largely by hemipelagic sediments. Deposition of the terrigenous silts and clays took place by very distal resedimentation processes generated by traction flows or turbidity currents. These processes mixed biogenic material from shallow and intermediate water depths with resuspended autochthonous material. As a result, the recovery and preservation of the foraminifer assemblages at Site 415 , and indeed of all the calcareous material, is strongly affected by the mode of sedimentation and the sediment type. The dominant lithology at Site 415 is calcareous or dolomitic shale or mudstone. Foraminifers and calcareous nannofossils contribute less than five per cent of the carbonate, the rest apparently being diagenetic carbonate. Bioturbation consists primarily in horizontal or nearly horizontal Chrondites burrows adjacent to the fine-grained sandstone or siltstone beds.

The foraminifer assemblages and biogenic components plotted in Figure 4 illustrate these changes. A deep-sea foraminifer assemblage is found throughout the sediments of Hole $415 \mathrm{~A}$; however, it is strongly diluted in Cores $415 \mathrm{~A}-11$ through $415 \mathrm{~A}-15$ by redeposited bathyal and neritic faunas. The autochthonous assemblage includes species of Bathysiphon, Hyperammina, Hippocrepina, Lituotuba, Saccammina, Glomospira, Glomospirella, Ammodiscus, Recurvoides, Reophax, Ammobaculites, Gaudryina, and Trochammina. These foraminifers are indicative of Cretaceous abyssal water depths of 3000 to 4000 meters (Sliter and Baker, 1972; Sliter, 1976, 1977).

The dominant neritic assemblage of Cores 415A-11 to $415 \mathrm{~A}-15$ is characterized by nodosariids, such as species of Astacolus, Dentalina, Frondicularia, Lagena, Lenticulina, Nodosaria, Saracenaria, Vaginulina; fistulose polymorphinids; large agglutinated species of Dorothia, Tritaxia, Textularia, and Chofatella; and miliolids that include species of Quinqueloculina, Spiroloculina, and Nodobacularia. This assemblage is indicative of water depths no greater than 400 to 500 meters. Also present in these cores are carbonaceous material, Inoceramus prisms, holothurian plates, echinoid spines, ostracodes, and rare calcisphaerulids, among other components. The calcareous material is better preserved, probably because of the buffering action of the greater carbonate content and the protection from corrosive bottom waters by rapid accumulation. Rare well-cemented calcarenite with shallow-water carbonate detritus is confined to this interval.
Cores 9 and 10 contain a dominant bathyal foraminifer component, as evidenced by species of Praebulimina, Neobulimina, Stilostomella, Bolivina, Pleurostomella, Ellipsoidella, Allomorphina, Gavelinella, Gyroidinoides, and Osangularia, among others. Both middle-bathyal (500-1500 m) and lower-bathyal (1500-2500 $\mathrm{m})$ elements are present in the mixed assemblages; however, the assemblages are hydrodynamically sorted, and size distributions are skewed in favor of the smaller, lower-bathyal species. Neritic species make their final common appearance in Section 415A-9, CC. Fish debris, radiolarians, and diatoms increase and are accompanied by echinoid spines, ostracodes, and thinshelled-bivalve fragments. Inoceramus prisms and miliolids become rare or disappear within this interval.

The abyssal assemblage becomes dominant in Cores 415A-7 and 415A-8, where it is accompanied by abundant fish debris and radiolarians. Radiolarians from Sample 415A-8-1, 8-10 cm to the top of Core 415A-7 are replaced by zeolites in this dissolution facies associated with the mid-Cretaceous hiatus.

The upward decrease in the terrigenous component is documented by the ratio of planktonic to benthic foraminifers and by the abundance of fragmented planktonic specimens (Figure 4). Planktonic species become relatively more abundant upward as the dilution by allochthonous benthic foraminifer lessens. Likewise, fragmentation of planktonic foraminifers increases upward as the protection offered by the terrigenous sediments lessens and the foraminifers are exposed to bottom waters for longer periods between flows.

Sample 415A-9, CC and samples from Core 415A-10 differ somewhat from adjacent samples in their foraminifer assemblage, biogenic content, and fossil preservation. These differences again may attest to gravity sliding within this interval.

\section{Effect of Sedimentation}

The effects of resedimentation and vertical sorting in the very distal turbidites of Site 415 are illustrated in Figure 5. Three examples are shown, two illustrating differences within turbidite cycles and one differences between marlstones differentiated by color within the upper unit of a turbidite cycle.

Samples $415 \mathrm{~A}-10-2,12-13 \mathrm{~cm}, 15-17 \mathrm{~cm}$, and 17-18 $\mathrm{cm}$ record a single cycle, from a basal fine-grained sandstone to a greenish marlstone. Planktonic foraminifers are rare in the sandstone and overlying grayish-olive marlstone. Still, some evidence of sorting is seen in the restriction of the larger rotaliporids to the basal sandstone and the smaller species of Schackoina to the overlying grayish-olive marlstone. The mixed benthic assemblage in the sandstone consists of bathyal and neritic species that are found with abundant small, smooth and ornamented ostracodes (many with blackened carapaces), common echinoid spines, and rare miliolids, holothurian plates, and thin bivalve fragments. Pyrite is present as chamber fillings in planktonic foraminifers and as sporadic framboids. 


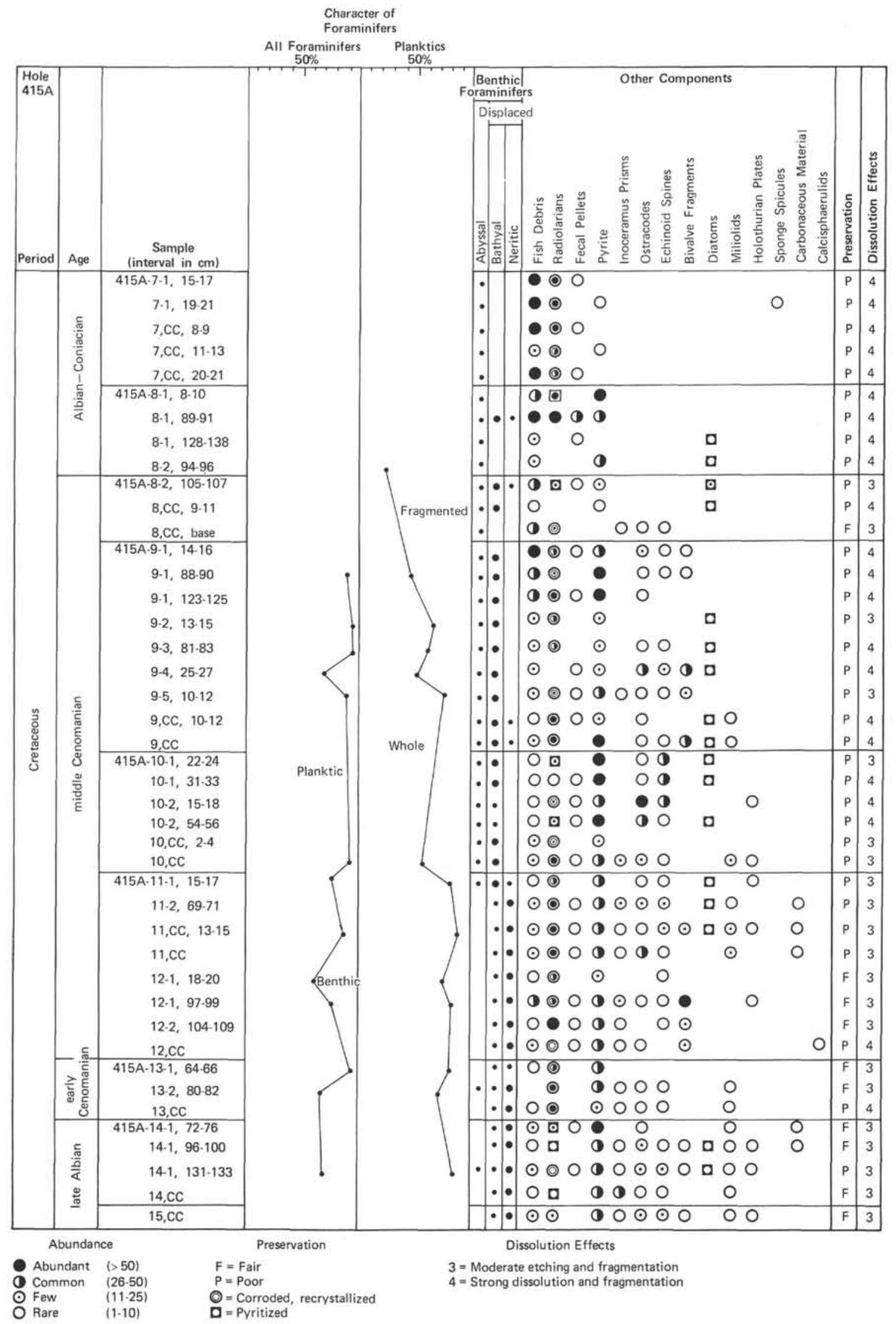

Figure 4. Distribution and character of selected biogenic and lithologic components at Site 415. Relative abundance among benthic foraminifers of various depth zones shown by size of symbol. Relative abundance of benthic and planktonic foraminifers based on 300-specimen counts of fraction greater than $105 \mu \mathrm{m}$. 


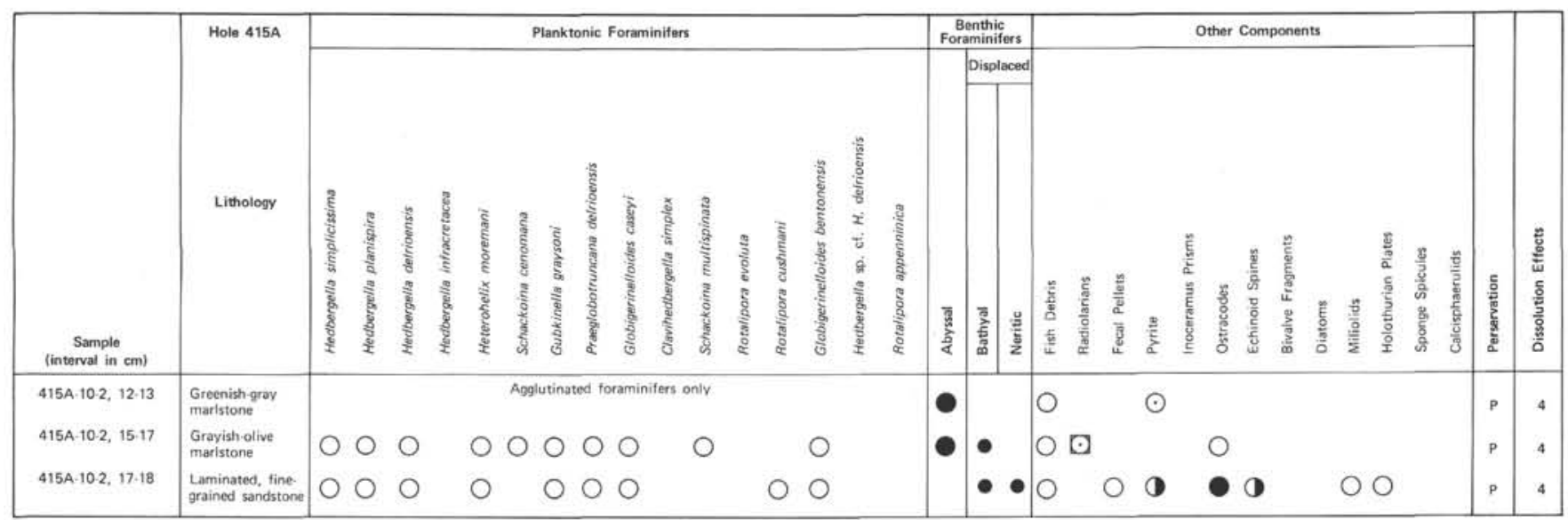

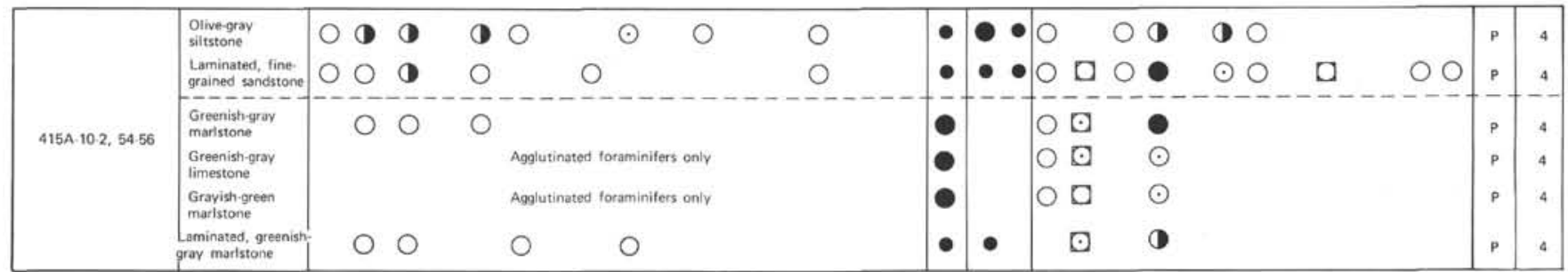

\begin{tabular}{|c|c|c|c|c|c|}
\hline $415 A \cdot 12 \cdot 2,1$ & 04.105 & $\begin{array}{l}\text { light-olive green } \\
\text { marlstone }\end{array}$ & 10 & $\odot \odot \bigcirc 0$ & $0 \odot 0$ \\
\hline 415A-12-2. & 07.109 & $\begin{array}{l}\text { Homogoneous, } \\
\text { dark-greenish- } \\
\text {-oray maristone }\end{array}$ & $\odot$ & 1000 & $\bigcirc \odot 0$ \\
\hline At & & \multicolumn{2}{|c|}{ Preservation } & \multicolumn{2}{|r|}{ Effects } \\
\hline $\begin{array}{l}\text { Abundant } \\
\text { Common } \\
\text { Few } \\
\text { Rare }\end{array}$ & $\begin{array}{l}(>50) \\
(26-50) \\
(11.25) \\
(1-10)\end{array}$ & \multicolumn{2}{|c|}{$\begin{array}{l}F=\text { Fair } \\
p=\text { Poor } \\
\text { D - Pyritized }\end{array}$} & \multicolumn{2}{|c|}{$\begin{array}{l}2 \text { - Slight etching and framentation } \\
3 \text { = Moderate etching and frapmentation } \\
4=\text { Strong dissolution and tragmentation }\end{array}$} \\
\hline
\end{tabular}

Figure 5. Distribution of planktonic foraminifers and selected biogenic and lithologic components in separate units of turbidite cycles at Site 415. Planktonic-foraminifer abundance from assemblage greater than $105 \mu \mathrm{m}$; biogeniccomponent abundance from assemblage greater than $63 \mu \mathrm{m}$. Relative abundance of abyssal, bathyal, and neritic foraminifers shown by size of symbols. Dashed line represents boundary between turbidite cycles.

An autochthonous, abyssal assemblage appears in the grayish-olive marlstone, together with bathyal species, pyritized radiolarians, fish debris, and rare ostracodes. The abyssal assemblage continues to the dissolution facies of the upper greenish-gray marlstone, where the planktonic foraminifers and other calcareous biogenic materials have been removed. Pyrite is present as framboids and sporadic fillings of agglutinated foraminifers.

Sample 415A-10-2, 54-56 cm contains the boundary (dashed in Figure 6) between two cycles. In the upper cycle, smaller species of Hedbergella and Schackoina are again more abundant in an olive-gray siltstone that overlies a laminated, fine-grained basal sandstone. The sandstone contains abyssal benthic foraminifers with bathyal and neritic species of moderately large size, together with pyritized radiolarians and diatoms, calcisphaerulids and sponge spicules. Pyrite is most abundant in foraminifers $(89 \%)$; lesser amounts are present as framboids $(10 \%)$ and pyritized radiolarians $(1 \%)$. The overlying siltstone shows an increase in bathyal species and smooth ostracodes. Pyrite is distributed between foraminifers $(70 \%)$ and framboids.

A laminated, greenish-gray marlstone at the base of the underlying cycle is nearly equivalent to the olive- gray siltstone of the upper cycle. A small, allochthonous, bathyal fauna is mixed with an abyssal foraminifer assemblage. Pyrite is found mostly as framboids $(70 \%)$; the rest is distributed among pyritized radiolarians $(20 \%)$, burrow fillings $(7 \%)$, and foraminifers $(3 \%)$. Overlying this is a grayish-green marlstone. Higher in the cycle, is a greenish-gray limestone, which presumably resulted from dissolution of pelagic carbonate from the underlying marlstones. In the limestone and immediately subjacent marlstone, pyrite is nearly evenly distributed between framboids and burrow fillings. The final unit, a greenish-gray marlstone, represents perennial sediment; it contains a meager planktonic fauna, abyssal benthic species, and fish debris. Pyrite is present as framboids (89\%) and as fillings in agglutinated $(10 \%)$ and planktonic $(1 \%)$ foraminifers.

The third example, Samples 415A-12-2, 104-105 cm and 107-109 $\mathrm{cm}$, shows faunal differences between a homogeneous, dark-greenish-gray marlstone and an overlying laminated, light-olive-green marlstone. Both units contain a moderately diverse planktonic fauna; however, the larger rotaliporids are more common in the laminated marlstone. The laminated marlstone also contains more and better-preserved neritic benthic fora- 


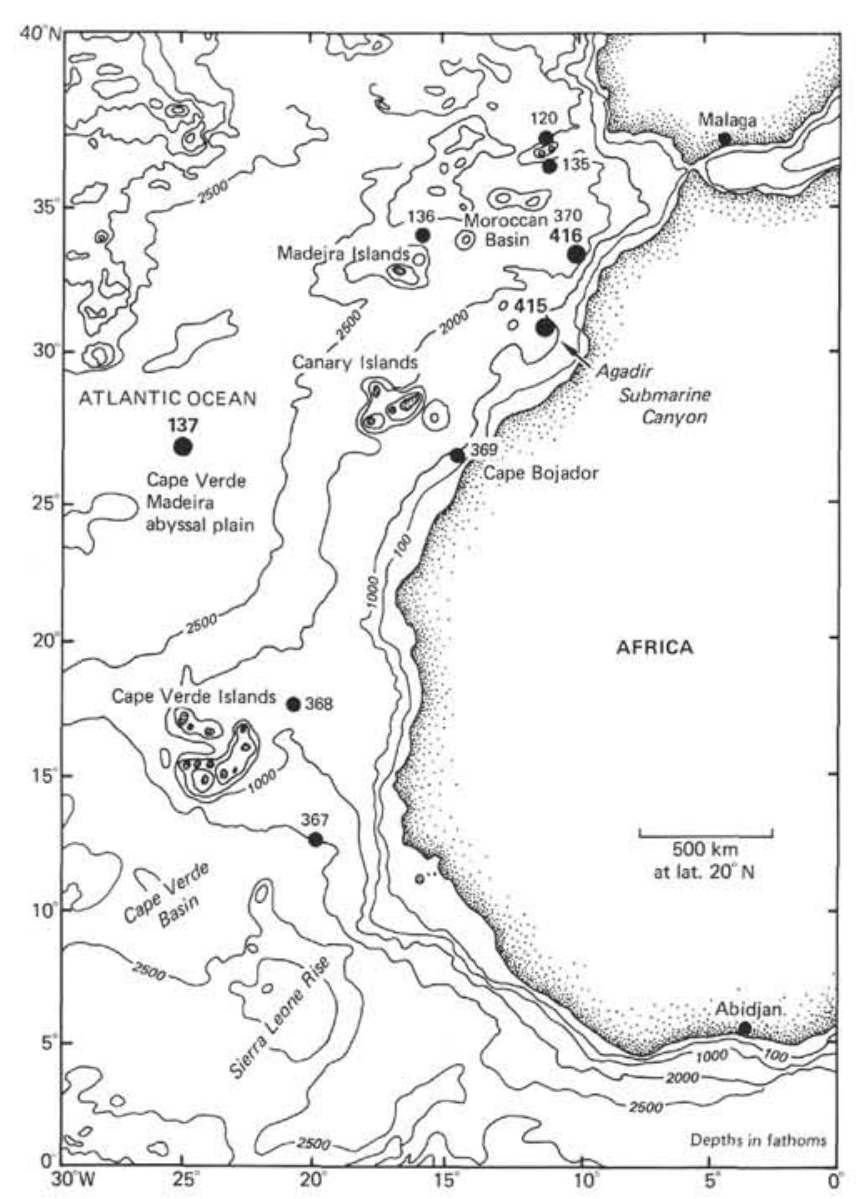

Figure 6. Location of previous DSDP sites (Legs 13, 14, 41) off northwest Africa that contain middle-Cretaceous foraminifers.

minifers. Pyrite is similarly distributed in both units; it is found as fillings in foraminifers $(60 \%)$, radiolarians $(20 \%)$, and burrows $(1 \%)$, and as framboids $(19 \%)$.

In all three examples, the primary inprint of downslope bottom flows can be seen in the mixed assemblages of the sands and laminated siltstones and in the concentration of larger-sized and heavier biogenic debris in the basal units.

\section{Faunal Comparisons}

Foraminifers from Site 415 are comparable to those from Sites 136 and 137 of Leg 14 and Sites 367, 368, 369 , and 370 of Leg 41, off northwest Africa (Figure 6). Of these assemblages, those from Site 370 reported by Pflaumann and Krasheninnikov (1978) are very similar; Site 370 is about $350 \mathrm{~km}$ northeast of Site 415 , at a water depth of 4,216 meters. Cores 370-20 through 370-24 contain a late-Albian to early-Cenomanian fauna with Rotalipora appenninica, Praeglobotruncana delrioensis, Hedbergella delrioensis, $H$. planispira, $H$. infracretacea, $H$. simplicissima, and $H$. simplex, among other species. Cores $370-25$ to $370-26$ have a similar fauna, but lack species of Rotalipora and Ticinella. Pflaumann and Krasheninnikov attribute these cores to the upperAlbian Rotalipora ticinensis Zone. Cores 370-20 through
370-26 thereby correlate closely with Cores $415 \mathrm{~A}-13$ to 415A-15. In contrast, Albian sediments of Site 369, at a water depth of 1,760 meters, off Spanish Sahara, are older than those of Site 415 , as indicated by such species as Ticinella roberti, $T$. primula, and $T$. raynaudi, together with Rotalipora subticinensis.

The poorly preserved, sporadic, planktonic fauna from Site 368, at a water depth of 3,367 meters, on the Cape Verde Rise, includes Hedbergella delrioensis, $H$. planispira, H. simplicissima, Heterohelix sp., and Guembelitria sp. and is assigned an Albian to Turonian age by Pflaumann and Krasheninnikov. Site 367, at a water depth of 4,748 meters, in the Cape Verde Basin, again contains faunas that span the Albian-Cenomanian boundary. Core 367-19 through Section 367-21-6 are Cenomanian, on the basis of Hedbergella brittonensis, Heterohelix moremani, and Guembelitria harrisi. This assemblage is followed in Cores 367-21 and 367-22 by an Albian assemblage that contains Ticinella primula and $T$. raynaudi and is therefore older than the basal sediments of Site 415.

There are strong similarities with faunas from Site 137 of Leg 14, described by Beckmann (1972). This site is at a water depth of 5,361 meters, in the Cape Verde-Madeira Abyssal Plain. The interval of Cores 137-8 through Section 137-12-1 contains a middle-Cenomanian fauna typified by Rotalipora appenninica, $R$. brotzeni, $R$. cushmani, $R$. evoluta, $R$. greenhornensis, $R$. balernaensis, and $R$. reicheli. Sections 137-12-1 through 137-15, CC include Rotalipora evoluta, $K$. balernaensis, and other species that indicate an earlyCenomanian age. Following an interval from Sections 137-16-1 through 137-16-3 which contains questionable Rotalipora evoluta and Praeglobotruncana delrioensis, the late Albian is recognized in the interval of Section 137-16-3 through sidewall core 137-1, on the basis of Ticinella raynaudi digitalis, Rotalipora ticinensis, Planomalina buxtorfi, Hedbergella trocoidea, Globigerinelloides breggiensis, and other species. This sequence, Cores 137-8 through 137-16-3, closely correlates with Cores 415A-8 through 415A-15.

Site 136 of Leg 14 lies north of Madeira in an area of abyssal hills, at a water depth of 4169 meters. A meager and questionable Albian fauna of Hedbergella amabilis $(=H$. simplicissima $), H$. planispira, and Globigerinelloides tururensis may be comparable to the fauna of the lower cores of Hole 415A.

Finally, Site 120 of Leg 13, at a water depth of 1711 meters, on Gorringe Bank, west of Portugal, contains an Albian fauna (Maync, 1973). The planktonic fauna is limited to a single specimen of Hedbergella cf. H. infracretacea; the varied benthic assemblage, however, indicates an age somewhat older than that of the basal sediments of Site 415 .

\section{SITE 416}

Site 416 is in the Moroccan Basin about $2 \mathrm{~km}$ west of Site 370 . This site was chosen primarily because it was known, after the earlier drilling on Leg 41, that pre-Late Jurassic rocks were within reach. Because Hole 370 had 
reached a depth of 1176 meters, there was no need at Site 416 for continuous coring above that level. The exact positions of Cores $416 \mathrm{~A}-5$ to $416 \mathrm{~A}-9$, taken in this discontinuously cored interval, are difficult to determine. This is especially true for Cores $416 \mathrm{~A}-7$ and $416 \mathrm{~A}-8$, where drilling proceeded with the core barrel in place until the barrel filled or became plugged. As a consequence, the material contained in these cores is a mixture of the sediments within the extended cored interval and cavings from stratigraphically higher units. Coring was continuous from Core 416A-9 to Core 416A-57, shortly after which bottom hole conditions deteriorated and drilling was terminated.

Benthic-species distributions form the basis for the following biostratigraphic determinations and correlations. The identified fauna consists in 54 genera and 172 species (Appendix 3). Of these species, only three of the planktonic genus Hedbergella were recovered, seven specimens in all. The remaining 171 species of benthic foraminifers are divided into 122 forms with calcareous tests, 44 agglutinated species, and 5 miliolids. Foraminifer distributions from 141 samples are shown in Table 2. An additional 86 samples examined that were either barren or contained only rare nondiagnostic specimens are listed in Appendix 2.

\section{Biostratigraphy of Hole 416A}

\section{Tithonian-Kimmeridgian}

Core 416A-51 through Section 416A-57-1 are reddish-brown mudstone with layers of greenish-gray, micritic limestone; these rocks are assigned a Kimmeridgian and Tithonian age. Of particular interest are the occurrences of Bigenerina jurassica, Reophax helveticus, Epistomina uhligi, Textularia cordiformis, Trocholina conica, and Haplophragmoides haeusleri (Figure 7, Appendix). Specimen preservation in this interval is poor, as it is for most of the samples from Hole 416A; hence, the possibility of reworking cannot be disregarded. Nevertheless, in view of the continuity of faunal distributions and the sporadic influx of the associated shallow-water biogenic material, the writer believes that Hole 416A penetrated Jurassic sediments within this interval. The foraminifers do not indicate the presence of sediments older than Late Jurassic, although the prominent "Blue" reflector, believed to be of Kimmeridgian-Oxfordian age, might lie close beneath the bottom core. The Jurassic-Cretaceous boundary is therefore drawn at the faunal break between Cores 416A-50 and $416 \mathrm{~A}-51$, in the knowledge that this placement may be too high by several cores.

\section{Berriasian(?)}

A narrow interval of reddish-brown mudstone and greenish-gray, micritic limestone represented by Cores $416 \mathrm{~A}-49$ and $416 \mathrm{~A}-50$ contains an overlap of species whose ranges include the Upper Jurassic and Lower Cretaceous and species whose ranges begin in the Lower Cretaceous. This assemblage includes Haplophragmoides concavus, Dentalina communis, Vaginulinopsis matu- tina, Lagena oxystoma, and Pyrulina cylindroides. A questionable Berriasian age is assigned to this mixed-assemblage interval.

\section{Valanginian}

The Valanginian assemblage begins with Core 416A48 and extends upward through Core 416A-14. Sediments are predominantly terrigenous sandstone, siltstone, and mudstone, with some redeposited calcareous bioclastic material. Cycles of brownish terrigenous beds alternate with greenish-gray, carbonate-rich beds throughout this interval. However, greenish-gray micritic limestones are not found above Core 416A-36. Among the rocks penetrated in Hole 416A, this sequence of rapidly deposited sediments contains the greatest diversity of foraminifers; however, the numbers of specimens remain low, and preservation generally is poor. Of particular interest are the confinement to this interval of Lenticulina busnardoi and Trocholina valdensis and the first appearance here of species such as Epistomina anterior, Saracenaria frankei, S. saxonica, Lenticulina ouachensis ouachensis, L. nodosa, Dorothia kummi, D. praehauteriviana, Vaginulina recta, Trocholina infragranulata, and Epistomina caracolla (Figure 7).

\section{Hauterivian}

The Valanginian-Hauterivian boundary is placed between Cores 416A-13 and 416A-14, on the basis of the last appearance of Lenticulina busnardoi, the limited higher range of Lagena hauteriviana hauteriviana, and the first appearance of Dorothia hauteriviana, Lenticulina ouachensis multicella, and Lagena hauteriviana cylindracea. The Hauterivian assemblage extends from Cores 416A-9 through 416A-13. Sediments consist of cycles of greenish and brownish marlstone, with layers of grayish, fine-grained sandstone that become more common upward to Core 416A-9. Down-hole contamination is believed to be responsible for the presence of three poorly preserved specimens of the Barremian species Gavelinella barremiana in Core 12-3 (Figure 7, Appendix 3).

\section{Hauterivian-Barremian(?)}

Cores $416 \mathrm{~A}-7$ and $416 \mathrm{~A}-8$ are difficult to date, owing to problems of down-hole caving and limited core recovery. A Hauterivian to Barremian assemblage, with associated long-ranging species, characterizes this interval. Such species as Marginulinopsis collignoni, Dorothia hauteriviana, Lenticulina eichenbergi, L. ouachensis multicella, and Vaginulinopsis reticulosa indicate an age no younger than Barremian. Faunas remain sporadic and are characterized by rare, poorly preserved specimens. Sediments, too, resemble those of the underlying cores: cycles of greenish and brownish mudstone and some beds of fine sandstone and siltstone. Because of these similarities and the rare presence of such Barremian species as Gavelinella barremiana in Core 416A-8 and Frondicularia didyma in Core 416A-7, a questionable Hauterivian-Barremian age is assigned to these cores. However, the composition of the assemblage in- 


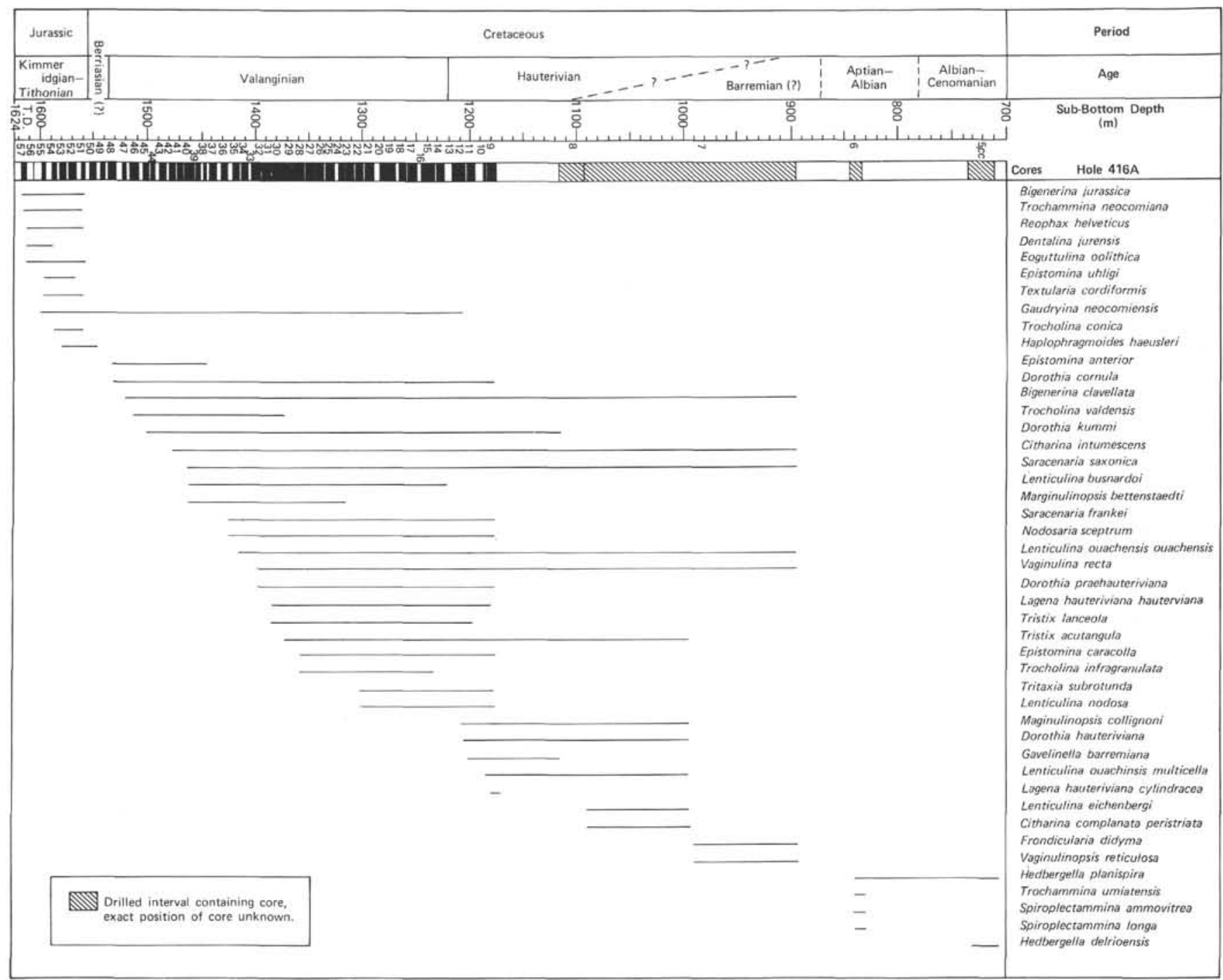

Figure 7. Stratigraphic distribution of selected benthic species at Site 416.

dicates that sediments of Barremian age are present within or just above the interval of Core 416A-7.

\section{Aptian-Cenomanian}

Core 416A-6 is assigned an Aptian-Albian age on the basis of the confinement to this interval of such species as Trochammina umiatensis, Spiroplectammina ammovitrea, and $S$. longa. Rare specimens of the planktonic species Hedbergella planispira signify an age no older than early Aptian. Sediments in Core 416A-6 are distinct from those below and consist predominantly of blue-green to olive-black, quartzose mudstone.

Foraminifers in Section 416A-5, CC are limited to six specimens of the planktonic species Hedbergella delrioensis, $H$. planispira, and $H$. infracretacea; these species indicate an Albian-Cenomanian age for this interval. Sediment in the core catcher consists of greenish-black to olive-black mudstone which contains deep-sea benthic foraminifers, fish debris, pyrite, and carbonaceous material. The biotic and lithologic association suggests a correlation of this interval with sediments at Site 415 which contain a similar association (Core 451A-7 and part of Core 415A-8). The correlation implies that Section 416A-5, CC falls within the mid-Cretaceous dissolution facies or barren interval that typically begins in the upper Cenomanian (Sliter, 1976, 1977).

\section{Paleoecology}

\section{Depositional Environment}

Mesozoic sediments at Site 416 were deposited in a quiet, abyssal environment beneath the $\mathrm{CCD}$, analogous to that for Cretaceous sediments at Site 415. The influx of terrigenous and redeposited shallow-water material into this environment reached a maximum during the late Valanginian, then was reduced greatly during the Aptian-Cenomanian (Figure 8). Deposition of lithologic Unit VII (see site report, this volume) was controlled primarily by distal turbidites, whereas the rapid deposition of Unit VI, though distal, probably took place on the outer edge of a prograding deep-sea fan system. The terrigenous sediments wane in Unit VI 
and are replaced by hemipelagic sediments and extremely distal turbidites in Unit $\mathrm{V}$ that were deposited on an abyssal plain. A deep-sea association of abyssal foraminifers and fish debris continues throughout the Mesozoic; however, it is often diluted and mixed with redeposited material and is hydrodynamically sorted. No radiolarians, diatoms, or holothurian plates were found in the Mesozoic sediments of Hole 416A. Pyrite in Figure 8 indicates pyritized foraminifers, framboids, or rare crystals.

Jurassic sediments (Cores 416A-51 through 416A-57) are dominated by deep-sea foraminifers, with the continued presence of displaced species, fish debris, and carbonaceous material. Inoceramus prisms, echinoid fragments, bivalve fragments, calcisphaerulids, and calpionellids are rare, attesting to the distal nature of the turbidite sedimentation.

The Valanginian to Berriasian(?) part of Unit VII (Cores 416A-37 through 416A-50) is characterized by an alternation in the dominance of deep-sea and displaced foraminifers. Fish debris is present in nearly every sample; however, carbonaceous material is here sporadic; ostracodes are still present. Inoceramus prisms and echinoid spines increase in abundance, whereas bivalve fragments, miliolids, aptychi, and other components are rare.

The Valanginian interval of Unit VI (Cores 416A-15 through 416A-36) records an increase in the rate of accumulation and a corresponding influx in biogenic material (see site chapter, this volume, for accumulation rates). The magnitude of the change shown in Figure 8 is in part artificial, because the more fossiliferous basal sandstones of the turbidite cycle were sampled more commonly than the brownish mudstones containing the autochthonous deep-sea association. Nevertheless, differences in the biogenic content are apparent between samples from Units VI and VII when comparing samples of similar lithology. Displaced foraminifers now dominate the samples, together with fish debris, fecal pellets, calcisphaerulids, and carbonaceous material. Samples are also typified by Inoceramus prisms, echinoid spines, ostracodes, aptychi, miliolids, and glauconite. Calpionellids are sporadic as detrital particles, as are pyritized burrow fillings and Chondrites. This evidence of bioturbation is found in the laminated siltstones, fine sandstones, and brownish sandstones, but is not found in the calcareous sandstones.

Cores 416A-7 to 416A-14 of Unit VI record a decrease in shallow-water influence. Samples continue to be dominated by shallow-water foraminifers, fish debris, and carbonaceous material, whereas the other components are sporadic.

Unit V (Cores 416A-5 and 416A-6), of Albian-Cenomanian age, is distinct from the underlying units in its biogenic content. With the exception of Section 416A-6, CC, deep-sea foraminifers dominate the samples. The remaining components include fish debris, pyrite, carbonaceous material, and glauconite, with rare fecal pellets and sponge spicules. This association attests the results of hemipelagic sedimentation and a greatly lessened contribution by extremely distal turbidites.

\section{Effects of Sedimentation}

Resedimentation processes exerted a strong effect on the association of biogenic and lithologic components at Site 416, as at Site 415. Differences in these associations provide evidence of both the processes involved and the environmental distribution of the enclosed fauna and flora. Two examples are shown in Figure 9; one illustrating differences in components between two turbidite cycles, the other between adjacent samples in a single cycle differentiated primarily by grain size.

The coarse basal sandstone from Section 416A-9-3 contains shallow-water foraminifers associated with heavier debris, such as fish remains, fecal pellets, pyritized foraminifers and framboids, bivalve fragments, and aptychi. Included in this mixture is lighter debris, such as ostracodes, miliolids, and carbonaceous material, as well as elements of the autochthonous assemblage such as fish debris. Deep-sea foraminifers are no doubt present, but much diluted and extremely rare in the mixed association.

Deep-sea foraminifers appear in the overlying laminated siltstone along with more-buoyant debris, such as small Inoceramus prisms, ostracodes, carbonaceous material, calcisphaerulids, and large mica flakes. The deep fauna and lightweight material is even more obvious in the upper unit of the underlying turbidite cycle. Resedimentation processes, however, are still active, as evidenced by displaced foraminifers, fecal pellets, and ostracodes.

The second example, from Section 416A-28-4, contains a redeposited assemblage with few deep-sea elements. Still, the fine sandstone shows the expected concentration of more-buoyant elements, such as ostracodes, carbonaceous material, and calcisphaerulids.

\section{Faunal Comparisons}

Jurassic sediments from Site 416 correlate in part with sediments from Hole 367 of Leg 41, drilled at a water depth of 4,748 meters, in the Cape Verde Basin; these sediments range in age from Oxfordian to Kimmeridgian, and possibly are also younger. Foraminifer assemblages described by Kuznetsova and Seibold (1978) show many similarities in content, abundance, and preservation; particularly significant are the dominance by the Spirillinacea, the composition of the agglutinated assemblage, and the diversity of the nodosariids. In contrast, radiolarians that were found in most samples at Site 367 are missing at Site 416.

A strong correlation is also made with the Valanginian at Sites 367 and 370. The fauna described from Sections $370-38$, CC, through $370-51-2$ by Kuznetsova (Kuznetsova and Seibold, 1978) is representative of the late Valanginian of Site 416 above Core 416-35. This correlation is based on the presence in both intervals of Dorothia praehauteriviana, Lenticulina ouachensis, and L. nodosa, among other species. Many similarities in composition, diversity, and preservation exist between these faunas.

At Site 120 of Leg 13 about 90 meters of Barremian to Albian sediments were recovered from Gorringe 


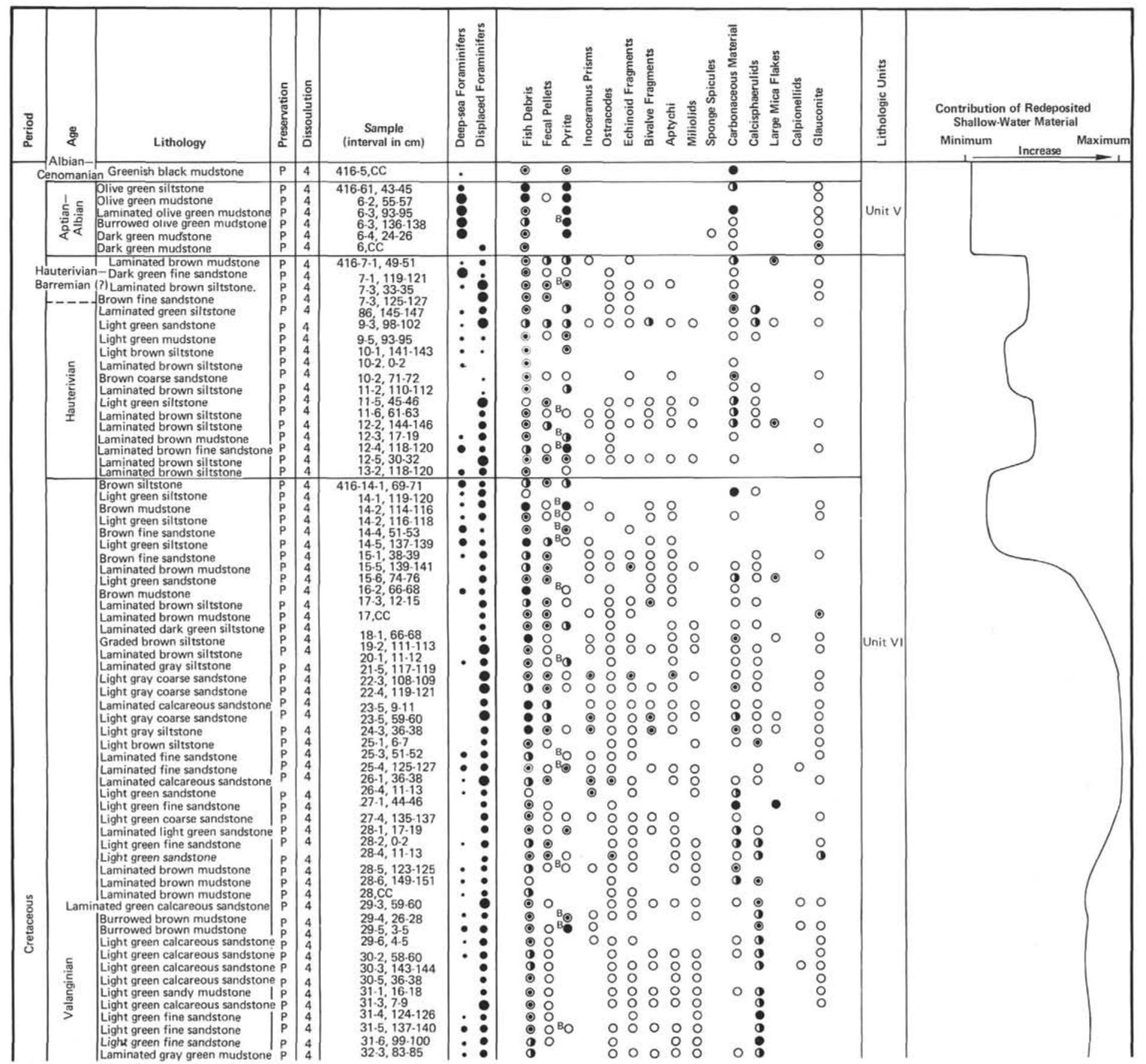




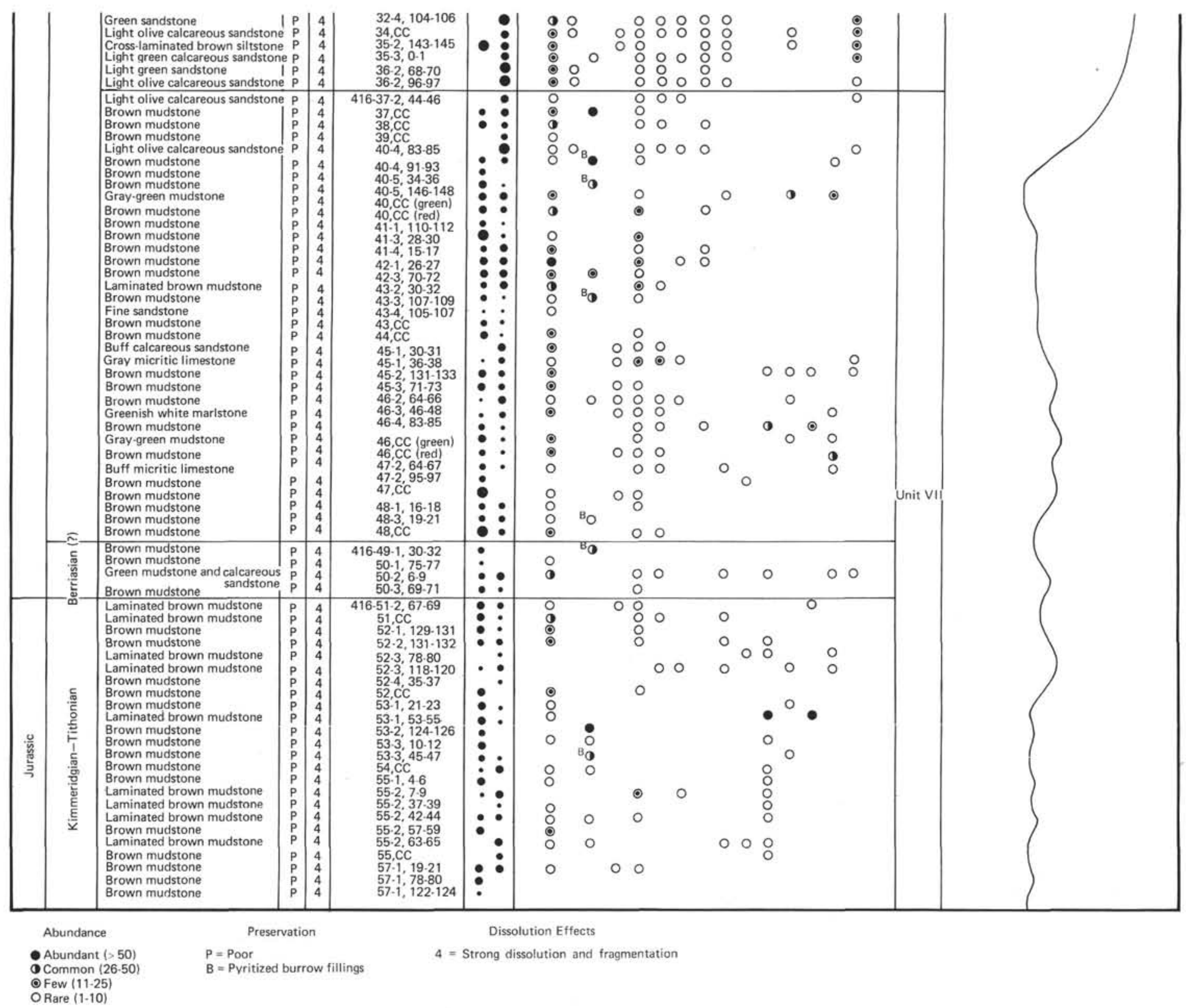

Figure 8. Distribution of selected biogenic and lithologic components at Site 416. Relative abundance of deep-sea and displaced foraminifers shown by size of symbol. Abundance of other biogenic and lithologic components based on total assemblage greater than $63 \mu \mathrm{m}$. 


\begin{tabular}{|c|c|c|c|c|c|c|c|c|c|c|c|c|c|c|c|c|c|c|c|}
\hline Hole 416A & & & & & & & & & & & & Other & omp & ents & & & & & \\
\hline Lithology & 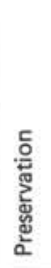 & $\begin{array}{l}\frac{5}{\stackrel{\circ}{3}} \\
\frac{3}{\circ} \\
\frac{\mathscr{m}}{0}\end{array}$ & & $\begin{array}{l}\text { Sample } \\
\text { val in } \mathrm{cm} \text { ) }\end{array}$ & 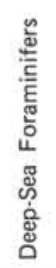 & 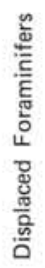 & $\begin{array}{l}\frac{n}{5} \\
\frac{5}{\Phi} \\
\frac{5}{5} \\
\frac{5}{4}\end{array}$ & 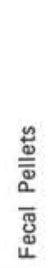 & $\stackrel{\frac{2}{2}}{2}$ & 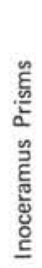 & 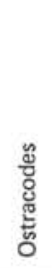 & 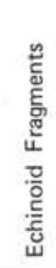 & 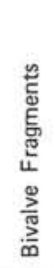 & $\begin{array}{l}\overline{5} \\
\text { Dे } \\
\frac{2}{2}\end{array}$ & $\frac{\frac{n}{0}}{\frac{0}{0}}$ & 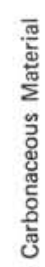 & 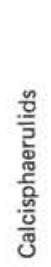 & 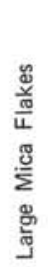 & 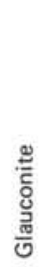 \\
\hline $\begin{array}{l}\text { Laminated brown } \\
\text { siltstone }\end{array}$ & $P$ & 4 & $\begin{array}{l}9-3 \\
9-3\end{array}$ & $\begin{array}{l}98-99 \\
99-100\end{array}$ & - & & ? & $\odot$ & & & & 0 & & & & C & $\odot$ & $\mathrm{O}$ & \\
\hline Brown coarse sandstone & $P$ & 4 & $9-3$ & $99-100$ & & & $\odot$ & & & & & & & & & & & & \\
\hline Olive green mudstone & $P$ & 4 & $9-3$ & $100-102$ & & & 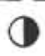 & & & & & & & & & & & & \\
\hline
\end{tabular}

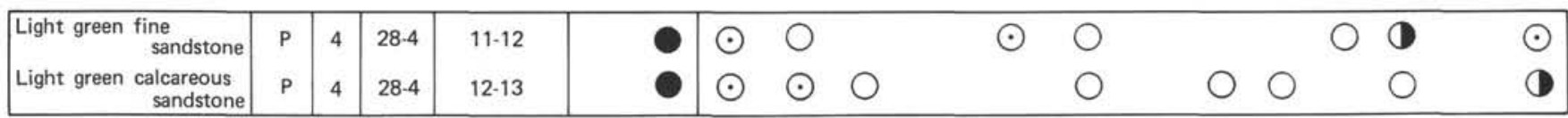

ABUNDANCE OF BIOGENIC AND LITHOLOGIC COMPONENTS

$\begin{array}{ll}\text { Abundant } & (>50) \\ \text { Common } & (26-50) \\ \text { Few } & (11-25) \\ \text { Rare } & (1-10)\end{array}$

PRESERVATION

$\mathrm{P}=$ Poor

$B=$ Pyritized burrow fillings
DISSOLUTION EFFECTS

4 = Strong dissolution and fragmentation

Figure 9. Distribution of selected biogenic and lithologic components in separate units of turbidite cycles at Site 416. Relative abundance of deep-sea and displaced foraminifers shown by size of symbol. Abundance of other biogenic and lithologic components based on total assemblage greater than $63 \mu \mathrm{m}$. Dashed line represents boundary between turbidite cycles.

Bank, off Portugal. Many of the foraminifers from this interval, described by Maync (1973) are found at Site 416. These faunal similarities indicate an approximate correlation between Cores 120-2 through 120-7 and Section 416A-5, CC through Core 416A-8. Although most of the species are long ranging or of uncertain stratigraphic value, the presence of Lenticulina ouachensis ouachensis, L. ouachensis multicella, L. praegaultina, Marssonella hauteriviana (= Dorothia hauteriviana), and Hedbergella sp. cf. $H$. infracretacea provides a broad stratigraphic framework within which to correlate.

In the western Atlantic, sediments penetrated in Holes 100, 101, and 105 of Leg 11 show close correspondence to those of Hole $416 \mathrm{~A}$, in both foraminifer assemblage and depositional environment. At Site 100, in the Blake-Bahama Abyssal Plain, several species from the Late Jurassic sequence described by Luterbacher (1972) correspond to species in the Hole 416A assemblage, notably Bigenerina jurassica, Trocholina transversarii (= Trocholina conica), and species of Dentalina, among others. The Site 100 section thus correlates in part with Cores 416A-51 through 416A-57 and possibly with sediment as young as Core $416 \mathrm{~A}-49$.

Neocomian sediments of Site 101, adjacent to Site 100 , contain a low-diversity fauna that includes Dorothia praehauteriviana. This sequence correlates with the upper-Valanginian sediments of Site 416.

The most-complete correlations in the western Atlantic are made with sediments penetrated in Hole 105, on the Hatteras Abyssal Plain. Foraminifers described by Luterbacher (1972) range in age from KimmeridgianOxfordian(?) to late Albian or early Cenomanian. Comparison of the faunal lists shows at least 27 species in common with the fauna of Hole 416, in addition to strong similarities in generic composition, foraminiferal abundance, and preservation. Species which are present in sediments of Holes 105 and 416 include Reophax helveticus, Dentalina jurensis, and Brotzenia sp. aff. $B$. uhligi (= Epistomina uhligi) in the Late Jurassic sequence; Dorothia praehauteriviana, Lenticulina nodo$s a$, and $L$. subalata in the Valanginian; and Lenticulina ouachensis ouachensis and $L$. ouachensis multicella in beds referred to the upper Valanginian and Hauterivian in Hole 105.

Depositional environments of the western Atlantic sites are bathyal to deep bathyal, but probably not abyssal, according to Luterbacher (1972). The present study supports these earlier interpretations. Although it is difficult at this time to make exact comparisons between the western sites and Site 416 , several differences do exist. Sediments from Jurassic and Neocomian sections of the western sites are richer in argillaceous limestone and calcareous mudstone. Radiolarians are present in most of the western samples, but are missing at Site 416. Foraminifer assemblages from the Jurassic of Hole 105 are enriched in miliolids and other shallowwater species. These differences may indicate somewhat shallower water depths for the western sites, although the evidence is far from conclusive. Upwelling along the 
eastern margin of the Atlantic off the African Coast during the Mesozoic, a not-improbable occurrence, presumably would raise the level of red-mudstone deposition to depths shallower than those at Site 105. In addition, the enrichment in shallow-water species at Site 105 could plausibly reflect the effectiveness of traction flows and bottom currents in compounding the hazards of paleoenvironmental interpretation.

\section{BATHYMETRY OF JURASSIC AND EARLY CRETACEOUS FORAMINIFERS}

Two foraminiferal assemblages are clearly distinguished in the Upper Jurassic and Neocomian sediments of Hole 416A: a deep-sea assemblage and a neritic assemblage. What remain to be defined are (1) the water depths of the deep-sea assemblage and (2) which foraminifers represent slope environments. Some preliminary answers to these questions can be made on the basis of present faunal distributions. The deep-sea assemblage is believed to represent lower-bathyal to abyssal water depths of $\mathbf{2 0 0 0}$ meters or more. Several lines of evidence support this hypothesis: the relationship of the Site 416 fauna to other faunas, notably those of Leg 11; the lithology; and the tectonic history of the region since the opening of the North Atlantic. The strongest support, however, comes from the fauna itself and its similarity to assemblages in deep-sea middleCretaceous sediments such as those of Hole 415A. In these Albian and Cenomanian deposits, a distinct differentiation of shelf, slope, and deep-water assemblages provides a basis for interpretation of the bathymetric range of the deep-water assemblages. The foraminifers that constitute these deep-water assemblages are nearly identical generically - and often specifically to those from the Upper Jurassic and Lower Cretaceous at Site 416. The two assemblages contain such genera as Bigenerina, Glomospira, Glomospirella, Haplophragmoides, Hippocrepina, Hyperammina, Rhizammina, Lituotuba, Psammosphaera, Recurvoides, Reophax, Saccammina, and Spiroplectammina. On the basis of this correspondence, the bathymetric range of the Late Jurassic and Early Cretaceous assemblages is assumed to be similar to that of the middle Cretaceous.

Jurassic and Neocomian faunal assemblages of the continental slopes are more difficult to interpret. Certainly, neritic assemblages are well known from various latitudes, as noted for the Jurassic by Gordon (1970). These assemblages are rich in nodosariids, polymorphinids, epistominids, and miliolids such as Ophthalmidium and Spiroloculina. Agglutinated species are dominated by forms with simple walls in high latitudes and by those with complex internal structures in low latitudes. Slope fauna assemblages apparently were similar to those of shelf environments. It is this similarity, compounded by a lack of publication on foraminifers from slope environments of the Jurassic through the Neocomian, that remains the primary obstacle to interpretation. However, some information, such as the paper by Farinacci (1965) on bathyal foraminifers from Upper Jurassic marl and limestone of the central Apen- nines, does exist. This fauna is dominated by Spirillina, Turrispirillina, and Lenticulina; the remaining species belong to the Nodosariacea. Notably missing are agglutinated forms and species of Frondicularia, Saracenaria, and Epistomina.

At Site 416 , foraminifers from slope environments are most apparent in the green siltstones of Neocomian age. These siltstones, which overlie sandstones at the bases of turbidite cycles, presumably represent a mixture of materials incorporated during sediment transport. The slope species are more easily observed, owing to the lack of dilution by coarser shelf debris that is associated with the sandstones. Elements of the slope assemblage are recognized by comparison of faunal distribution (Appendix 3) and lithology (Figure 8); faunal generalizations are made for each major lithology by identifying the dominant species in each sample and subsequently ranking them from most to least common according to lithology. Accordingly, the brown mudstones are dominated by Hyperammina gaultina, followed by Trochammina quinqueloba, Glomospirella gaultina, Rhizammina indivisa, Haplophragmoides concavus, Dentalina communis, and so on. For the coarse, commonly calcareous sandstones, the dominant species is Spirillina minima, followed by $S$. tenuissima, Dentalina communis, Lenticulina muensteri, Ophthalmidium spp., Lenticulina subalata, Trocholina infragranulata, and others. In contrast, the green siltstones are dominated by Lenticulina muensteri, Spirillina tenuissima, Dentalina communis, Dorothia hauteriviana, Hyperammina gaultina, and others. Because of these correlations, slope assemblages at Site 416 are believed to include such species as Dentalina communis, Lenticulina subalata, L. praegaultina, L. muensteri, Astacolus incurvatus, Dorothia hauteriviana, D. kummi, D. filiformis, Textularia cordiformis, Spirillina tenuissima, and Pseudonodosaria humilis. Of course, resedimentation processes have exerted a strong influence on the faunal composition of each lithology; nevertheless, some faunal differences, which are believed to reflect original environments of deposition, are apparent.

The low-diversity Jurassic and Neocomian slope faunas indicate weak stratification of the middle-depth waters in the North Atlantic, at least to the CCD. In fact, a well-defined slope assemblage does not appear until the middle Cretaceous with the evolution of such characteristic genera as Globorotalites, Neobulimina, Eouvigerina, Pyramidina, and Quadrimorphina (Sliter, 1972). It is believed that the middle-Cretaceous niche partitioning of slope environments was caused by intensified stratification of middle-depth waters. Certainly the geotectonic evolution of the North Atlantic exerted a strong influence on biotic evolution. Changes in the composition of foraminiferal assemblages from slope environments appear to have begun during the Barremian (between 120 and $115 \mathrm{Ma}$ ). By Aptian or Albian time (around $110 \mathrm{Ma}$ ), slope faunas were well defined. These faunal changes parallel several events that took place in the evolution of the North Atlantic. According to the reconstructions of Sclater and others (1977), the 
North Atlantic was probably opened to surface flow from the Tethys Sea about $150 \mathrm{Ma}$. Exchange with the Pacific was likely, because the gap between the Bahamas platform and the Guinea nose is large. Whether this exchange involved shallow waters only or mid-depth and deep water must have depended on the configuration of the still poorly understood Caribbean island-arc system. By $110 \mathrm{Ma}$, both deep and shallow waters could have entered the North Atlantic from the Tethys Sea; however, deep flow from the Pacific is problematical. Between 110 and $95 \mathrm{Ma}$, it is likely that both deep and shallow waters entered from the Tethys Sea, but exchange with the Pacific is still problematical. Despite these uncertainties, changes that appear in the Barremian and Albian slope faunas reflect changes in middledepth waters of the world's oceans at a time when exchange between the North Atlantic, the Tethys Sea, and the Pacific was established.

\section{TAXONOMIC NOTES}

Original designations of the species identified in samples from Leg 50 are listed in Appendix 1.

\section{Rhizammina indivisa Brady}

(Plate 1, Figure 1)

Fragments of Rhizammina are differentiated from those of Hyperammina gaultina ten Dam (Plate 1, Figures 4-6) by their larger size, coarser agglutinated material, and reduction in cement that produces a rougher surface. None of the fragments so identified have the bulbous proloculus that identifies the genus Hyperammina.

\section{Glomospirella gaultina (Berthelin)}

(Plate 1, Figures 11-13)

Glomospirella is distinguished from Ammodiscus by the initial irregular coil and later common overlapping coiling pattern. Specimens from the late-Valanginian samples of Site 416 sometimes develop a distinct neck and occasional nodes on the outer periphery, as shown in Figure 13. Although these specimens may prove to represent a distinct taxon, they are included here in the present species.

\section{Reophax sp.}

Several small, poorly preserved specimens with coarse wall material and indistinct sutures were found in Sample 416A-55-1, 4-6 cm. They most clearly resemble Reophax multilocularis, but differ in the lack of chamber differentiation as illustrated by Haeusler (1890). The specimens are $0.7 \mathrm{~mm}$ wide and up to $0.3 \mathrm{~mm}$ in length.

\section{Ammobaculites euides Loeblich and Tappan}

(Plate 2, Figures 10-12)

Considerable variation in test length-width ratios and prominence of the initial coil is found in intergrading populations at Site 416, as shown in Figures 10-12. Typically the species is recognized by the diameter of the initial coil, which generally is greater than in the rectilinear portion, by distinct sutures, and by a lobate periphery.

\section{Ammobaculites irregularis (Gümbel)}

(Plate 2, Figures 13-14)

Specimens referred to this variable species are characterized by a small initial coil, gradually flowing rectilinear portion of the test, indistinct sutures, and smooth to gently lobate periphery. The wall is finely agglutinated, and specimens are commonly compressed.

Spiroplectammina sp. cf. S. obscura Said and Barakat

A single poorly preserved specimen in Sample 416A-40-4, 83-85 $\mathrm{cm}$ is tentatively referred to this Cretaceous species. The test is broadly flaring, rounded in cross section, with indistinct chambers and initial coil. Length is $0.3 \mathrm{~mm}$, width $0.2 \mathrm{~mm}$.

\section{Bigenerina clavellata Loeblich and Tappan}

(Plate 3, Figures 6-7)

This species is recognized by the reduced initial, biserial portion of the test, and by globular chambers that increase rapidly in size, causing the rectilinear portion of the test to flare.

\section{Bigenerina jurassica (Haeusler) \\ (Plate 3, Figures 8-10)}

Jurassic specimens referred to this species agree closely with the original description of Haeusler (1890). Specimens show considerable variation in test dimensions, but differ from Bigenerina clavellata in the less-flaring test, less-globular chambers, and more distinct early, biserial portion of the test. Sides of elongate specimens are nearly parallel and tests are compressed and commonly deformed.

Dorothia hauteriviana (Moullade)

(Plate 4, Figure 19; Plate 5, Figures 1-4)

An elongate-conical test with flush sutures and flattened apertural face characterizes this species. Wall material in the present specimens is composed of coccolith debris, with minor amounts of silica, iron, and aluminum, as shown in Plate 5, Figure 2. An occasional specimen shows a rounded outline and slightly depressed sutures (Plate 5 , Figure 4). For the present, these individuals are included in the present species.

\section{Dorothia praehauteriviana Dieni and Massari}

(Plate 5, Figures 7-9)

This species is differentiated from Dorothia hauteriviana by its less-tapered initial portion and less-flaring test. Sutures are slightly depressed, the periphery is gently lobate, and the apertural face is nearly horizontal. Thus, the species agrees closely with the original description of Dieni and Massari (1966). At Site 416, D. praehauteriviana ranges from the upper Valanginian to lower Hauterivian, where it overlaps with the Hauterivian-Barremian species $D$. hauteriviana.

\section{Nodosaria sp. cf. N. chapmani Tappan}

(Plate 5, Figure 19)

The illustrated specimen is referred to this species, although it differs somewhat in having less-elongate chambers and more-numerous longitudinal costae.

\section{Astacolus incurvatus (Reuss)}

(Plate 6, Figures 11-12)

Specimens with an elongate, compressed test, having a pointed or rounded initial portion of the test with elongate, narrow, oblique chambers are included in this species. Considerable variation is noted between the two specimens figured on Plate 6 .

\section{Dentalina nana Reuss \\ (Plate 7, Figures 5-6)}

This is a variable species, as shown on Plate 7. The form shown in Figure 6 more closely typifies the species; it has a gradually tapering test and gradually enlarging chambers, of which the final one tends to become inflated.

\section{Lenticulina praegaultina Bartenstein, Bettenstaedt, and Bolli} (Plate 10, Figures 5-7, 10)

Specimens referred to this species have a distinct keel, average 10 chambers in the last-formed whorl, and have flush to slightly raised sutures, as illustrated on Plate 10. The species typically ranges from the Hauterivian to the Barremian; however, specimens at Site 416 were found in upper-Valanginian and Hauterivian sediments.

\section{Lenticulina subalata (Reuss) \\ (Plate 10, Figures 8-9, 11-16)}

A number of aberrant specimens of this species were found in Sample 416A-22-3, 108-109 cm, as shown on Plate 10. The species is typically represented by specimens with raised sutures, seven to nine chambers, and an angled to keeled periphery. 
Lenticulina sp. A

(Plate 11, Figures 6-8)

Two specimens from the upper Valanginian of Site 416 illustrated on Plate 11 have a globose test with a rounded periphery, four globular chambers in the final whorl, and slightly depressed sutures.

Lenticulina sp. B

(Plate 11, Figure 9)

Several specimens from the Hauterivian section of Site 416 have a compressed test, 10 to 11 chambers in the final whorl, and distinctly raised, limbate sutures between chambers.

Lenticulina sp. C

(Plate 11, Figures 10-11)

A single specimen from the Hauterivian of Site 416 with a compressed test, evolute coiling pattern, 10 chambers in the final whorl, and slightly depressed sutures somewhat resembles Lenticulina sp. 2 of Bartenstein, Battenstaedt, and Bolli (1957) from the Barremian of Trinidad.

\section{Vaginulinopsis sp. A}

(Plate 13, Figure 6)

A single poorly preserved specimen from the lower Valanginian at Site 416 has an elongate test with a triangular section, numerous chambers that increase gradually in size, and oblique, flush sutures.

Vaginulinopsis sp. B

(Plate 13, Figures 7-8)

Several typical specimens from the lower Valanginian of Site 416 are shown on Plate 13. The test is much compressed, with an initial coiled portion followed by chambers that increase in width more rapidly than in height, producing the characteristic shape with overhanging chambers.

\section{Vaginulinopsis sp. C}

(Plate 13, Figure 9)

This species is represented by a single poorly preserved specimen from the lower Valanginian of Site 416. The test is elongate and gently arcuate, with strongly oblique sutures and some evidence of longitudinal costae. These characteristics are similar to those of the specimen illustrated as Vaginulina sp. 3 by Bartenstein and Brand (1951).

\section{Vaginulinopsis sp. D \\ (Plate 13, Figure 10)}

A single specimen from the upper Valanginian of Site 416 has an arcuate test that is distinctly triangular in cross section, numerous chambers that increase gradually in size, and slightly depressed sutures.

Lingulina sp.

(Plate 13, Figure 16)

Several specimens of this species were found in the Valanginian of Site 416. These are conical, with a globular final chamber, indistinct sutures, and a terminal, elongate, slit-like aperture. These specimens appear to be related to the specimen illustrated by Bartenstein and Brand (1951) as Lingulina sp. 3.

\section{Tristix lanceola Sliter, n. sp. \\ (Plate 14, Figures 10-18)}

Test free, uniserial, flaring in outline, unevenly quadrate in section, so that width is greater than thickness. Chambers 7 to 8 arcuate, increasing gradually in height, final chamber commonly narrower than maximum width of test. Sutures distinct, slightly depressed, gently curved. Wall calcareous, finely perforate. Aperture terminal, consisting of an irregular series of small pores elongate in plane of compression.

Dimensions of holotype: Length $180 \mu \mathrm{m}$, width $120 \mu \mathrm{m}$. (Paratypes range from 165 to $180 \mu \mathrm{m}$ in length.)

Locality: Holotype from DSDP Leg 50, Site 416, Sample 416A-17-3, 12-15 cm. Paratypes from Sample 416A-12-5, 30-35 cm.,
416A-17-3, 12-15 cm., and 416A-30-3, 143-144 cm. Moroccan Basin, North Atlantic Ocean (lat. $32^{\circ} 50.18^{\prime}$ N., long. $10^{\circ} 48.06^{\prime} \mathrm{W}$.).

Stratigraphic range: Upper Valanginian and lower Hauterivian.

Remarks: This small species of characteristic quadrate shape is a rare but consistent component of the Valanginian and Hauterivian sediments at Site 416. Morphologic variations are minor and consist of slight changes in the degree of test flare and shape of the final chamber.

Holotype (USNM 252178) and paratypes (USNM 252179, 252180, 252498) are deposited in the U.S. National Museum of Natural History, Washington, D.C.

\section{Schackoina multispinata (Cushman and Wickenden)}

(Plate 17, Figures 5-7, 9)

Specimens included here in multispinata include both the bicornis and moliniensis forms of Reichel (1948), as shown in Figures 7 and 9. These larger specimens were found at Site 415 in Section 415A -12, CC, to Core 415A-15, or from upper Albian to middle Cenomanian. They are included in the species because they intergrade with smaller specimens that correspond to the typical description (Figures 5 and 6 ).

\section{Hedbergella sp. cf. H. delrioensis (Carsey)}

(Plate 17, Figures 13-16)

Numerous specimens from Site 415 , Cores $415 \mathrm{~A}-12$ to $415 \mathrm{~A}-15$ differ from the original concept of Hedbergella delrioensis and from the neotype selected by Longoria (1974) in having 5 to 7 chambers, less-globular chambers, a slightly convex to flattened spiral side, a smaller umbilicus, and a more spinose surface, as shown on Plate 17. They most closely resemble the $H$. sp. aff. delrioensis of Krasheninnikov (1974), from Albian sediments in the eastern Indian Ocean. The Leg 50 material may be related to $H$. pseudotrocoidea Michael from the Albian of Texas, but dissimilarities are apparent in the size of the final chamber, the amount of chamber inflation, and the compression of the test. Similar variations distinguish the specimens from the Aptian and Albian species $H$. gorbachikae Longoria.

Hedbergella sp.

(Plate 18, Figures 11-14)

Several specimens from Core $415 \mathrm{~A}-11$ are distinguished by their small tests, globular chambers that increase rapidly in size, small umbilicus, and unusual, oblique coiling pattern. The specimens are unrelated to other members of the population and are restricted to the middle-Cenomanian Rotalipora cushmani Zone.

\section{Genus Trocholina Paalzow}

Three species of Trocholina are recognized in the Leg 50 material. Jurassic specimens with transverse grooves of the ventral surface and few umbilical nodes are placed in Trocholina conica (Plate 20, Figures 13-14). This concept includes Trocholina transversarii Paalzow in synonymy, and the specimens are identical to those illustrated by Winter (1970). Early-Valanginian specimens with a flattened ventral surface, conical shape, and numerous umbilical nodes are referred to Trocholina valdensis (Plate 20, Figures 15-16; Plate 21, Figures 1-3). Late-Valanginian specimens are placed in Trocholina infragranulata (Plate 20, Figures 7-12). These specimens have more-numerous umbilical nodes, a less-conical shape, and a more-distinct final whorl on the ventral surface.

\section{Epistomina anterior Bartenstein and Brand}

(Plate 22, Figures 1-6)

The present specimens from the Valanginian of Site 416 agree with the original description. These differ from the Jurassic species Epistomina uhligi (Plate 22, Figures 11, 13-15) in having a moreangled periphery and being more evenly biconvex, with a moreprominent umbo on the umbilical side.

\section{Epistomina $\mathrm{sp}$.}

(Plate 22, Figures 12, 16)

A single specimen from Sample 416A-40-5, 34-36 cm is referred to Epistomina. The plano-convex shape, carinate periphery, and raised sutures on the umbilical side are distinctive. 


\section{ACKNOWLEDGMENTS}

I should like to thank the Deep Sea Drilling Project for inviting me to participate on Leg 50 aboard the Glomar Challenger. Thanks are also extended to J. A. Barron and R. Z. Poore of the USGS, who kindly read and commented upon the manuscript. I am particularly indebted to R. L. Oscarson of the USGS for operating the Cambridge S-180 scanning electron microscope and the attached EDAX energy-dispersive $\mathrm{X}$-ray analyzer, and for taking scanning electron micrographs. I am grateful to R. J. Cullip of the USGS for his help in drafting and figure preparation and to M. A. Breeden, also of the USGS, for sample preparation. Finally, I wish to thank my cruise cohorts for their scientific collaboration and the good times that made the cruise enjoyable.

\section{REFERENCES}

Bartenstein, H., Bettenstaedt, F., and Bolli, H., 1957. Die Foraminiferen der Unterkreide von Trinidad, B.W.I. 1. Teil: Cuche- und Toco-Formation. Eclogae Geologicae Helvetiae, v. 50, pp. 5-68.

Bartenstein, H., and Brand, E., 1951. Mikropalaontologische Untersuchungen zur Stratigraphie des nordwest-deutschen Valendis. Senckenbergiana Naturforschenden Gesellschaft Abhandlungen 485, pp. 239-336.

Beckmann, J. P., 1972. The Foraminifera and some associated microfossils of Sites 135 to 144. In Hayes, D. E., Pimm, A. C., et al., Initial Reports of the Deep Sea Drilling Project, v. 14: Washington (U.S. Government Printing Office), pp. $389-420$.

Dieni, I., and Massari, F., 1966. I foraminiferi del Balanginano superiore di Orosei (Sardegna). Palaeontographica Itali$a n a$, v. 61 (n. ser. 31), pp. 75-186.

Farinacci, A., 1965. I foraminiferi di un livello marnoso nei Calcari diasprigni del Malm (Monte Martani, Umbria). Geologica Romana, v. 4, pp. 229-258.

Gordon, W. A., 1970. Biogeography of Jurassic Foraminiifera. Geological Society of America Bulletin, v. 81, pp. 1689-1704.

Haeusler, R., 1890. Monographie der Foraminiferen-Fauna der schweitzerischen Transversarius-Zone. Schweizerische Palaontologische Gesellschaft Abhandlungen, v. 17, pp. 1-134.

Krasheninnikov, V. A., 1974. Cretaceous and Paleogene planktonic foraminifera, Leg 27 of the Deep Sea Drilling Project. In Veevers, J. J., Heirtzler, J. R., et al., Initial Reports of the Deep Sea Drilling Project, v. 27: Washington (U.S. Government Printing Office), pp. 663-671.

Kuznetsova, K. I., and Seibold, I., 1978. Foraminifers from the Upper Jurassic and Lower Cretaceous of the eastern Atlantic (DSDP Leg 41, Sites 367 and 370). In Lancelot, Y., and Seibold, E., et al., Initial Reports of the Deep Sea Drilling Project, v. 41: Washington (U.S. Government Printing Office), pp. 515-537.

Longoria, J. F., 1974. Stratigraphic, morphologic, and taxonomic studies of Aptian planktonic Foraminifera. Revista Espanola Micropaleontologia Special Publication, 107 pp.

Luterbacher, H., 1972. Foraminifera from the Lower Cretaceous and Upper Jurassic of the northwestern Atlantic.
In Hollister, C. D., Ewing, J. I., et al., Initial Reports of the Deep Sea Drilling Project, v. 11: Washington (U.S. Government Printing Office), pp. 561-593.

Maync, W., 1973. Lower Cretaceous foraminiferal fauna from Gorringe Bank, eastern North Atlantic. In Ryan, W. B. F., Hsü, K. J., et al., Initial Reports of the Deep Sea Drilling Project, v. 13: Washington (U.S. Government Printing Office), pp. 1075-1111.

Moullade, M., 1973. Zones de Foraminiferes du Cretace inferieur mesogeen. Comptes Rendus Hebdomadaires des Seances de l'Academie des Sciences, v. 278, ser. D, pp. 1813-1816.

Pflaumann, U., and Krasheninnikov, V. A., 1978. Early Cretaceous planktonic foraminifers from eastern North Atlantic, DSDP Leg 41. In Lancelot, Y., Seibold, E., et al., Initial Reports of the Deep Sea Drilling Project, v. 41: Washington (U.S. Government Printing Office), pp. 539564.

Porthault, B., 1974. Le Cretace superieur de la "Fosse Vocontienne" et des regions limitrophes (France Sud-Est). These Claude Bernard Universite, Lyon, v. 257.

Premoli-Silva, I., and Boersma, A., 1977. Cretaceous planktonic foraminifers - DSDP Leg 39 (South Atlantic). In Supko, P. R., Perch-Nielsen, K., et al., Initial Reports of the Deep Sea Drilling Project, v. 39: Washington (U.S. Government Printing Office), pp. 615-641.

Reichel, M., 1948. Les Hankeninides de la Scaglia et des Couches rouges (Cretace Superieur). Eclogae Geologicae Helvetiae, v. 40, pp. 391-409.

Sclater, J. G., Hillinger, S., and Tapscott, C., 1977. The paleobathymetry of the Atlantic Ocean from the Jurassic to the present. Journal of Geology, v. 85, pp. 509-552.

Sigal, J., 1979. Chronostratigraphy and ecostratigraphy of Cretaceous formations. In Ryan, W. B. F., Sibuet, J.-C., et al., Initial Reports of the Deep Sea Drilling Project, v. 47, Part 2: Washington (U.S. Government Printing Office).

Sliter, W. V., 1972. Cretaceous foraminifers - depth habitats and their origin. Nature, v. 239, pp. 514-515.

1976. Cretaceous foraminifers from the southwestern Atlantic Ocean, Leg 36, Deep Sea Drilling Project. In Barker, P., Dalziel, I. W. D., et al., Initial Reports of the Deep Sea Drilling Project, v. 36: Washington (U.S. Government Printing Office), pp. 519-573.

1977. Cretaceous benthic foraminifers from the western South Atlantic, Leg 39, Deep Sea Drilling Project. In Supko, P. R., Perch-Nielsen, K., et al., Initial Reports of the Deep Sea Drilling Project, v. 39: Washington (U.S. Government Printing Office), pp. 657-697.

Sliter, W. V., and Baker, R. A., 1972. Cretaceous bathymetric distribution of benthic foraminifers, Journal of Foraminiferal Research, v. 2, pp. 167-183.

Thierstein, H. R., 1976. Mesozoic calcareous nannoplankton biostratigraphy of marine sediments. Marine Micropaleontology, v. 1, pp. 325-362.

van Hinte, J. E., 1976. A Cretaceous time scale. American Association of Petroleum Geologists Bulletin, v. 60, pp. $498-516$.

Winter, B., 1970. Foraminiferenfaunen des Unter-Kimmeridge (Mittlerer Malm) im Franken. Erlanger Geologische Abhandlungen, v. 79, pp. 1-56. 



\section{PLATE 1}

Figure $1 \quad$ Rhizammina indivisa Brady.

Sample 416A-51-1, 19-21 cm. Scale $150 \mu \mathrm{m}$.

Figures 2, 3 Hippocrepina depressa Vasicek.

2. Sample 416A-48, CC. Scale $100 \mu \mathrm{m}$.

3. Sample 416A-51, CC. Scale $50 \mu \mathrm{m}$.

Figures 4-6 Hyperammina gaultina ten Dam.

4, 5. Sample 416A-55-1, 4-6 cm. Scale $100 \mu \mathrm{m}$.

6. Sample $416 \mathrm{~A}-55-2,42-44 \mathrm{~cm}$. Initial bulbous portion of test. Scale $30 \mu \mathrm{m}$.

Figure $7 \quad$ Saccammina lathrami Tappan.

Sample 416A-6-2, 55-57 cm. Scale $50 \mu \mathrm{m}$.

Figure 8 Ammodiscus rotalarius Loeblich and Tappan. Sample 416A-6-4, 24-26 cm. Scale $100 \mu \mathrm{m}$.

Figures 9, 10 Glomospira variabilis (Kübler and Swingli).

Sample 416A-55-1, 4-6 cm. Scale $30 \mu \mathrm{m}$.

Figures 11-13 Glomospirella gaultina (Berthelin).

Scale $60 \mu \mathrm{m}$.

11. Sample 416A-53-1, 21-23 cm.

12. Sample 416A-7-3, 33-35 cm.

13. Sample 416A-19-2, 111-113 cm. Typical of poorly preserved specimens from late Valanginian sequence of Site 416 .

Figure $14 \quad$ Reophax guttifer Brady. Sample 416A-22-32, 108-109 cm. Scale $100 \mu \mathrm{m}$.

Figures 15, 16 Reophax helveticus (Haeusler).

15. Sample 416A-55-1, 4-6 cm. Scale $50 \mu \mathrm{m}$.

16. Sample 416A-53-1, 21-23 cm. Scale $30 \mu \mathrm{m}$.

Figure 17 Reophax horridus (Schwager).

Sample 416A-42-1, 26-27. Scale $100 \mu \mathrm{m}$.

Figure $18 \quad$ Reophax minuta Tappan.

Sample 416A-8-6, 146-147 cm. Scale $30 \mu \mathrm{m}$.

Figure 19 Reophax multilocularis Haeusler.

Sample 416A-55-1, 4-6 cm. Scale $50 \mu \mathrm{m}$.

Figures 20, 21 Reophax pilulifer Brady.

Scale $100 \mu \mathrm{m}$.

20. Sample 416A-11-1, 57-59 cm.

21. Sample $416 \mathrm{~A}-48-3,19-21 \mathrm{~cm}$.

Figure $22 \quad$ Miliammina valdensis Bartenstein and Brand.

Sample 416A-47-2, 64-67 cm. Scale $60 \mu \mathrm{m}$. 


\section{PLATE 1}
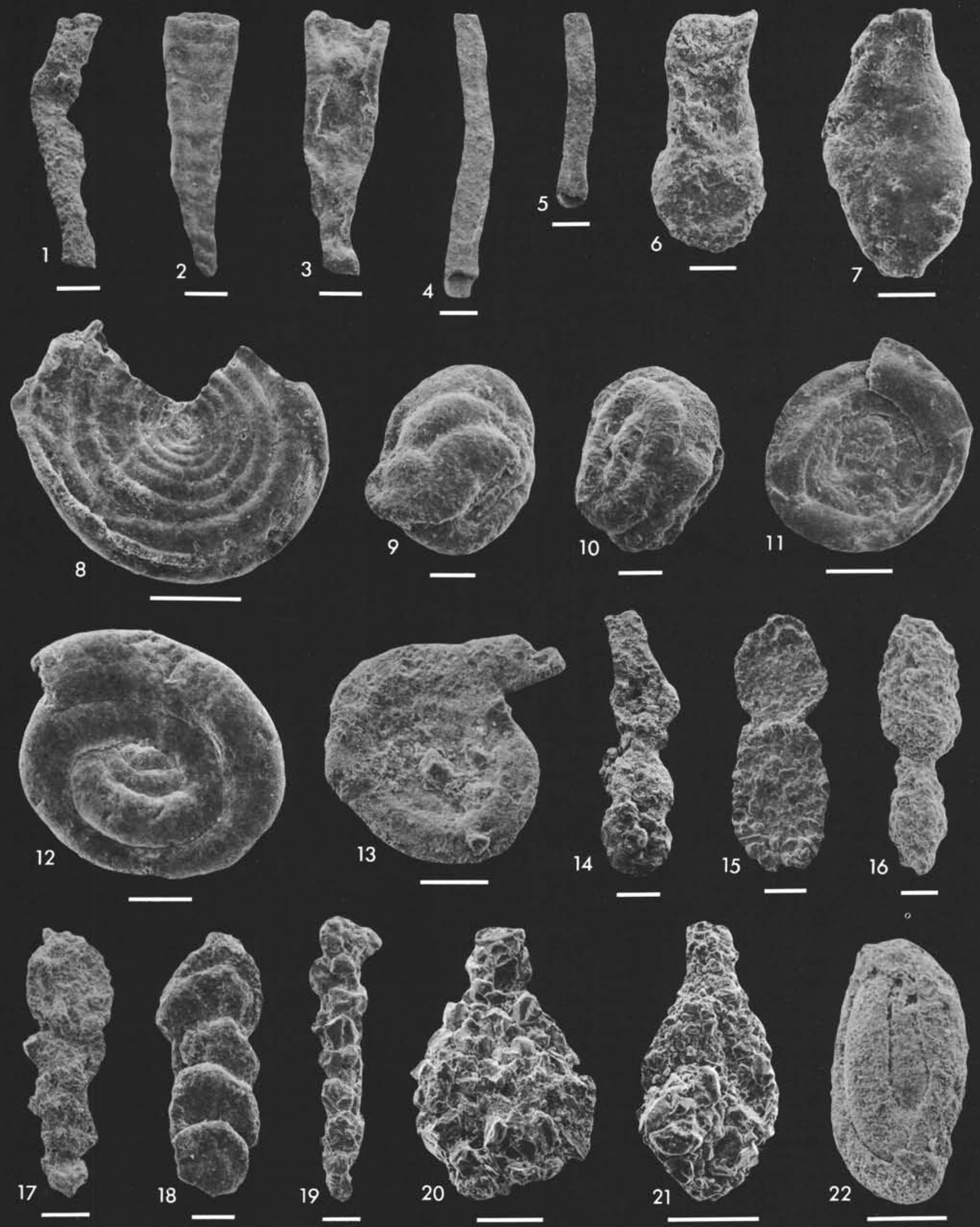


\section{PLATE 2}

Figures 1-3 Haplophragmoides concavus (Chapman).

1,2 . Side and peripheral view of same specimen. Sample 416A-41-4, 15-17 cm. Scale $100 \mu \mathrm{m}$.

3. Side view. Sample $416 \mathrm{~A}-7-1,119-121 \mathrm{~cm}$. Scale $60 \mu \mathrm{m}$.

Figure $4 \quad$ Haplophragmoides haeusleri Lloyd.

Side view of distorted specimen. Sample 416A$53-3,10-12 \mathrm{~cm}$. Scale $100 \mu \mathrm{m}$.

Figures 5, 6 Haplophragmoides nonioninoides (Reuss).

Sample 416A-6-4, 24-26 cm. Scale $100 \mu \mathrm{m}$.

5. Side view.

6. Peripheral view of same specimen.

Figures 7, 8 Recurvoides imperfectus (Hanzlikova).

Scale $100 \mu \mathrm{m}$.

7. Side view showing areal aperture and bordering lip. Sample 416A-6-4, 24-26 cm.

8. Side view of distorted specimen. Sample $416-11-1,57-59 \mathrm{~cm}$.

Figure 9 Ammobaculites $\mathrm{cf}$. A. cuyleri Tappan.

Fragment of rectilinear portion of test. Sample $416 \mathrm{~A}-6-2,93-95 \mathrm{~cm}$. Scale $100 \mu \mathrm{m}$.

Figures 10-12 Ammobaculites euides Loeblich and Tappan.

Scale $100 \mu \mathrm{m}$.

10 , 11. Sample 416A-11-1, 57-59 cm.

12. Sample $416 \mathrm{~A}-12-5,30-32 \mathrm{~cm}$.

Figures 13, 14 Ammobaculites irregularis (Gümbel).

Scale $100 \mu \mathrm{m}$.

13. Sample 416A-51, CC.

14. Sample 416A-52-3, $118-120 \mathrm{~cm}$.

Figures 15, 16 Ammobaculites suprajurassicus (Schwager).

Scale $30 \mu \mathrm{m}$.

15. Sample 416A-55-1, 4-6 cm.

16. Sample $416 \mathrm{~A}-29-5,3-5 \mathrm{~cm}$.

Figures 17, 18 Haplophragmium aequale (Roemer).

Side views. Sample 416A-53-2, 7-9 cm. Scale 100 $\mu \mathrm{m}$.

Figures 19, 20 Haplophragmium inconstans erectum Bartenstein and Brand.

19. Side View. Sample 416A-47, CC. Scale 100 $\mu \mathrm{m}$.

20. Side view. Sample 416 A-55-1, 4-6 cm. Scale $60 \mu \mathrm{m}$. 


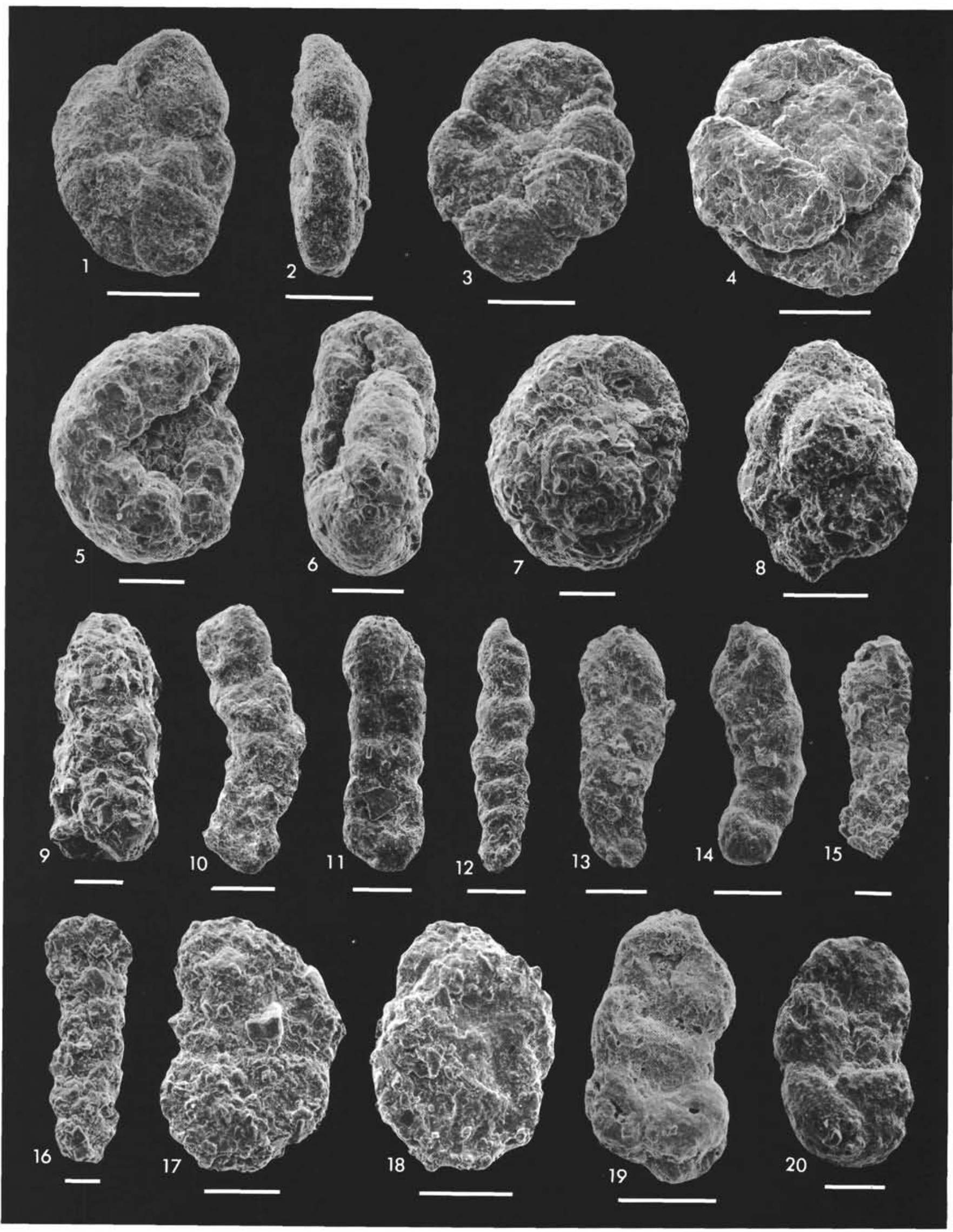




\section{PLATE 3}

Figures 1, $5 \quad$ Spiroplectammina ammovitrea Tappan.

Scale $60 \mu \mathrm{m}$.

1. Side view showing distinct initial coil. Sample 416A-6-2, 24-26 cm.

5. Fragment of rectilinear portion of test. Sample 416A-6-2, 93-95 cm.

Figure 2 Spiroplectammina longa Lalicker. Side view. Sample 416A-6-2, 55-57 cm. Scale 60 $\mu \mathrm{m}$.

Figures 3, 4 Textularia cordiformis Schwager.

Scale $60 \mu \mathrm{m}$.

3. Side view. Sample 416A-53-2, 7-9 cm.

4. Side view. Sample 416A-55-2, 42-44 cm.

Figures 6,7 Bigenerina clavellata Loeblich and Tappan.

6. Side view. Sample 416A-47, CC. Scale $30 \mu \mathrm{m}$.

7. Side view. Sample $416 \mathrm{~A}-42-1,26-27 \mathrm{~cm}$. Scale $50 \mu \mathrm{m}$.

Figures 8-10 Bigenerina jurassica (Haeusler).

Sample 416A-55-1, 4-6 cm.

8. Side view. Scale $30 \mu \mathrm{m}$.

9. Side view. Scale $30 \mu \mathrm{m}$.

10. Side view of elongate specimen. Scale $50 \mu \mathrm{m}$.

Figures 11, 15 Trochammina depressa Lozo.

Sample 416A-14-1, 69-71 cm. Scale $60 \mu \mathrm{m}$.

11. Spiral view.

15. Umbilical view.

Figures 12-14 Trochammina neocomiana Mjatliuk.

Scale $60 \mu \mathrm{m}$.

12. Spiral view. Sample 416A-53-3, 10-12 cm.

13. Peripheral view, same specimen.

14. Spiral view. Sample 416A-53-3, $45-47 \mathrm{~cm}$.

Figures 16-19 Trochammina quinqueloba Geroch.

Scale $60 \mu \mathrm{m}$.

16. Umbilical view. Sample 416A-53-2, $124-126 \mathrm{~cm}$.

17. Peripheral view. Sample 416A-53-2, $124-126 \mathrm{~cm}$.

18. Spiral view. Sample 416A-35-2, 143-145 cm.

19. Umbilical view. Sample 416A-47, CC. 


\section{PLATE 3}
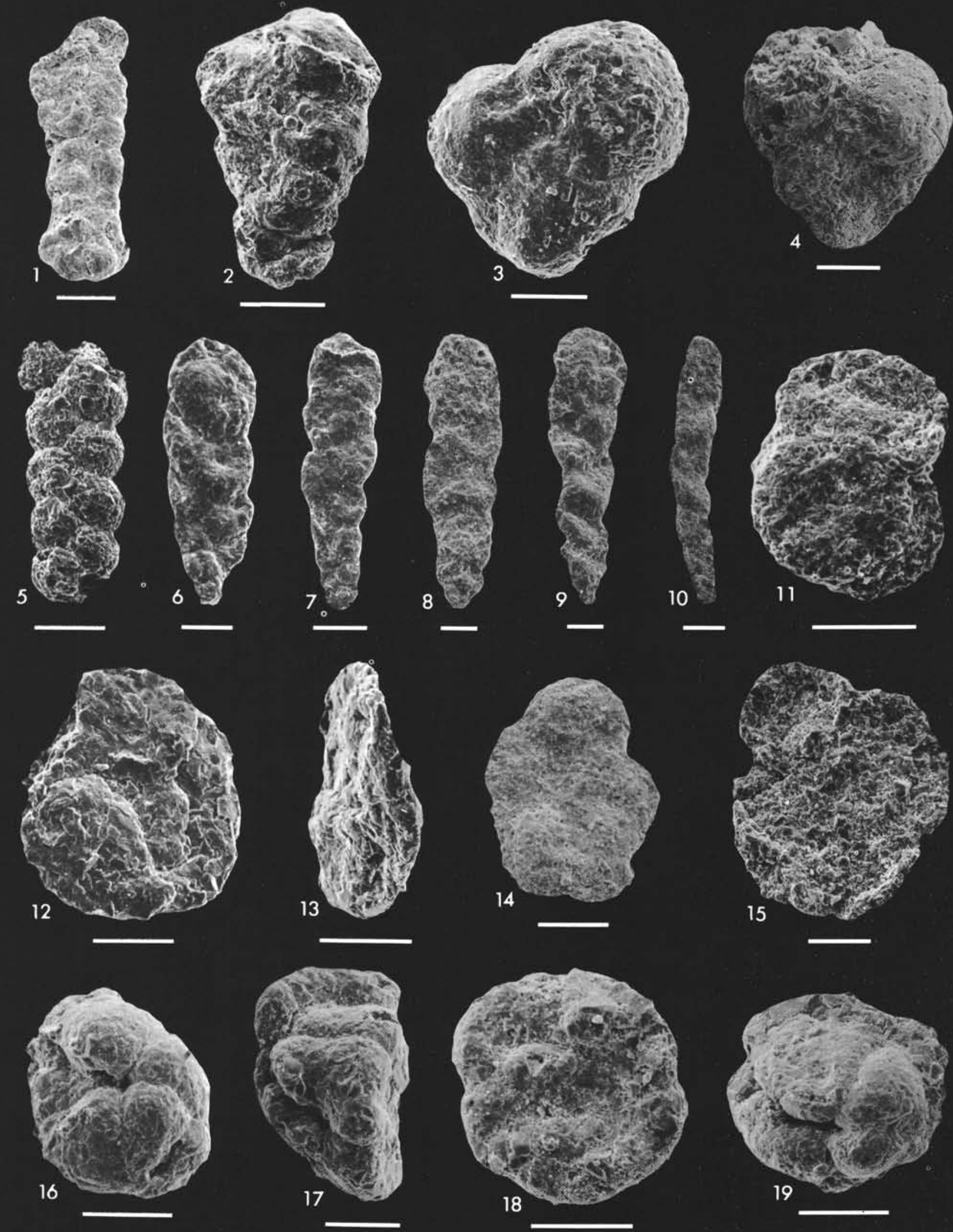


\section{PLATE 4}

Figures 1, 2, Trochammina umiatensis Tappan.

6, 7 Sample 416A-6-2, 24-26 cm. Scale $60 \mu \mathrm{m}$.

1. Spiral view.

2. Peripheral view.

6. Spiral view.

7. Umbilical view.

Figures 3-5 Trochammina suprajurassica Seibold.

3. Spiral view. Sample 416A-53-3, 10-12 cm. Scale $60 \mu \mathrm{m}$.

4. Peripheral view. Sample 416A-53-3, 10-12 $\mathrm{cm}$. Scale $60 \mu \mathrm{m}$.

5. Spiral view. Sample 416A-55-1, 4-6 cm. Scale $50 \mu \mathrm{m}$.

Figure $8 \quad$ Gaudryina grandis (Crespin).

Sample 416A-47, CC. Scale $60 \mu \mathrm{m}$.

Figures 9-11 Gaudryina neocomiensis (Mjatliuk).

9. Sample $416 \mathrm{~A}-55-2,7-9 \mathrm{~cm}$. Scale $30 \mu \mathrm{m}$.

10. Sample 416A-14-1, 69-71 cm. Scale $50 \mu \mathrm{m}$.

11. Sample 416A-53-3, 10-12. Scale $30 \mu \mathrm{m}$.

Figures 12-14 Tritaxia subrotunda ten Dam.

Sample 416A-22-3, 108-109 cm. Scale $100 \mu \mathrm{m}$.

12. Triserial initial portion.

13. Triserial initial portion.

14. Test with portion of uniserial growth stage.

Figures 15-17 Dorothia conula (Reuss).

Scale 100 um.

15. Side view. Sample 416A-25-3, 51-52 cm.

16. Side view. Sample $416 \mathrm{~A}-25-3,51-52 \mathrm{~cm}$.

17. Peripheral view. Sample 416A-12-5, 30-32.

Figure $18 \quad$ Dorothia filiformis (Berthelin).

Sample 416A-15-1, 38-39 cm. Scale $100 \mu \mathrm{m}$.

Figure 19 Dorothia hauteriviana (Moullade).

Sample 416A-12-3, 17-19 cm. Scale $100 \mu \mathrm{m}$. 

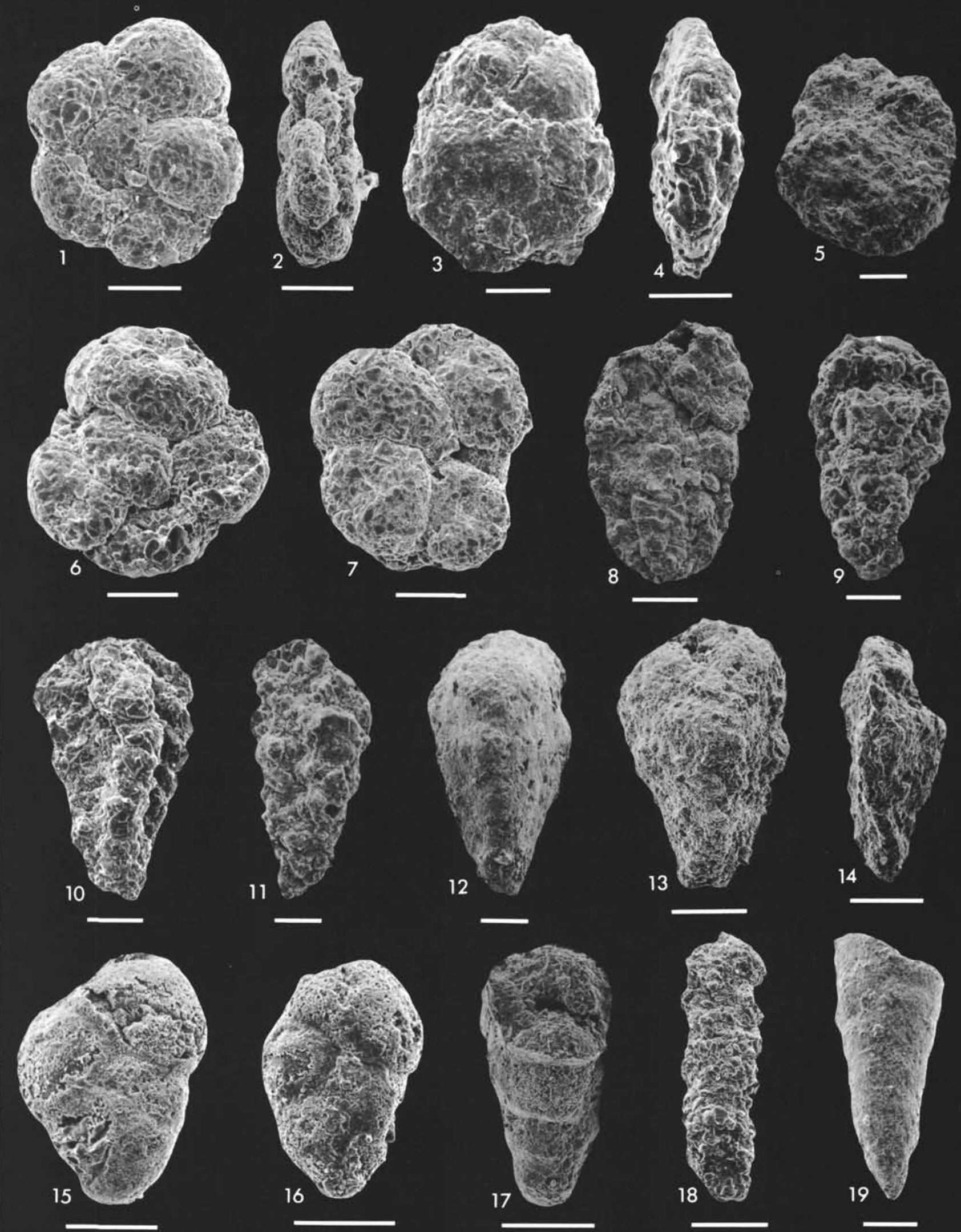


\section{PLATE 5}

Figures 1-4 Dorothia hauteriviana (Moullade).

1. Sample 416A-8-6, 146-147 cm. Scale $100 \mu \mathrm{m}$.

2. Energy-dispersive elemental X-ray spectrum of test surface of specimen in Figure 1. Note major $\mathrm{Ca}$ peak and minor $\mathrm{Si}, \mathrm{Fe}$, and $\mathrm{Al}$ peaks.

3. Enlargement of Figure 1, showing wall composed in part of corroded coccoliths. Scale $30 \mu \mathrm{m}$.

4. Sample 416A-9-3, 99-100 cm. Scale $100 \mu \mathrm{m}$.

Figures 5-6 Dorothia kummi (Zedler).

5. Sample 416A-32-4, 104-106 cm. Scale $60 \mu \mathrm{m}$.

6. Sample 416A-26-1, 36-38 cm. Scale $100 \mu \mathrm{m}$.

Figures 7-9 Dorothia praehauteriviana Dieni and Massari.

Scale $100 \mu \mathrm{m}$.

7. Sample $416 \mathrm{~A}-22-3,108-109 \mathrm{~cm}$.

8. Sample 416A-28-4, 11-13 cm.

9. Earliest representative of species at Site 416 . Carbonate-filled chambers exposed in initial portion of test. Sample 416A-32-4, 104-106 $\mathrm{cm}$.

Figures 10, 12 Ophthalmidium sp. cf. O. carinatum (Kubler and Zwingli).

Scale $100 \mu \mathrm{m}$.

10. Sample 416A-9-3, 99-100 cm.

12. Sample 416A-26-1, 36-38 cm.

Figure $11 \quad$ Spiroloculina duestensis Bartenstein and Brand. Sample 416A-26-1, 36-38 cm. Scale $100 \mu \mathrm{m}$.

Figure 13 Massilina sp. cf. M. planoconvexa Tappan. Sample 416A-22-3, 108-109 cm. Scale $100 \mu \mathrm{m}$.

Figures 14, 15 Nodobacularia nodulosa (Chapman).

14. Sample $416 \mathrm{~A}-27-1,44-46 \mathrm{~cm}$. Scale $30 \mu \mathrm{m}$.

15. Sample $416 \mathrm{~A}-19-2,111-113 \mathrm{~cm}$. Scale 100 $\mu \mathrm{m}$.

Figure 16 Triloculina meotica Loeblich and Tappan.

Sample 416A-22-3, 108-109 cm. Scale $100 \mu \mathrm{m}$.

Figures 17, 18 Nodosaria sp. cf. N. aspera Reuss.

Scale $50 \mu \mathrm{m}$.

17. Sample 416A-15-1, $38-39 \mathrm{~cm}$.

18. Sample $416 \mathrm{~A}-22-3,108-109 \mathrm{~cm}$.

Figure 19 Nodosaria sp. cf. N. chapmani Tappan.

Sample 416A-22-3, 108-109 cm. Scale $50 \mu \mathrm{m}$.

Figure $20 \quad$ Nodosaria obscura Reuss.

Sample 416A-36-2, 68-70 cm. Scale $50 \mu \mathrm{m}$.

Figure $21 \quad$ Nodosaria paupercula Reuss.

Sample $416 \mathrm{~A}-15-1,38-39 \mathrm{~cm}$. Scale $50 \mu \mathrm{m}$. 

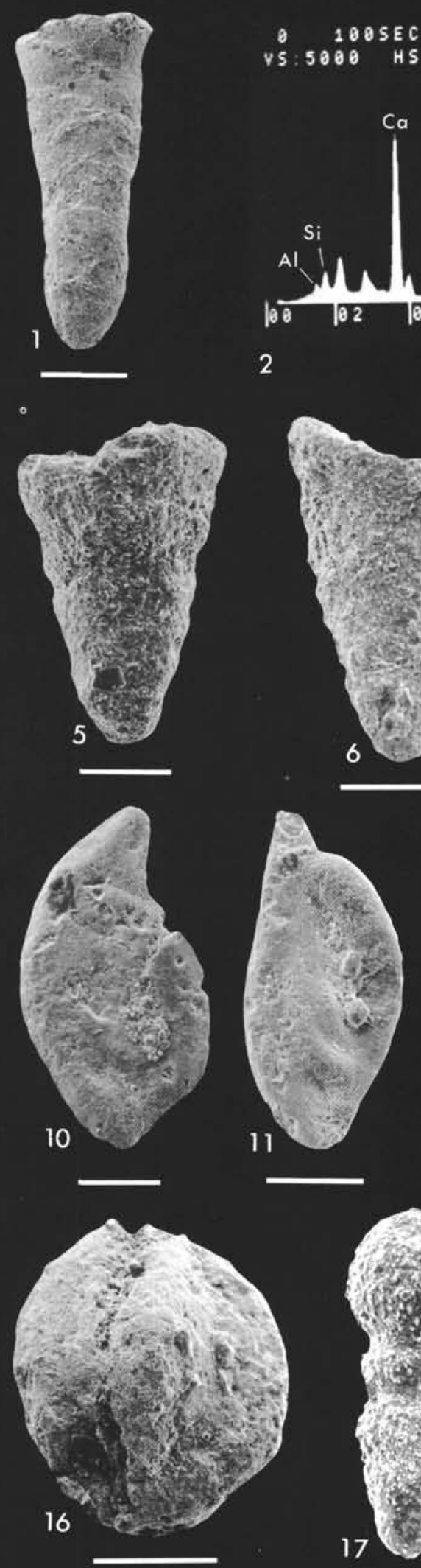
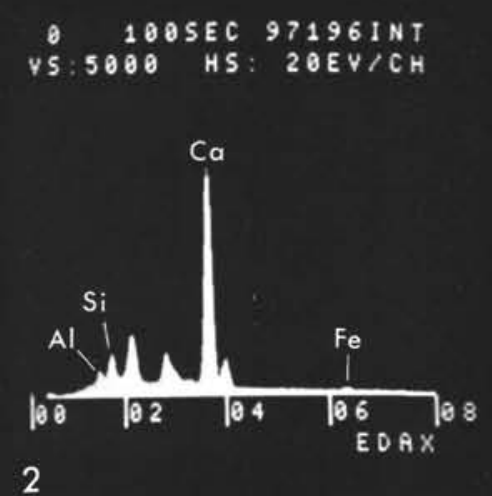
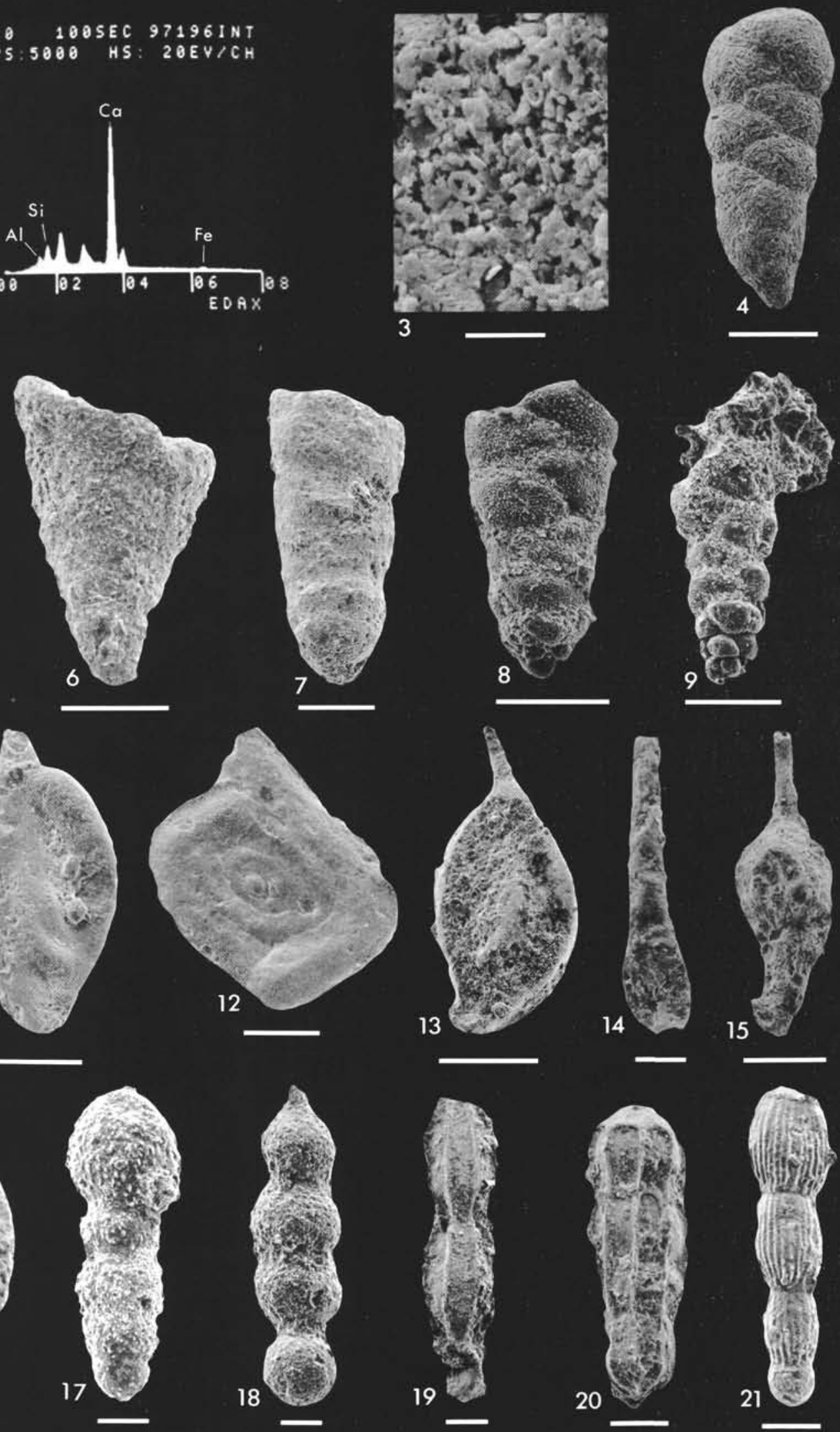


\section{PLATE 6}

Figure $1 \quad$ Nodosaria prismatica Reuss.

Sample 416A-12-2, 144-146 cm. Scale $100 \mu \mathrm{m}$.

Figure 2 Nodosaria sceptrum Reuss.

Sample 416A-31-1, 16-18 cm. Scale $100 \mu \mathrm{m}$.

Figure $3 \quad$ Nodosaria zippei Reuss.

Sample 416A-32-4, 104-106 cm. Scale $100 \mu \mathrm{m}$.

Figures 4, 5 Astacolus calliopsis (Reuss).

Sample 416A-43-2, 30-33 cm. Scale $60 \mu \mathrm{m}$.

4. Side view.

5. Face view of same specimen.

Figures 6-8 Astacolus crepidularis (Roemer).

Scale $100 \mu \mathrm{m}$.

6. Side view. Sample 416A-32-4, 104-106 cm.

7. Oblique peripheral view. Sample $416 \mathrm{~A}-17, \mathrm{CC}$.

8. Side view. Sample $416 \mathrm{~A}-7-3,125-127 \mathrm{~cm}$.

Figures 9, 10 Astacolus gratus (Reuss).

Scale $100 \mu \mathrm{m}$.

9. Side view. Sample $416 \mathrm{~A}-28-4,11-13 \mathrm{~cm}$.

10. Side view. Sample $416 \mathrm{~A}-55-2,42-44 \mathrm{~cm}$.

Figures 11, 12 Astacolus incurvatus (Reuss).

Scale $50 \mu \mathrm{m}$.

11. Side view. Sample 416A-43-2, 30-32 cm.

12. Side view of specimen with severely corroded test. Sample 416A-53-1, 21-23 cm.

Figures 13, 18 Astacolus mutilatus Espitalié and Sigal.

Sample 416A-9-3, 100-102 cm. Scale $100 \mu \mathrm{m}$.

13. Side view.

18. Side view.

Figure $14 \quad$ Astacolus planiusculus (Reuss).

Side view. Sample 416A-32-4, 104-106 cm. Scale $100 \mu \mathrm{m}$.

Figure 15 Citharina complanata peristriata Tappan.

Sample 416A-7-3, 125-127 cm. Scale $100 \mu \mathrm{m}$.

Figures 16, 17 Citharina intumescens (Reuss).

Scale $100 \mu \mathrm{m}$.

16. Side view. Sample 416A-25-4, 125-127 cm.

17. Side view. Sample $416 \mathrm{~A}-26-1,36-8 \mathrm{~cm}$.

Figures 19, 20 Dentalina communis d'Orbigny.

Scale $100 \mu \mathrm{m}$.

19. Sample 416A-28-1, $17-19 \mathrm{~cm}$.

20. Sample $416 \mathrm{~A}-15-1,38-39 \mathrm{~cm}$.

Figures 21, 22 Dentalina cylindroides Reuss.

Sample 416A-26-1, 36-38 cm. Scale $100 \mu \mathrm{m}$.

Figures 23, 24 Dentalina distincta Reuss.

23. Sample 416A-17-3, 12-15 cm. Scale $50 \mu \mathrm{m}$.

24. Sample 416A-12-5, 30-32 cm. Scale $100 \mu \mathrm{m}$.

Figure 25 Dentalina ejuncida Loeblich and Tappan.

Corroded specimen. Sample 416A-54, CC. Scale $60 \mu \mathrm{m}$. 

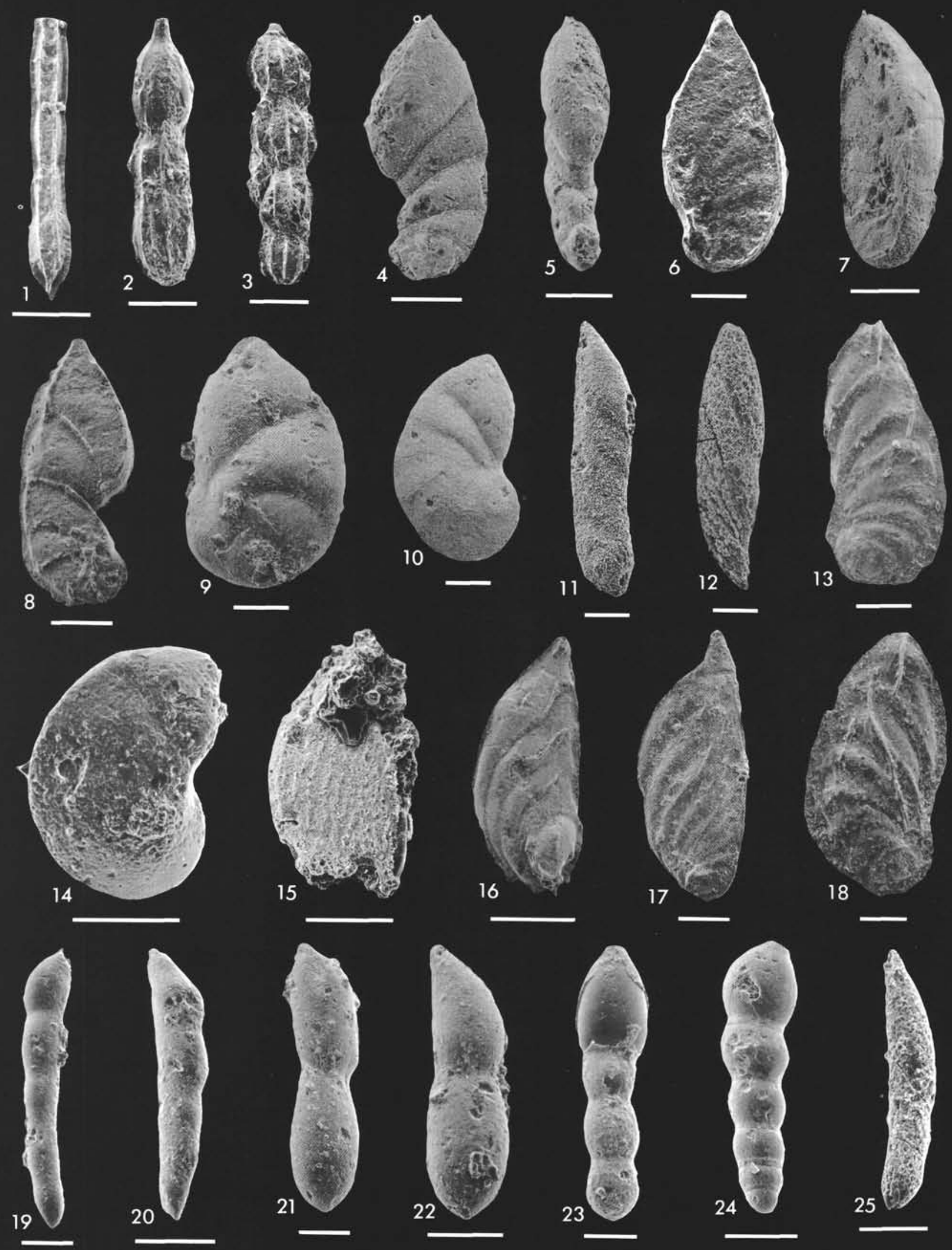


\section{PLATE 7}

Figure 1 Dentalina gracilis d'Orbigny.

Sample 416A-15-1, 38-39 cm. Scale $50 \mu \mathrm{m}$.

Figure 2 Dentalina guttifera d'Orbigny.

Sample 416A-22-3, 108-109 cm. Scale $100 \mu \mathrm{m}$.

Figure 3 Dentalina jurensis (Gümbel).

Sample 416A-55-2, 7-9 cm. Sample $50 \mu \mathrm{m}$.

Figure 4 Dentalina linearis (Roemer).

Sample 416A-46, CC. Scale $100 \mu \mathrm{m}$.

Figures 5, 6 Dentalina nana Reuss. Scale $50 \mu \mathrm{m}$.

5. Sample 416A-43-2, 30-32 cm.

6. Sample 416A-42-1, 26-27 cm.

Figure 7 Dentalina pseudonana ten Dam.

Sample 416A-54, CC. Scale $50 \mu \mathrm{m}$.

Figure 8 Dentalina soluta Reuss.

Sample 416A-17-3, 12-15 cm. Scale $100 \mu \mathrm{m}$.

Figure 9 Dentalina torta Terquem.

Sample 416A-55-2, $42-44 \mathrm{~cm}$. Scale $30 \mu \mathrm{m}$.

Figures 10, 11 Dentalina varians Terquem. Scale $100 \mu \mathrm{m}$.

10. Sample 416A-32-4, 104-106 cm.

11. Sample 416A-12-2, 144-146 cm.

Figures 12,13 Frondicularia didyma Berthelin.

Sample 416A-7-3, 33-35 cm. Scale $100 \mu \mathrm{m}$.

Figure $14 \quad$ Frondicularia hastata hastata Roemer.

Juvenile specimen. Sample 416A-23-5, 9-11 cm. Scale $100 \mu \mathrm{m}$.

Figures 15, 16 Frondicularia intermittens Reuss. Scale $100 \mu \mathrm{m}$.

15. Sample 416A-23-5, 59-60 cm.

16. Broken specimen showing surface ornamentation. Sample 416A-24-3, 36-38 cm.

Figures 17, 18 Frondicularia inversa Reuss.

17. Adult specimen. Sample 416A-26-1, 36-38 cm. Scale $300 \mu \mathrm{m}$.

18. Juvenile specimen. Sample 416A-28, CC. Scale $60 \mu \mathrm{m}$.

Figure $19 \quad$ Frondicularia joidesi Maync.

Sample 416A-14-2, 116-118 cm. Scale $150 \mu \mathrm{m}$.

Figure $20 \quad$ Frondicularia rehburgensis Bartenstein and Brand.

Sample 416A-32-4, 104-106 cm. Scale $100 \mu \mathrm{m}$.

Figure $21 \quad$ Lagena globosa (Montagu).

Sample 416A-14-1, $119-120 \mathrm{~cm}$. Scale $30 \mu \mathrm{m}$.

Figure 22 Frondicularia simplicissima ten Dam.

Sample 416A-11-5, 45-46 cm. Scale $50 \mu \mathrm{m}$.

Figure 23 Frondicularia sp.

Sample 416A-25-4, 125-127 cm. Scale $100 \mu \mathrm{m}$.

Figure 24 Kyphopyxa sp.

Sample 416A-29-6, 4-5 cm. Scale $60 \mu \mathrm{m}$.

Figures 25, 26 Lagena hauteriviana cylindracea Bartenstein and Brand.

Sample 416A-9-3, 100-102 cm. Scale $100 \mu \mathrm{m}$. 
PLATE 7

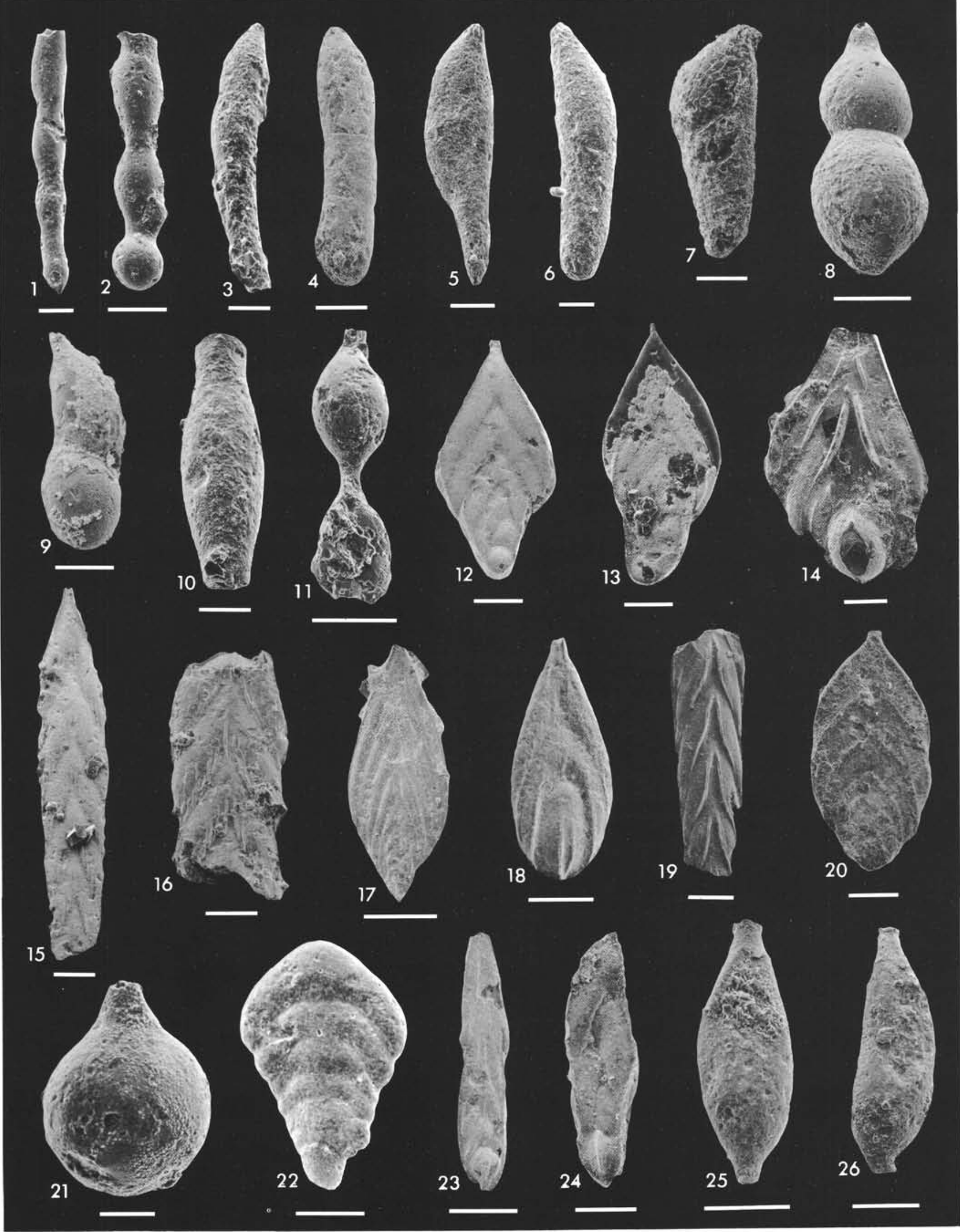




\section{PLATE 8}

Figures 1, 2 Lagena hauteriviana hauteriviana Bartenstein and Brand.

1. Sample 416A-12-5, 30-32 cm. Scale $50 \mu \mathrm{m}$.

2. Sample 416A-29-5, 3-5 cm. Scale $30 \mu \mathrm{m}$.

Figures 3, $4 \quad$ Lagena laevis (Montagu).

Scale $30 \mu \mathrm{m}$.

3. Sample 416A-30-3, 143-144 cm.

4. Rare specimen with initial spine. Sample 416A-26-4, 11-13 cm.

Figure $5 \quad$ Lagena sp. cf. L. meridionalis Wiesner.

Sample 416A-15-1, 38-39 cm. Scale $50 \mu \mathrm{m}$.

Figure $6 \quad$ Lagena ovata (Terquem).

Sample 416A-54, CC. Scale $30 \mu \mathrm{m}$.

Figure $7 \quad$ Lagena oxystoma Reuss.

Sample 416A-15-1, 38-39 cm. Scale $60 \mu \mathrm{m}$.

Figures 8-10 Lagena sulcata (Walker and Jacob).

Scale $100 \mu \mathrm{m}$.

8. Sample 416A-31-3, 7-9 cm.

9. Sample $416 \mathrm{~A}-27-4,135-137 \mathrm{~cm}$.

10. Sample 416A-23-5, $59-60 \mathrm{~cm}$.

Figures 11-14 Lagena sztejnae Dieni and Massari.

11. Sample 416A-28-2, 0-2 cm. Scale $30 \mu \mathrm{m}$.

12. Sample 416A-43, CC. Scale $30 \mu \mathrm{m}$.

13. Sample 416A-20-2, $11-12 \mathrm{~cm}$. Scale $50 \mu \mathrm{m}$.

14. Rare double specimen. Sample $416 \mathrm{~A}-23-5,59-60 \mathrm{~cm}$. Scale $50 \mu \mathrm{m}$.

Figures 15-18 Lenticulina busnardoi Moullade.

Scale $100 \mu \mathrm{m}$.

15. Side view. Sample 416A-28-4, 11-13 cm.

16. Side view. Sample 416A-38, CC.

17. Side view. Sample 416A-14-2, 116-118 cm.

18. Face view of same specimen.

Figures 19, 20 Lenticulina eichenbergi Bartenstein and Brand.

Sample 416A-7-3, 33-35 cm. Scale $100 \mu \mathrm{m}$.

19. Side view of corroded juvenile specimen.

20. Face view of same specimen.

Figure $21 \quad$ Lenticulina guttata (ten Dam).

Side view. Sample 416A-9-3, 98-99 cm. Scale $100 \mu \mathrm{m}$. 
PLATE 8

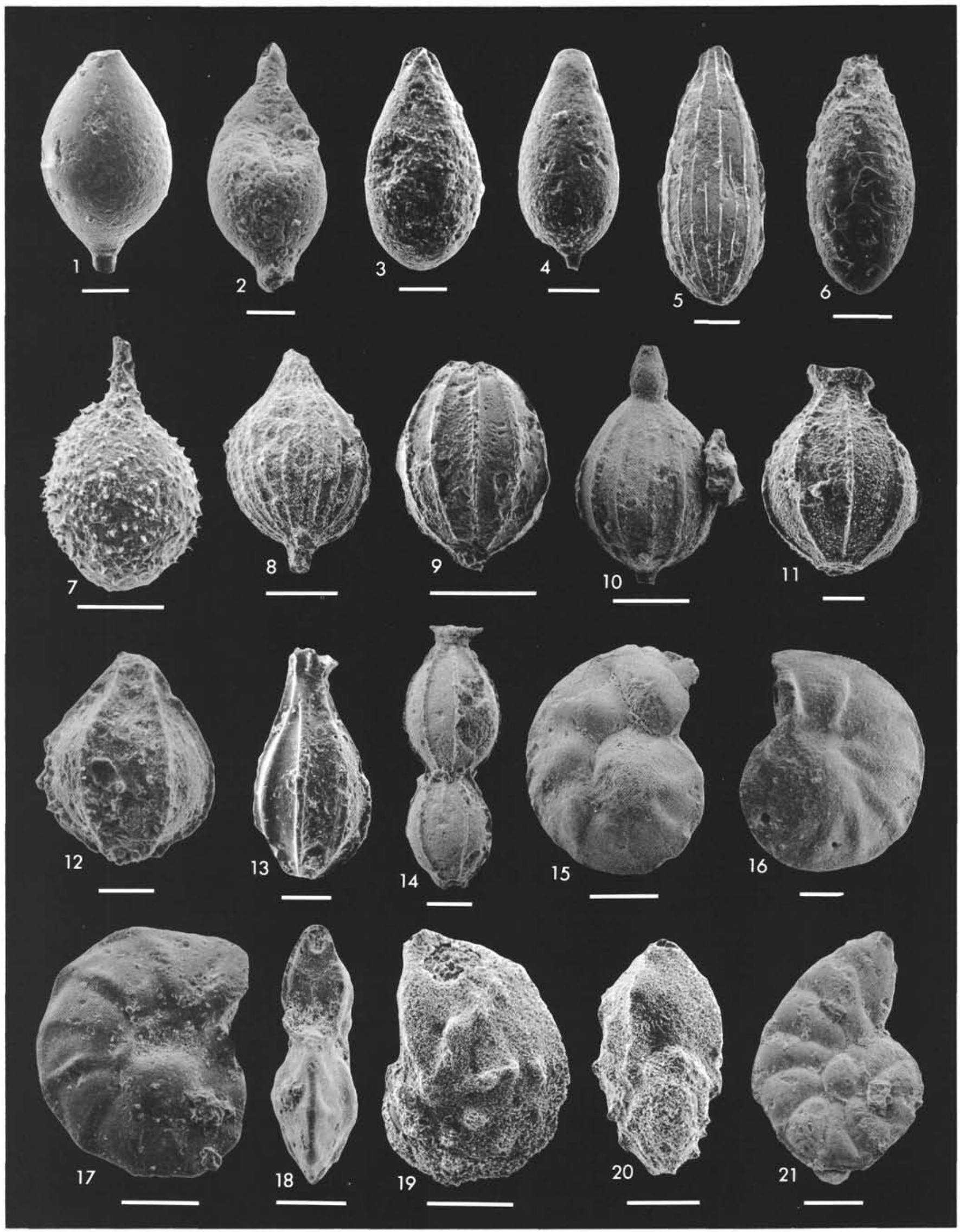




\section{PLATE 9}

Figures 1, 2 Lenticulina guttata (ten Dam).

Sample 416A-15-1, 38-39 cm. Scale $100 \mu \mathrm{m}$.

1. Side view.

2. Side view of less-compressed specimen.

Figures 3, $4 \quad$ Lenticulina muensteri (Roemer).

Sample 416A-35-3, 0-1 cm. Scale $200 \mu \mathrm{m}$.

3. Side view.

4. Face view of same specimen.

Figures 5-8 Lenticulina nodosa (Reuss).

Scale $100 \mu \mathrm{m}$.

5. Side view. Sample 416A-10-1, 141-143 cm.

6. Face view of same specimen.

7. Side view. Sample 416A-14-2, 116-118 cm.

8. Side view. Sample $416 \mathrm{~A}-14-2,116-118 \mathrm{~cm}$.

Figures 9, 10 Lenticulina ouachensis multicella Bartenstein, Bettenstaedt, and Bolli.

Sample 416A-9-3, 99-100 cm.

9. Side view. Scale $300 \mu \mathrm{m}$.

10. Side view. Scale $200 \mu \mathrm{m}$.

Figures 11-16 Lenticulina ouachensis ouachensis (Sigal). Sample 416A-9-3, 99-100 cm. Scale $100 \mu \mathrm{m}$.

11. Side view.

12. Face view of same specimen.

13. Side view.

14. Face view of same specimen.

15. Side view.

16. Face view of same specimen. 


\section{PLATE 9}
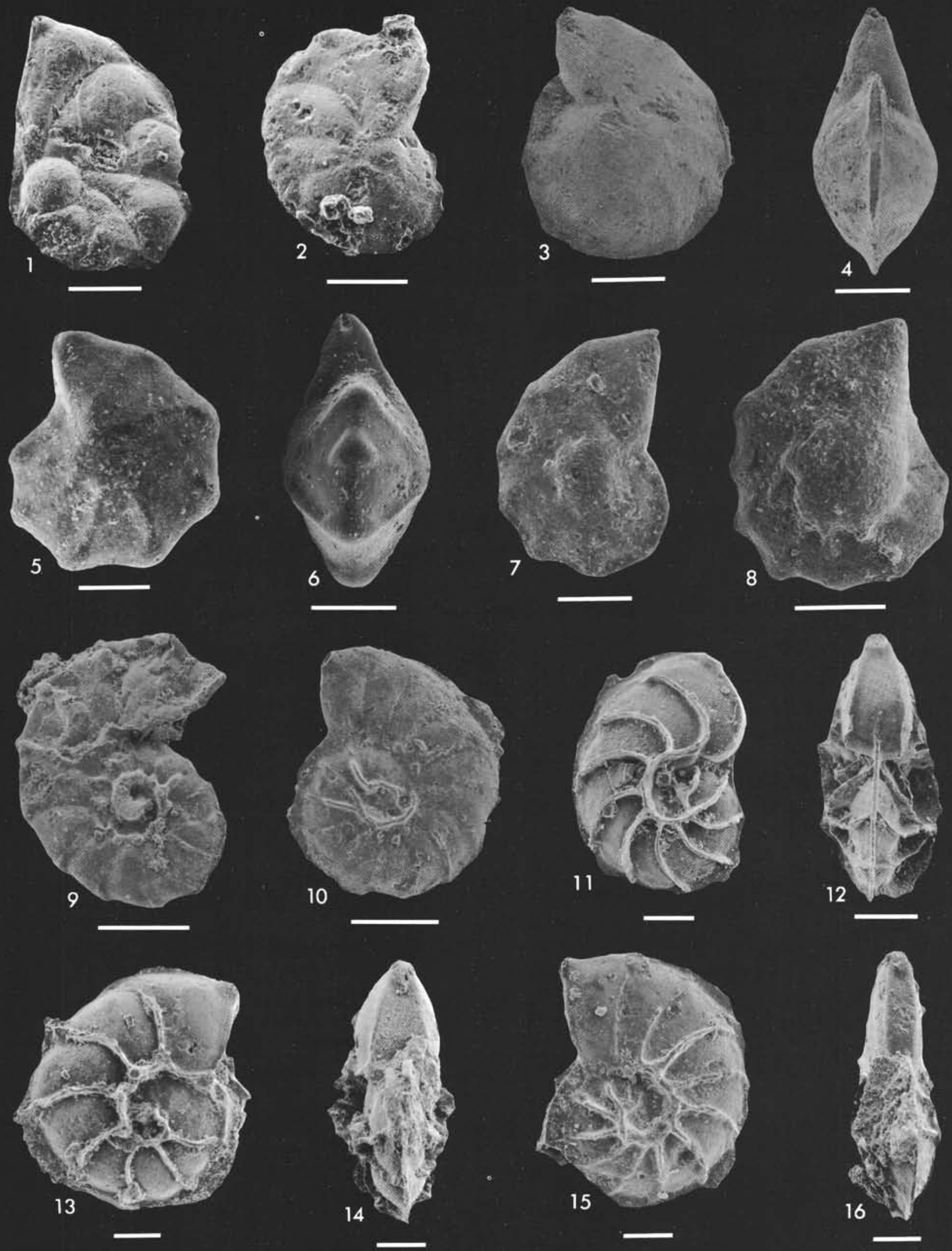


\section{PLATE 10}

Figures 1-4 Lenticulina ouachensis ouachensis (Sigal). Sample 416A-12-5, 30-32 cm.

1. Side view. Scale $50 \mu \mathrm{m}$.

2. Face view of same specimen. Scale $50 \mu \mathrm{m}$.

3. Side view of aberrant specimen. Scale $100 \mu \mathrm{m}$.

4. Face view of same specimen. Scale $100 \mu \mathrm{m}$.

Figures 5-7, 10 Lenticulina praegaultina Bartenstein, Bettenstaedt, and Bolli.

Scale $100 \mu \mathrm{m}$.

5. Side view. Sample 416 A-22-4, 119-121 cm.

10. Face view of same specimen.

6. Side view. Sample 416A-22-3, 108-109 cm.

7. Face view of same specimen.

Figures 8, 9, Lenticulina subalata (Reuss).

$11-16$

8. Side view. Sample $416 \mathrm{~A}-40-4,83-85 \mathrm{~cm}$. Scale $100 \mu \mathrm{m}$.

9. Side view. Sample $416 \mathrm{~A}-23-5,59-60 \mathrm{~cm}$. Scale $100 \mu \mathrm{m}$.

11. Side view aberrant specimen. Sample 416A22-3, 108-109 cm. Scale $100 \mu \mathrm{m}$.

12. Face view of same specimen. Scale $100 \mu \mathrm{m}$.

13. Side view of aberrant specimen. Sample 416A$22-3,108-109 \mathrm{~cm}$. Scale $200 \mu \mathrm{m}$.

14. Face view of same specimen. Scale $200 \mu \mathrm{m}$.

15. Side view of aberrant specimen. Specimen $416 \mathrm{~A}-22-3,108-109 \mathrm{~cm}$. Scale $200 \mu \mathrm{m}$.

16. Face view of same specimen. Scale $200 \mu \mathrm{m}$.

Figures 17, 18 Lenticulina subangulata (Reuss).

17. Side view. Sample 416A-22-3, 108-109 cm. Scale $200 \mu \mathrm{m}$.

18. Side view of earliest specimen at Site 416 . Sample 416A-43-2, 30-32 cm. Scale $60 \mu \mathrm{m}$. 


\section{PLATE 10}

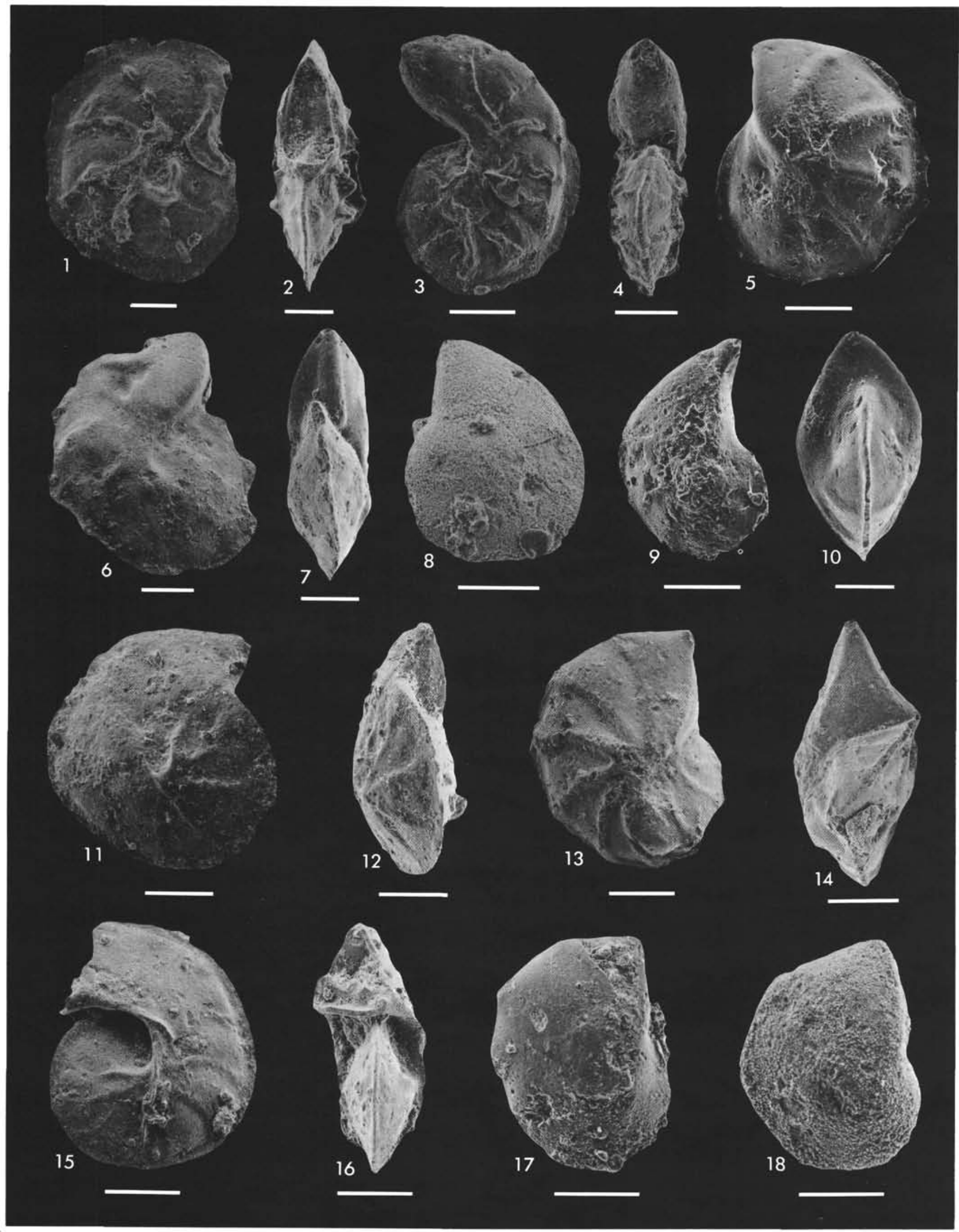




\section{PLATE 11}

Figures 1-5 Lenticulina turgidula (Reuss).

1. Side view. Sample 416A-15-1, 38-39 cm. Scale $100 \mu \mathrm{m}$.

2. Face view of same specimen. Scale $100 \mu \mathrm{m}$.

3. Side view. Sample 416A-12-5, 30-32 cm. Scale $100 \mu \mathrm{m}$.

4. Face view of same specimen. Scale $100 \mu \mathrm{m}$.

5. Side view of aberrant specimen. Sample 416A$14-2,114-116 \mathrm{~cm}$. Scale $60 \mu \mathrm{m}$.

Figures 6-8 Lenticulina $\mathrm{sp}$. A.

Sample 416A-25-3, 51-52 cm. Scale $100 \mu \mathrm{m}$.

6. Side view.

7. Face view of same specimen.

8 . Side view.

Figure $9 \quad$ Lenticulina sp. B.

Sample 416A-12-5, 30-32 cm. Scale $100 \mu \mathrm{m}$.

Figures 10, 11 Lenticulina sp. C.

Sample 416A-9-3, 99-100 cm. Scale $100 \mu \mathrm{m}$.

10. Side view.

11. Face view of same specimen.

Figures 12, 13 Marginulinopsis bettenstaedti (Bartenstein and Brand).

Sample 416A-26-1, 36-38 cm. Scale $100 \mu \mathrm{m}$.

12. Side view.

13. Face view of same specimen.

Figures 14, 15 Marginulinopsis cephalotes (Reuss).

Sample 416A-12-5, 30-32 cm. Scale $100 \mu \mathrm{m}$.

14. Side view.

15. Side view.

Figures 16-18 Marginulinopsis collignoni (Espitalié and Sigal).

16. Side view. Sample 416A-11-6, 61-63 cm.

Scale $30 \mu \mathrm{m}$.

17. Side view. Sample 416A-12-5, 30-32 cm. Scale $50 \mu \mathrm{m}$.

18. Face view of same specimen. Scale $50 \mu \mathrm{m}$. 

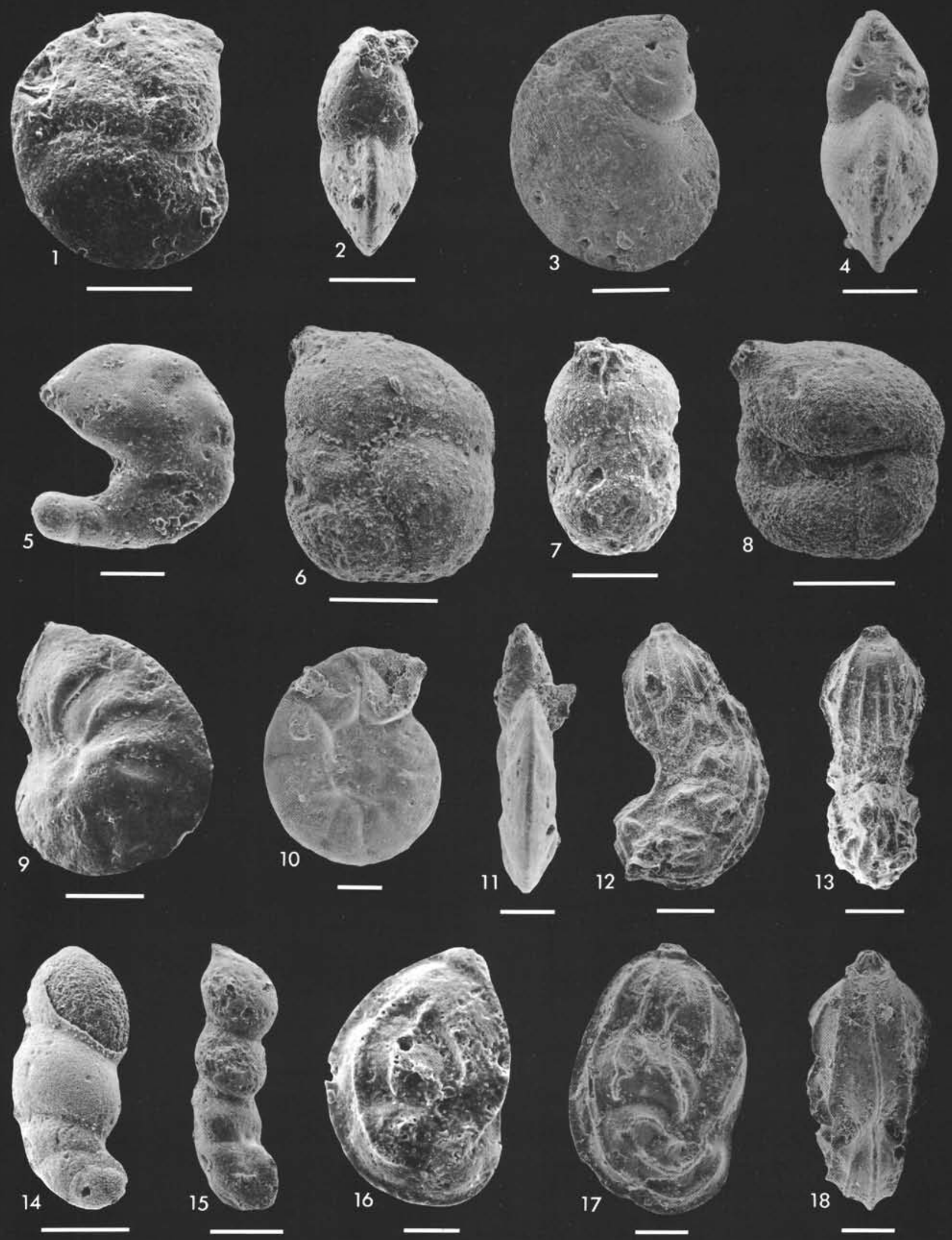


\section{PLATE 12}

Figure $1 \quad$ Marginulinopsis parkeri (Reuss).

Side view. Sample $416 \mathrm{~A}-26-1,36-38 \mathrm{~cm}$. Scale $100 \mu \mathrm{m}$.

Figures 2, 3 Pseudonodosaria humilis (Roemer).

Scale $100 \mu \mathrm{m}$.

2. Sample 416A-31-3, 7-9 cm.

3. Sample 416A-35-3, 0-1 cm.

Figure 4 Saracenaria compacta Espitalié and Sigal.

Sample 416A-34, CC. Scale $100 \mu \mathrm{m}$.

Figures 5-7 Saracenaria cushmani Tappan.

Scale $100 \mu \mathrm{m}$.

5. Side view. Sample $416 \mathrm{~A}-28-2,0-2 \mathrm{~cm}$.

6. Side view. Sample $416 \mathrm{~A}-26-1,36-38 \mathrm{~cm}$.

7. Face view of same specimen.

Figures 8, 9 Saracenaria frankei ten Dam.

Scale $100 \mu \mathrm{m}$.

8. Oblique side view. Sample 416A-36-2, 96-97 $\mathrm{cm}$.

9. Oblique side view. Sample 416A-25-4, 125$127 \mathrm{~cm}$.

Figures 10-14 Saracenaria saxonica saxonica (Bartenstein and Brand).

Scale $100 \mu \mathrm{m}$.

10. Side view. Sample $416 \mathrm{~A}-40-4,83-85 \mathrm{~cm}$.

11. Side view. Sample 416A-22-4, 119-121 cm.

12. Face view of same specimen.

13. Side view. Sample 416A-26-1, 36-38 cm.

14. Face view of same specimen.

Figures 15-17 Vaginulina recta Reuss.

15. Side view. Sample 416A-14-2, 114-116 cm. Scale $100 \mu \mathrm{m}$.

16. Side view. Sample 416A-9-3, 99-100 cm. Scale $300 \mu \mathrm{m}$.

17. Side view. Sample 416A-9-3, 99-100 cm. Scale $300 \mu \mathrm{m}$.

Figure $18 \quad$ Vaginulina angustissima Reuss.

Side view. Sample 416A-9-3, 99-100 cm. Scale $150 \mu \mathrm{m}$.

Figures 19-20 Vaginulina debilis (Berthelin).

Scale $100 \mu \mathrm{m}$.

19. Sample 416A-28-1, 17-19 cm.

20. Sample 416A-26-1, 36-38 cm.

Figures 21, 22 Vaginulinopsis excentrica (Cornuel). Scale $100 \mu \mathrm{m}$.

21. Side view. Sample 416A-12-5, 30-32 cm.

22. Face view of same specimen. 


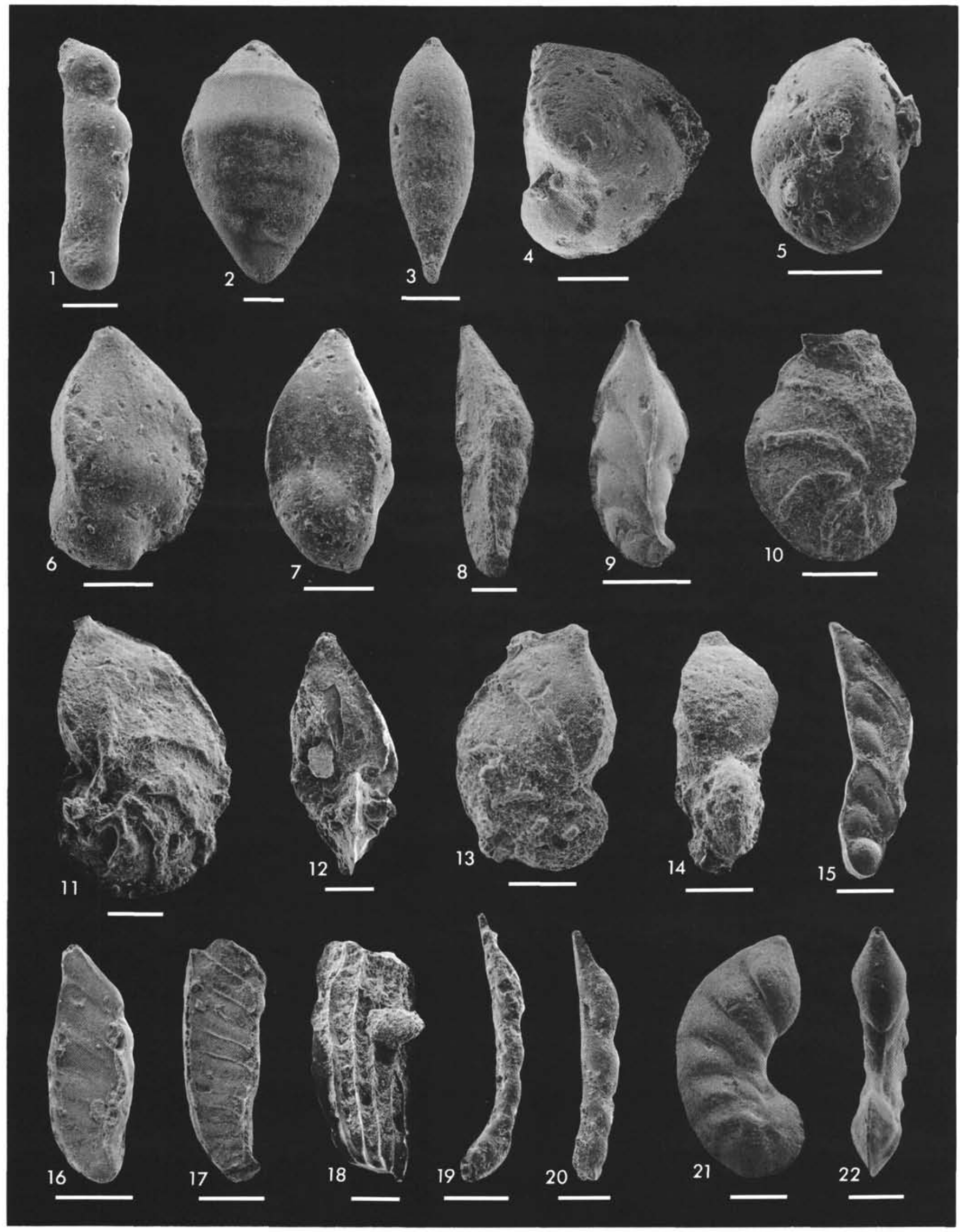




\section{PLATE 13}

Figure $1 \quad$ Vaginulinopsis excentrica (Cornuel).

Side view. Sample 416A-9-3, 99-100 cm. Scale $100 \mu \mathrm{m}$.

Figure 2 Vaginulinopsis matutina (d'Orbigny).

Side view. Sample 416A-43-2, 30-32 cm. Scale $100 \mu \mathrm{m}$.

Figure $3 \quad$ Vaginulinopsis pseudodebilis (Dieni and Massari).

Side view of broken specimen. Sample 416A-14-2, 114-116 cm. Scale $100 \mu \mathrm{m}$.

Figure $4 \quad$ Vaginulinopsis reticulosa ten Dam.

Side view of specimen partially obscured by debris. Sample 416A-7-3, 33-35 cm. Scale $200 \mu \mathrm{m}$.

Figure $5 \quad$ Vaginulinopsis schloenbachi (Reuss).

Side view. Sample 416A-28-4, 11-13 cm. Scale $100 \mu \mathrm{m}$.

Figure $6 \quad$ Vaginulinopsis sp. A.

Side view. Sample 416A-46-3, 46-48 cm. Scale $100 \mu \mathrm{m}$.

Figures 7, $8 \quad$ Vaginulinopsis sp. B.

7. Side view. Sample 416A-44, CC. Scale $60 \mu \mathrm{m}$.

8. Side view. Sample $416 \mathrm{~A}-45-1,36-38 \mathrm{~cm}$. Scale $100 \mu \mathrm{m}$.

Figure $9 \quad$ Vaginulinopsis sp. C.

Side view. Sample 416A-43-2, 30-32 cm. Scale $100 \mu \mathrm{m}$.

Figure $10 \quad$ Vaginulinopsis sp. D.

Side view. Sample 416A-19-2, 111-113 cm. Scale $60 \mu \mathrm{m}$.

Figures 11, 12 Lingulina loryi (Berthelin).

Scale $100 \mu \mathrm{m}$.

11. Side view. Sample 416A-31-3, 7-9 cm.

12. Side view. Sample 416A-25-4, $125-127 \mathrm{~cm}$.

Figure $13 \quad$ Lingulina nodosaria Reuss.

Side view. Sample 416A-28-6, 149-151 cm. Scale $100 \mu \mathrm{m}$.

Figure $14 \quad$ Lingulina pupa (Terquem).

Side view. Sample 416A-35-2, 104-106 cm. Scale $30 \mu \mathrm{m}$.

Figure $15 \quad$ Lingulina semiornata Reuss.

Side view. Sample 416A-30-3, 143-144 cm. Scale $30 \mu \mathrm{m}$.

Figure 16 Lingulina sp. Side view. Sample 416A-38, CC. Scale $30 \mu \mathrm{m}$.

Figure $17 \quad$ Eoguttulina oolithica (Terquem).

Sample 416A-55-2, 63-65 cm. Scale $30 \mu \mathrm{m}$.

Figures 18, 19 Falsoguttulina wolburgi Bartenstein and Brand.

Sample 416A-43-2, 30-33 cm. Scale $30 \mu \mathrm{m}$.

18. Side view.

19. Peripheral view of same specimen.

Figures 20, 21 Globulina exserta (Berthelin).

Sample 416A-29-5, 3-5 cm. Scale $30 \mu \mathrm{m}$.

Figure 22 Globulina prisca Reuss.

Sample 416A-17-3, 12-15 cm. Scale $100 \mu \mathrm{m}$. 

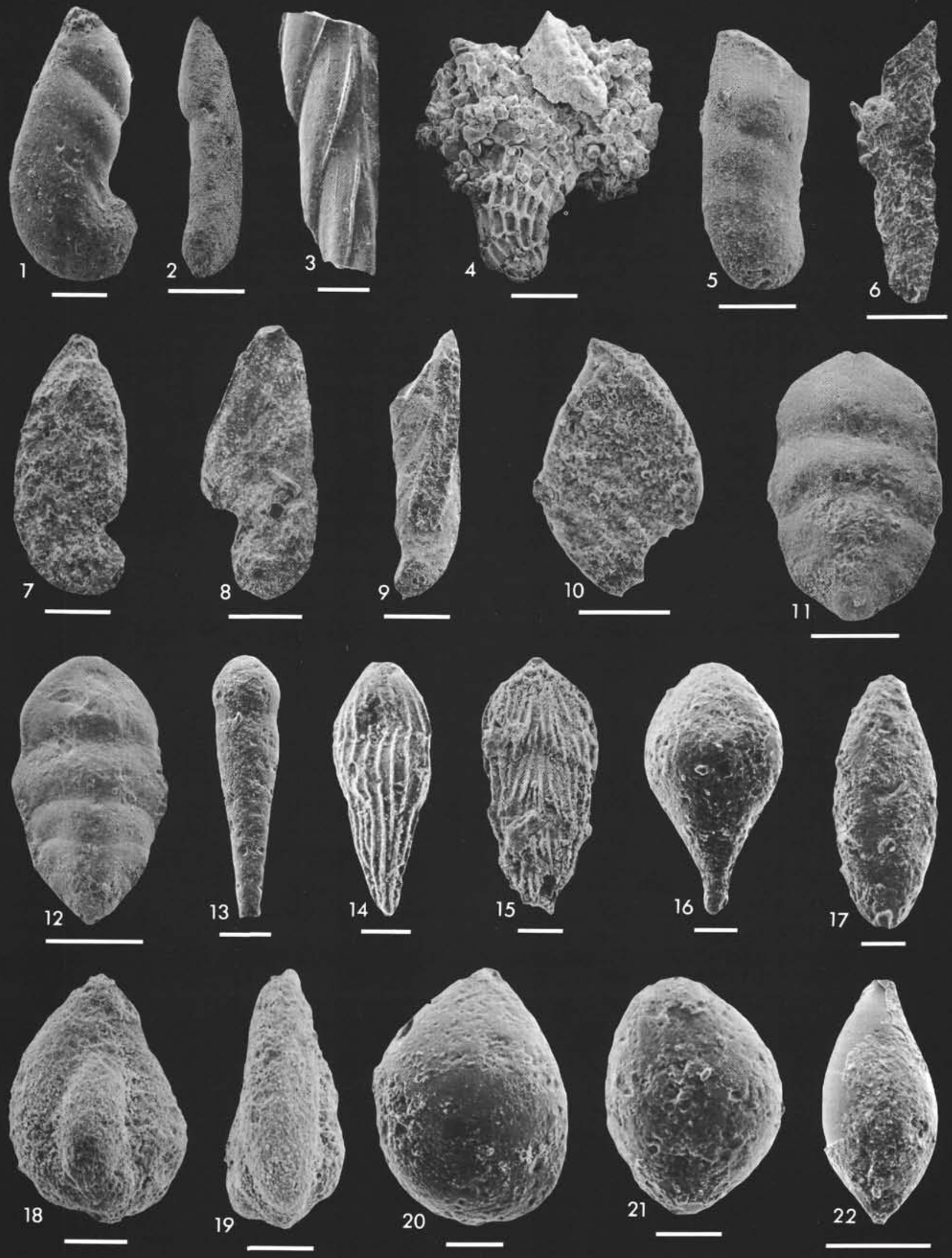


\section{PLATE 14}

Figure $1 \quad$ Globulina prisca Reuss. Sample 416A-17-3, 12-15 cm. Scale $100 \mu \mathrm{m}$.

Figure 2 Pyrulina cylindroides (Roemer). Sample 416A-14-2, 114-116 cm. Scale $50 \mu \mathrm{m}$.

Figures 3, $4 \quad$ Ramulina aculeata Wright.

Scale $100 \mu \mathrm{m}$.

3. Globular chamber. Sample 416A-15-1, 38-39 $\mathrm{cm}$.

4. Fragment of interconnecting tube. Sample $416 \mathrm{~A}-19-2,111-113 \mathrm{~cm}$.

Figure 5 Ramulina globotubulosa Cushman. Sample 416A-27-4, 135-137 cm. Scale $100 \mu \mathrm{m}$.

Figure $6 \quad$ Ramulina spandeli Paalzow.

Sample 416A-55-2, 7-9 cm. Scale $100 \mu \mathrm{m}$.

Figures 7, 8 Tristix acutangula (Reuss).

Scale $100 \mu \mathrm{m}$.

7. Sample 416A-7-3, 125-127 cm.

8. Sample 416A-12-5, 30-32 cm.

Figure $9 \quad$ Tristix excavata (Reuss).

Sample 416A-11-5, 45-46 cm. Scale $30 \mu \mathrm{m}$.

Figures 10-18 Tristix lanceola Sliter, n. sp.

10. Side view of holotype (USNM 252178). Sample $416 \mathrm{~A}-17-3,12-15 \mathrm{~cm}$. Scale $60 \mu \mathrm{m}$.

11. Apertural view of holotype. Scale $30 \mu \mathrm{m}$.

12. Enlargement of apertural area of holotype. Scale $10 \mu \mathrm{m}$.

13. Side view of paratype (USNM 252179). Sample $416 \mathrm{~A}-12-5,30-35 \mathrm{~cm}$. Scale $60 \mu \mathrm{m}$.

18. Apertural view of same specimen. Scale 30 $\mu \mathrm{m}$.

14. Side view of paratype (USNM 252180). Sample $416 \mathrm{~A}-17-3,12-15 \mathrm{~cm}$. Scale $60 \mu \mathrm{m}$.

15. Apertural view of same specimen. Scale $30 \mu \mathrm{m}$.

16. Apertural view of paratype (USNM 252498). Sample 416A-30-3, 143-144 cm. Scale $30 \mu \mathrm{m}$.

17. Side view of same specimen. Scale $60 \mu \mathrm{m}$. 

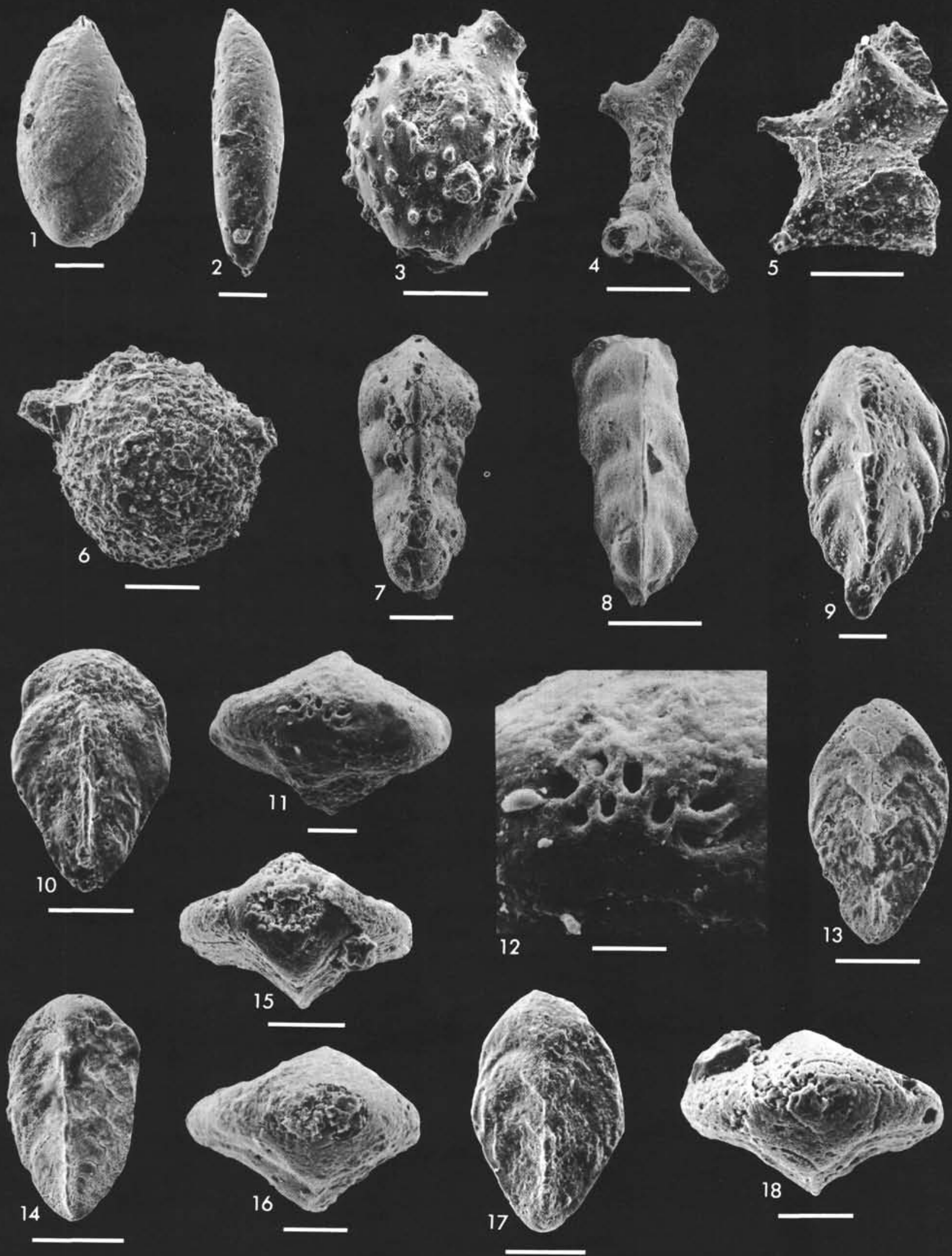


\section{PLATE 15}

Figures 1, 2 Spirillina elongata Bielecka and Pozaryski.

Scale $30 \mu \mathrm{m}$.

1. Sample 416A-55-2, 7-9 cm.

2. Sample 416A-54, CC.

Figures 3, 4 Spirillina minima Schacko.

3. Sample 416A-35-3, 0-1 cm. Scale $60 \mu \mathrm{m}$.

4. Sample 416A-26-1, 36-38 cm. Scale $100 \mu \mathrm{m}$.

Figures 5, 6 Spirillina tenuissima Gümbel.

Sample 416A-29-6, 4-5 cm. Scale $100 \mu \mathrm{m}$.

Figures 7-10 Turrispirillina conoidea (Paalzow).

7. Spiral view. Sample 416A-30-3, 143-144 cm. Scale $30 \mu \mathrm{m}$.

8. Umbilical view of same specimen. Scale 30 $\mu \mathrm{m}$.

9. Umbilical view. Sample 416A-38, CC. Scale $50 \mu \mathrm{m}$.

10. Peripheral view of same specimen. Scale 30 $\mu \mathrm{m}$.

Figures 11-15 Patellina feifeli (Paalzow).

11. Spiral view. Sample 416A-54, CC. Scale 60 $\mu \mathrm{m}$.

12. Peripheral view of same specimen. Scale 30 $\mu \mathrm{m}$.

13-15. Spiral, peripheral, and umbilical views of same specimen. Sample 416A-40-4, 83-85 $\mathrm{cm}$. Scale $100 \mu \mathrm{m}$. 


\section{PLATE 15}
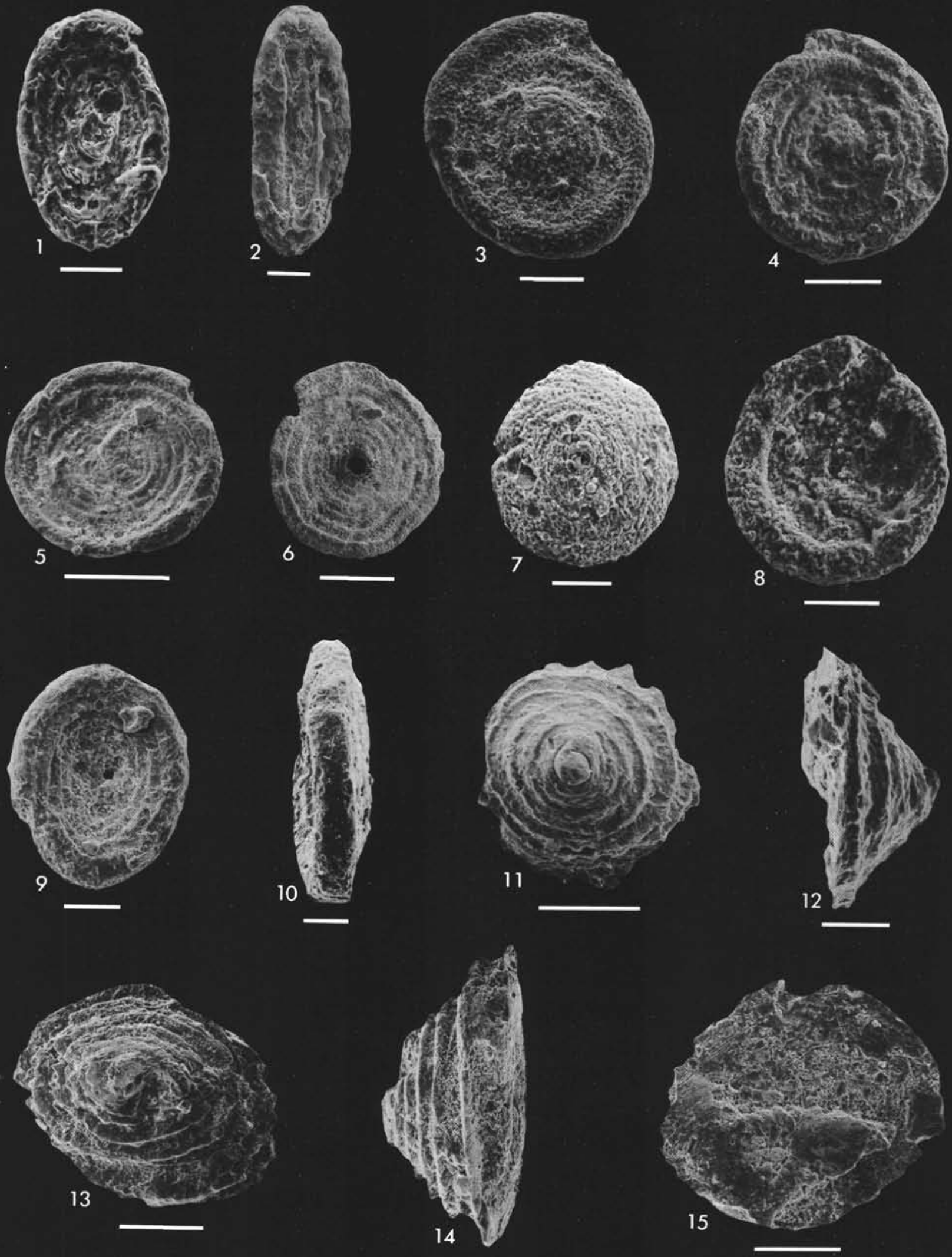


\section{PLATE 16}

Figures 1-4 Patellina subcretacea Cushman and Alexander. Scale $60 \mu \mathrm{m}$.

1-3. Spiral, peripheral and umbilical views of same specimen. Sample 416A-27-4, 135$137 \mathrm{~cm}$.

4. Spiral view. Sample 416A-12-5, 30-32 cm.

Figures 5-7 Patellina turriculata Dieni and Massari.

Spiral, peripheral, and umbilical views of same specimen. Sample 416A-17-3, 12-15 cm.

5. Scale $100 \mu \mathrm{m}$.

6,7 . Scale $60 \mu \mathrm{m}$.

Figure $8 \quad$ Guembelitria cenomana (Keller).

Sample 415A-15, CC. Scale $30 \mu \mathrm{m}$.

Figures 9-11 Gubkinella graysonensis (Tappan).

Scale $30 \mu \mathrm{m}$.

9. Apertural view. Sample 415A-8, CC.

10. Spiral view. Sample 415A-8-2, 105-107 cm.

11. Side view. Sample 415A-8, CC.

Figures 12-14 Heterohelix moremani (Cushman).

12. Sample 415A-10-2, $15-18 \mathrm{~cm}$. Scale $50 \mu \mathrm{m}$.

13. Sample $415 \mathrm{~A}-9-2,13-15 \mathrm{~cm}$. Scale $30 \mu \mathrm{m}$.

14. Sample $415 \mathrm{~A}-8-2,105-107 \mathrm{~cm}$. Scale $30 \mu \mathrm{m}$.

Figures 15, 16 Globigerinelloides bentonensis (Morrow).

15. Peripheral view. Sample 415A-12-2, 104-105 $\mathrm{cm}$. Scale $100 \mu \mathrm{m}$.

16. Side view. Sample 415A-13-1, 64-66 cm. Scale $60 \mu \mathrm{m}$. 

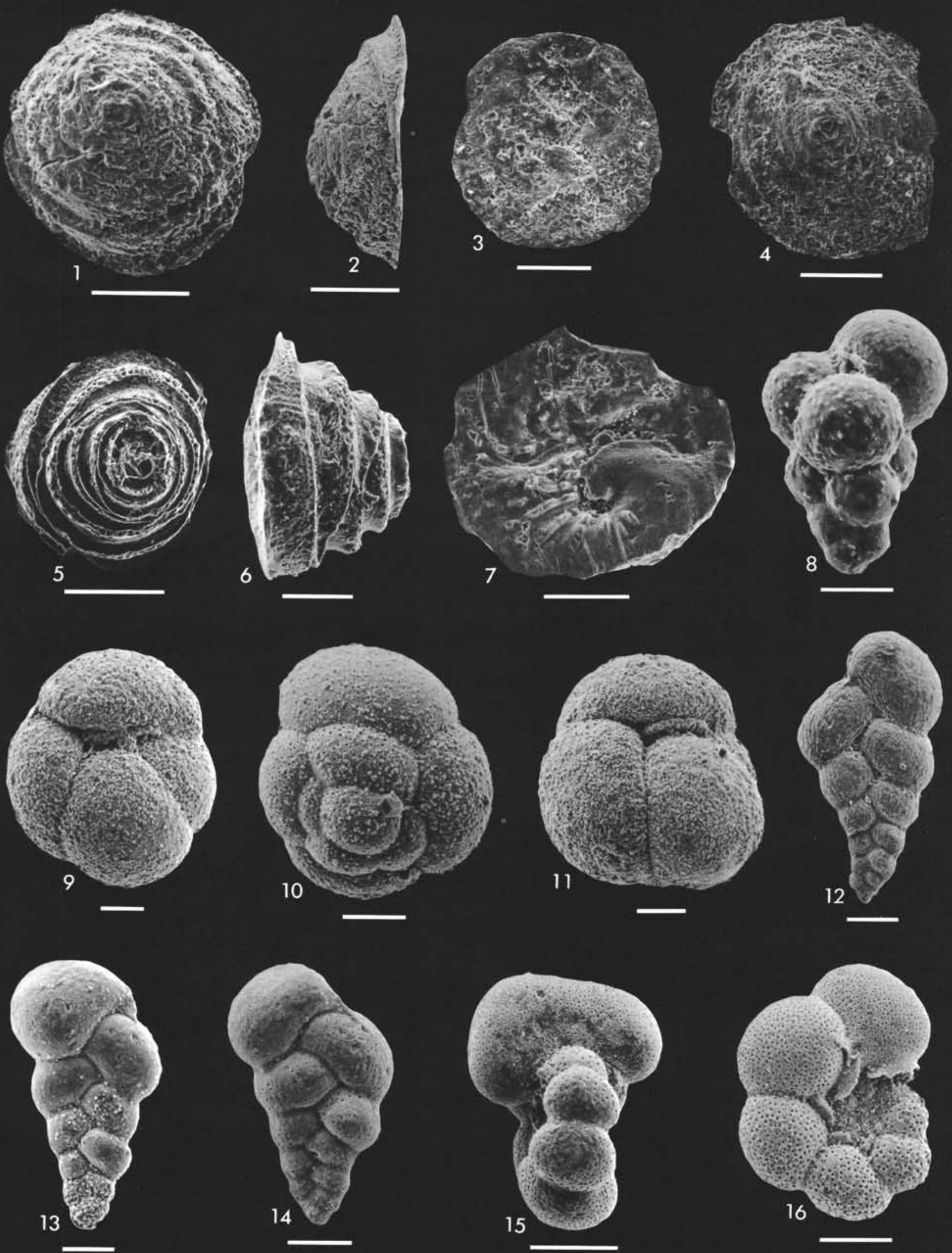


\section{PLATE 17}

Figure $1 \quad$ Globigerinelloides bentonensis (Morrow).

Peripheral view. Sample 415A-13-1, 64-66 cm. Scale $100 \mu \mathrm{m}$.

Figures 2, 3 Globigerinelloides caseyi (Bolli, Loeblich, and Tappan).

Scale $30 \mu \mathrm{m}$.

2. Side view. Sample $415 \mathrm{~A}-13-1,64-66 \mathrm{~cm}$.

3. Peripheral view. Sample 415A-14-1, 131-133 $\mathrm{cm}$.

Figures 4, 8 Schackoina cenomana (Schacko).

Scale $30 \mu \mathrm{m}$.

4. Side view. Sample $415 \mathrm{~A}-11, \mathrm{CC}, 13-15 \mathrm{~cm}$.

8. Peripheral view. Sample 415A-13-1, 64-66 $\mathrm{cm}$.

Figures 5-7, 9 Schackoina multispinata (Cushman and Wickenden)

5. Side view. Sample $415 \mathrm{~A}-11, \mathrm{CC}, 13-15 \mathrm{~cm}$. Scale $30 \mu \mathrm{m}$.

6. Peripheral view. Sample 415 A-12-1, 18-20 $\mathrm{cm}$. Scale $30 \mu \mathrm{m}$.

7. Peripheral view. Sample 415A-12, CC. Scale $100 \mu \mathrm{m}$.

9. Side view. Sample 415A-12, CC. Scale 100 $\mu \mathrm{m}$.

Figures 10-12 Hedbergella delrioensis (Carsey).

Sample 415A-9-1, 88-90 cm. Scale $60 \mu \mathrm{m}$.

10. Umbilical view.

11. Peripheral view.

12. Spiral view.

Figures 13-16 Hedbergella sp. cf. H. delrioensis (Carsey).

13. Spiral view. Sample 415A-14-1, 131-133 cm. Scale $60 \mu \mathrm{m}$.

14. Peripheral view. Sample 415A-14-1, 131-133 $\mathrm{cm}$. Scale $60 \mu \mathrm{m}$.

15. Umbilical view. Sample 415A-13-1, 64-66 $\mathrm{cm}$. Scale $100 \mu \mathrm{m}$.

16. Spiral view. Sample 415A-11, CC, $13-15 \mathrm{~cm}$. Scale $60 \mu \mathrm{m}$. 

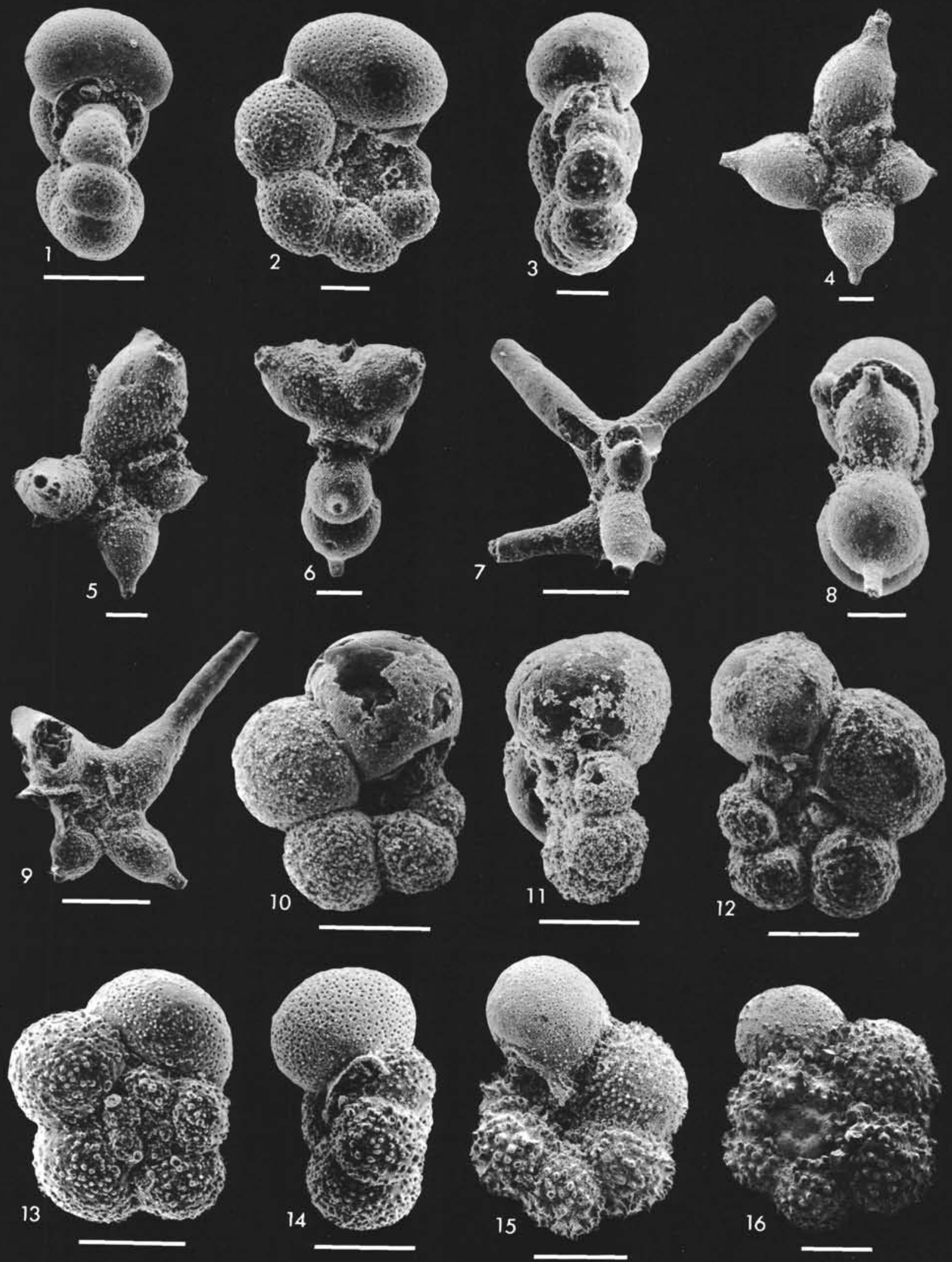

16 


\section{PLATE 18}

Figures 1, 2 Hedbergella infracretacea (Glaessner). Sample 415A-14-1, 131-133 cm. Scale $30 \mu \mathrm{m}$.

Figures 3-6 Hedbergella planispira (Tappan).

Scale $30 \mu \mathrm{m}$.

3. Spiral view. Sample 415A-9-1, 88-90 cm.

4. Peripheral view of same specimen.

5. Spiral view. Sample 415 A-9-1, $88-90 \mathrm{~cm}$.

6. Umbilical view. Sample 415A-8, CC.

Figures 7-10 Hedbergella simplicissima (Magné and Sigal). Scale $30 \mu \mathrm{m}$.

7. Spiral view. Sample $415 \mathrm{~A}-15$, CC.

8. Peripheral view. Sample 415A-15, CC.

9. Umbilical view. Sample 415A-15, CC.

10. Umbilical view. Sample 415A-11, CC, 13-15 $\mathrm{cm}$.

Figures 11-14 Hedbergella sp.

Sample 415A-11, CC, $13-15 \mathrm{~cm}$. Scale $30 \mu \mathrm{m}$.

11. Spiral view.

12. Peripheral view.

13. Umbilical view of specimen in Figure 11.

14. Oblique peripheral view.

Figures 15, 16 Clavihedbergella simplex (Morrow).

Scale $30 \mu \mathrm{m}$.

15. Umbilical view. Sample 415A-9-5, 10-12 cm.

16. Spiral view. Sample 415A-8, CC. 


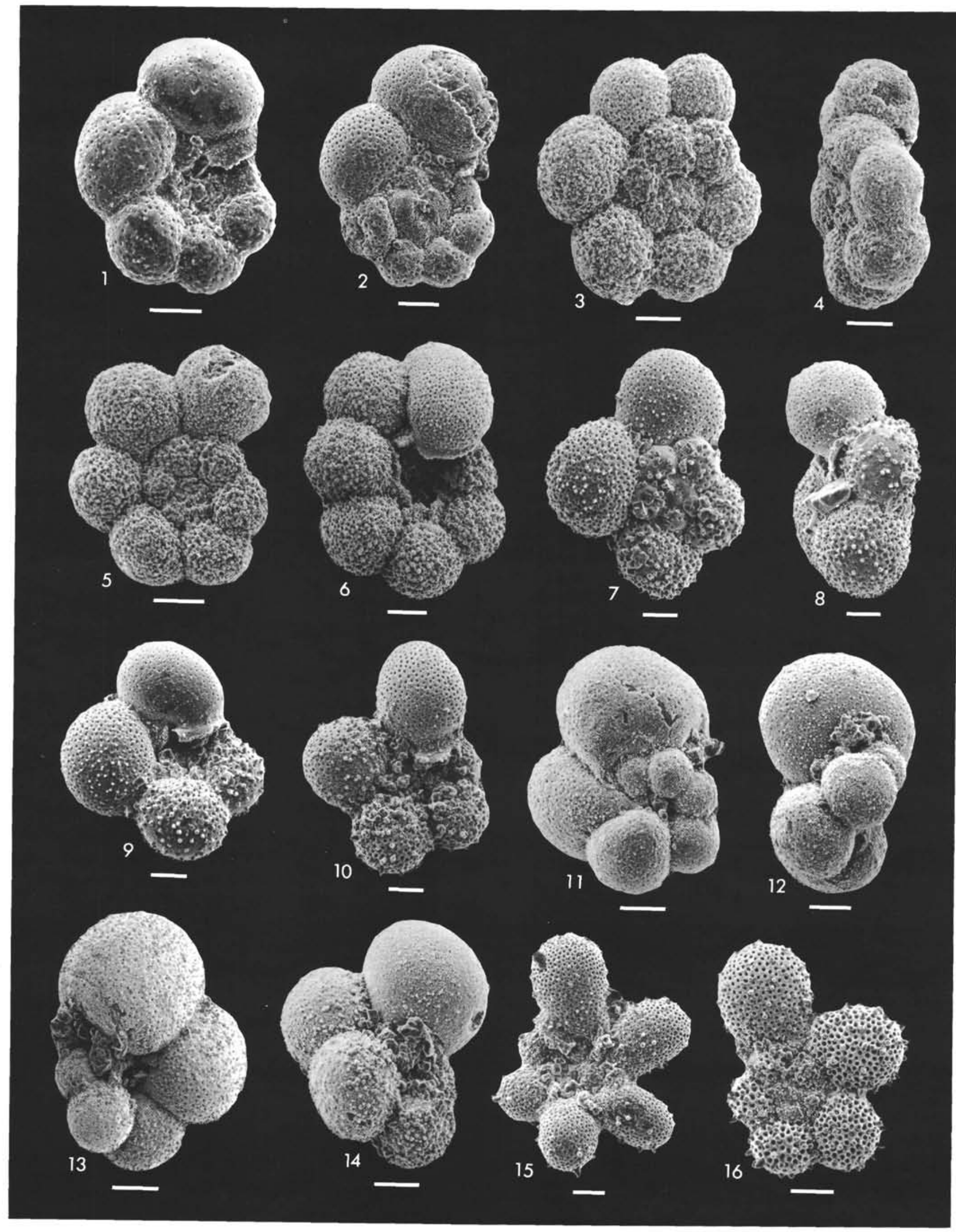




\section{PLATE 19}

Figures 1-3 Clavihedbergella simplex (Morrow). Scale $100 \mu \mathrm{m}$.

1. Spiral view. Sample 415A-9-1, 88-90 cm.

2. Peripheral view of same specimen.

3. Umbilical view. Sample 415A-8, CC.

Figures 4-8 Praeglobotruncana delrioensis (Plummer).

4. Spiral view. Sample 415 A-8, CC. Scale 60 $\mu \mathrm{m}$.

5. Umbilical view. Sample $415 \mathrm{~A}-8, \mathrm{CC}$. Scale $100 \mu \mathrm{m}$.

6. Peripheral view. Sample 415A-11, CC, 13-15 $\mathrm{cm}$. Scale $60 \mu \mathrm{m}$.

7. Spiral view. Sample $415 \mathrm{~A}-11, \mathrm{CC}, 13-15 \mathrm{~cm}$. Scale $100 \mu \mathrm{m}$.

8. Umbilical view. Sample 415A-11, CC, 13-15 $\mathrm{cm}$. Scale $60 \mu \mathrm{m}$.

Figures 9-11 Praeglobotruncana stephani (Gandolfi).

Sample 415A-9, CC. Scale $100 \mu \mathrm{m}$.

9. Spiral view.

10. Peripheral view.

11. Umbilical view.

Figure 12 Rotalipora appenninica (O. Renz).

Umbilical view. Sample 415A-10-2, 17-19 cm.

Scale $200 \mu \mathrm{m}$.

Figures 13-16 Rotalipora cushmani (Morrow).

Sample 415A-11, CC, $13-15 \mathrm{~cm}$. Scale $100 \mu \mathrm{m}$.

13. Spiral view.

14. Peripheral view of same specimen.

15. Umbilical view.

16. Peripheral view of same specimen. 

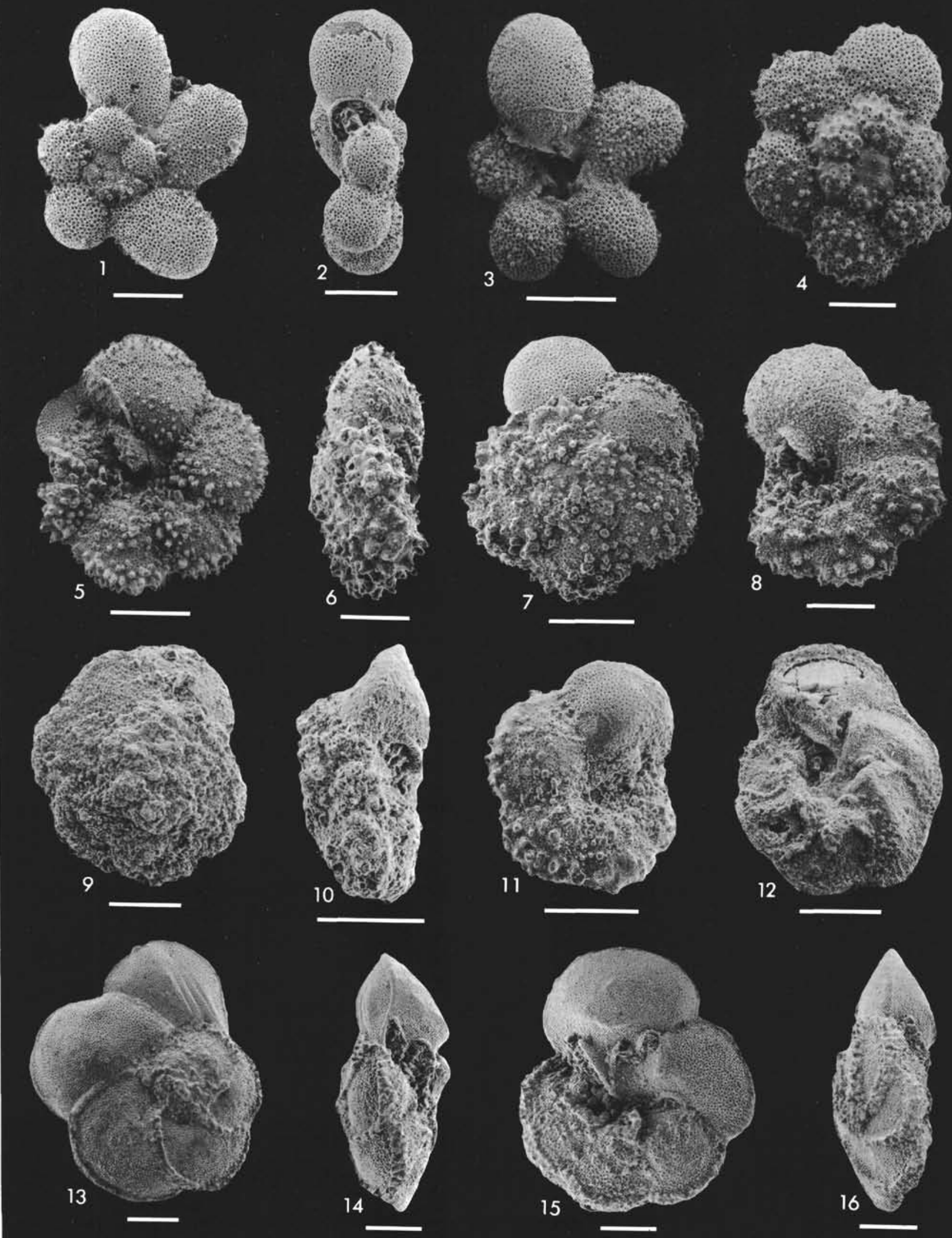


\section{PLATE 20}

Figures 1, 2 Rotalipora cushmani (Morrow).

Sample 415A-11, CC, 13-15 cm. Scale $100 \mu \mathrm{m}$.

1. Spiral view.

2. Umbilical view of same specimen.

Figures 3-6 Rotalipora evoluta Sigal.

Sample 415A-11, CC, 13-15 cm. Scale $100 \mu \mathrm{m}$.

3. Spiral view.

4. Peripheral view of same specimen.

5. Spiral view.

6. Umbilical view of same specimen.

Figures 7-12 Trocholina infragranulata Noth.

Sample 416A-27-4, 135-137 cm.

7. Spiral view. Scale $100 \mu \mathrm{m}$.

8. Umbilical view of same specimen. Scale 100 $\mu \mathrm{m}$.

9. Spiral view. Scale $60 \mu \mathrm{m}$.

10. Peripheral view. Scale $60 \mu \mathrm{m}$.

11. Umbilical view of specimen in Figure 9. Scale $60 \mu \mathrm{m}$.

12. Umbilical view. Scale $60 \mu \mathrm{m}$.

Figures 13, 14 Trocholina conica (Schlumberger).

Sample 416A-54, CC. Scale $30 \mu \mathrm{m}$.

13. Umbilical view.

14. Peripheral view of same specimen.

Figures 15, 16 Trocholina valdensis (Reichel).

Sample 416A-43-2, 30-32 cm. Scale $30 \mu \mathrm{m}$.

15. Umbilical view.

16. Peripheral view of same specimen. 


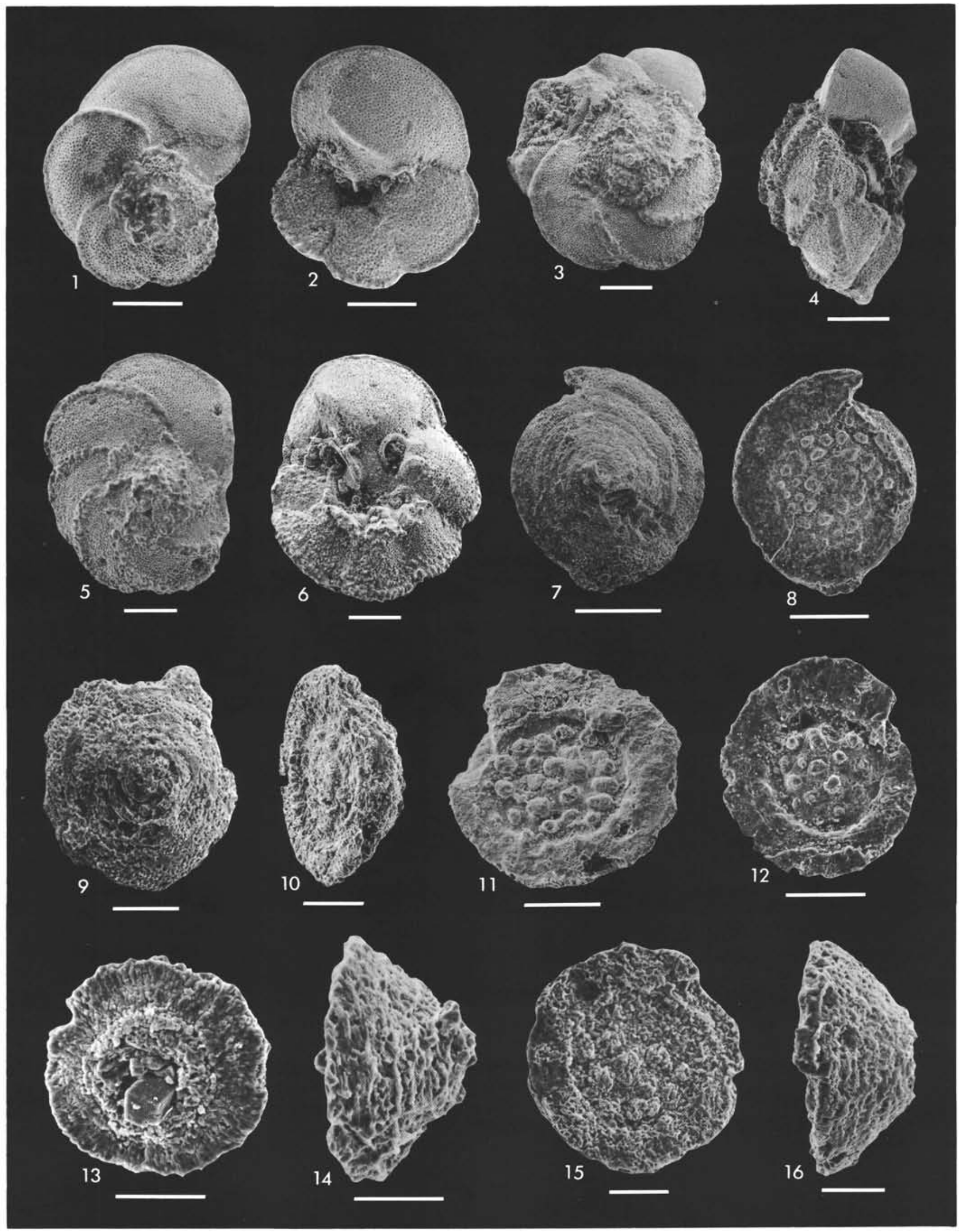




\section{PLATE 21}

Figures 1-3 Trocholina valdensis (Reichel). Scale $30 \mu \mathrm{m}$.

1. Spiral view of specimen on Plate 20, Figures 15-16. Sample 415A-43-2, 30-32 cm.

2. Peripheral view. Sample $416 \mathrm{~A}-43-2,30-32 \mathrm{~cm}$.

3. Umbilical view. Sample $416 \mathrm{~A}-40-4,83-85 \mathrm{~cm}$.

Figures 4-6 Gavelinella barremiana Bettenstaedt. Sample 416A-12-2, 144-146 cm.

4. Spiral view. Scale $30 \mu \mathrm{m}$.

5. Spiral view. Scale $50 \mu \mathrm{m}$.

6. Umbilical view. Scale $30 \mu \mathrm{m}$.

Figures 7, 8 Gavelinella intermedia (Berthelin).

Sample 416A-6, CC. Scale $60 \mu \mathrm{m}$.

7. Spiral view.

8. Umbilical view.

Figures 9-13 Conorboides hofkeri (Bartenstein and Brand). Scale $100 \mu \mathrm{m}$.

9. Spiral view. Sample 416A-45-1, 30-31 cm.

10. Peripheral view of same specimen.

11. Umbilical view of same specimen.

12. Peripheral view. Sample 416A-22-3, 108-109 cm.

13. Umbilical view of same specimen.

Figures 14-16 Conorboides valendisensis (Bartenstein and Brand).

Sample 416A-30-3, 143-144 cm. Scale $30 \mu \mathrm{m}$.

14. Spiral view.

15. Peripheral view of same specimen.

16. Umbilical view of same specimen.

\section{PLATE 22}

Figures 1-6 Epistomina anterior Bartenstein and Brand. Scale $100 \mu \mathrm{m}$.

1. Spiral view. Sample 416 A-48, CC.

2. Peripheral view of same specimen.

3. Umbilical view of same specimen.

4. Spiral view. Sample 416A-41-4, 15-17 cm.

5. Umbilical view of same specimen.

6. Peripheral view of same specimen.

Figures 7, 8 Epistomina coracolla (Roemer).

Sample 416A-11-1, 57-59 cm.

7. Spiral view. Scale $100 \mu \mathrm{m}$.

8. Umbilical iew of same specimen. Scale $90 \mu \mathrm{m}$.

Figures 9, 10 Epistomina sp. cf. E. carpenteri (Reuss).

Sample 416A-38, CC. Scale $100 \mu \mathrm{m}$.

9. Spiral view.

10. Peripheral view of same specimen.

Figures 11, Epistomina uhlgi Mjatliuk.

13-15 Sample 416A-55-2, 7-9 cm. Scale $100 \mu \mathrm{m}$.

11. Spiral view.

13. Spiral view.

14. Peripheral view.

15. Umbilical view.

Figures 12, 16 Epistomina sp.

Sample 416A-40-5, 34-36 cm. Scale $100 \mu \mathrm{m}$.

12. Umbilical view.

16. Spiral view of same specimen. 
PLATE 21
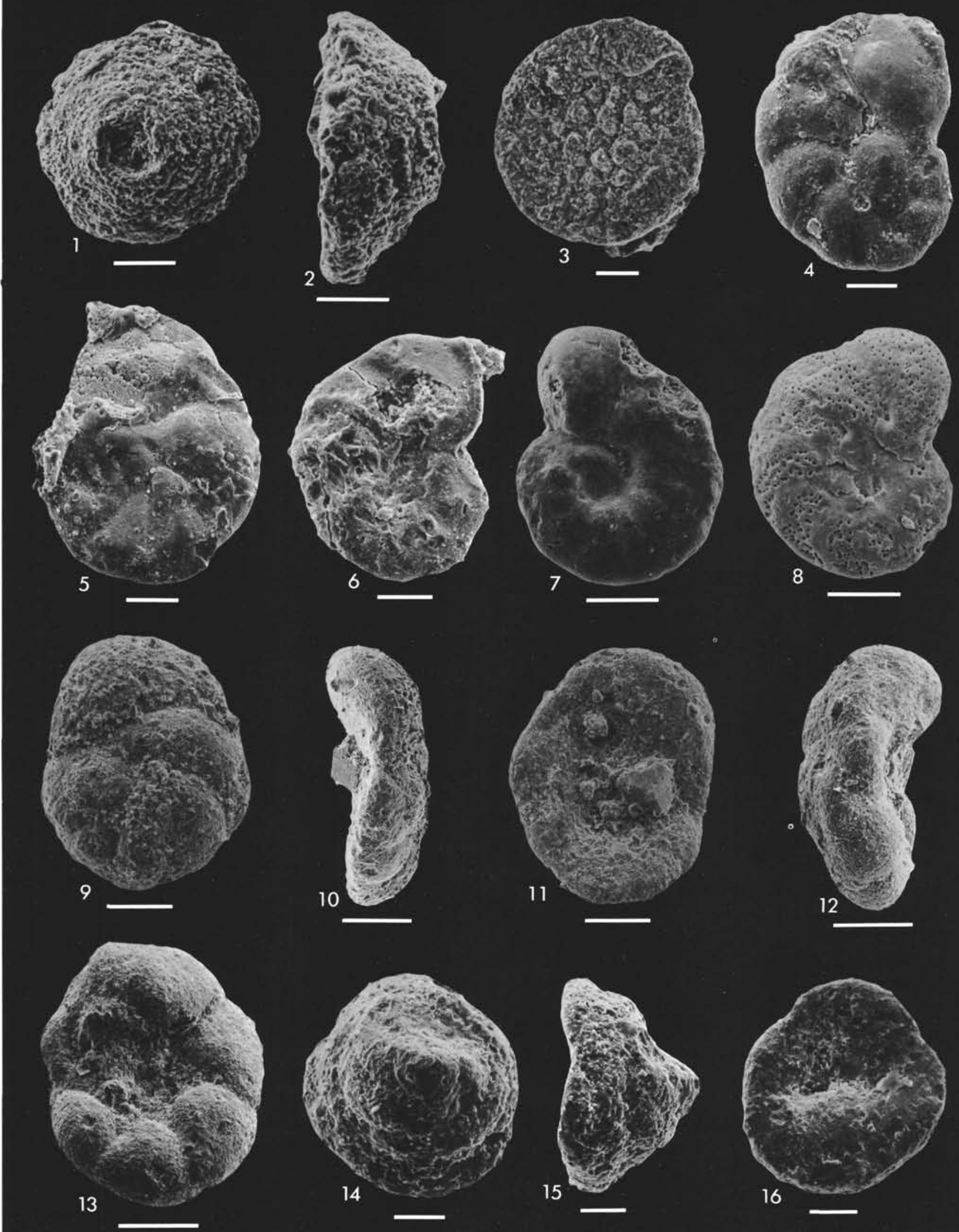

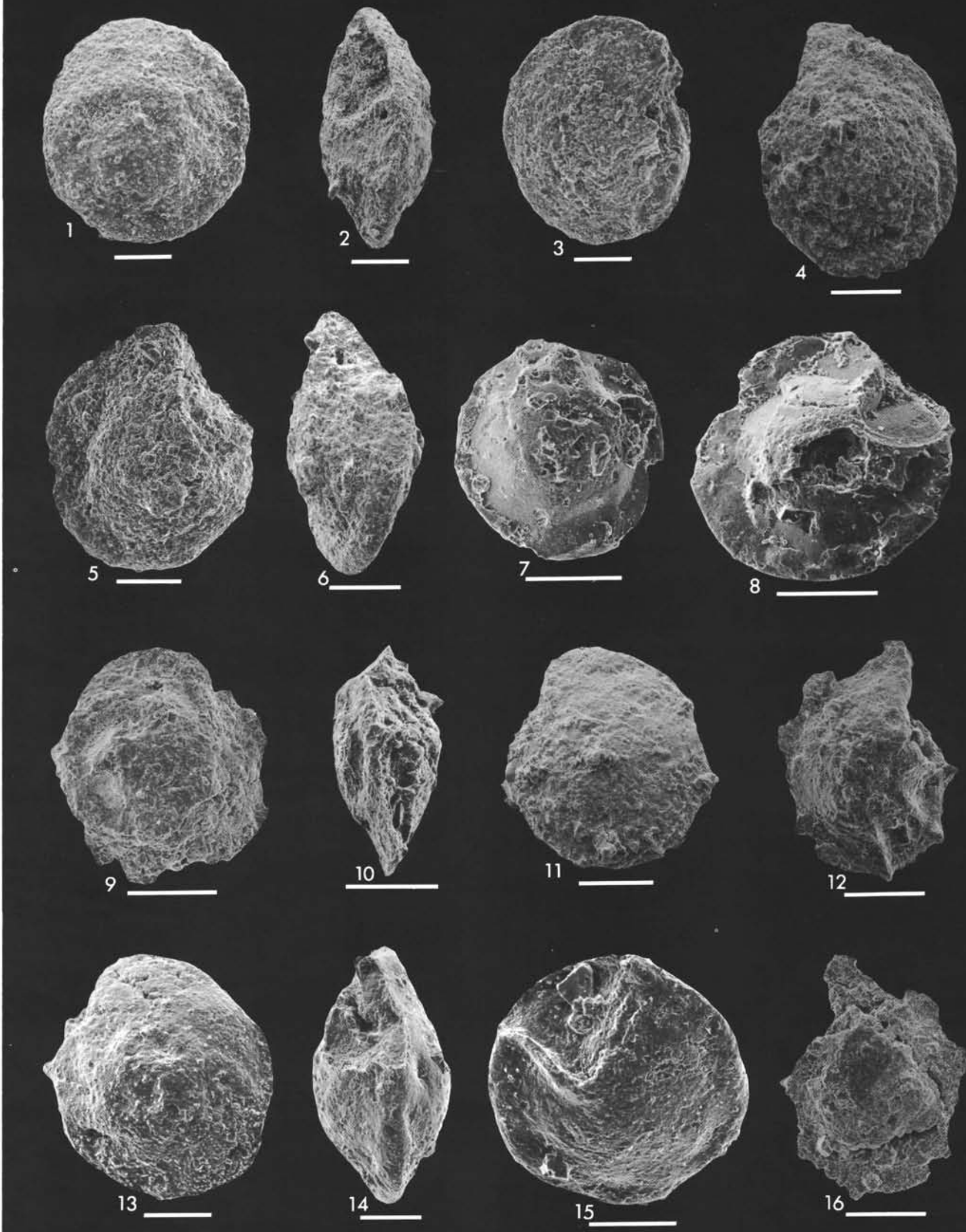
APPENDIX

List of Foraminifers from Holes $415 \mathrm{~A}$ and $416 \mathrm{~A}$

Ammobaculites(?) sp. cf. A. cuyleri Tappan Ammobaculites irregularis (Gumbel) $=$ Marginulina irregularis Gumbel Ammobaculites suprajurassicus (Schwager) $=$ Haplophragmium sup rajurassicum Schwager

Ammodiscus rotalarius Loeblich and Tappan

Astacolus calliopsis (Reuss) $=$ Margimulina calliopsis Reuss

Astacolus crepidularis $($ Roemer $)=$ Planularia crepidularis Roemer

Astacolus gratus (Reuss) $=$ Cristellaria grata Reuss

Astacolus incurvatus (Reuss) = Cristellaria incurvata Reuss

Astacolus mutilatus Espitalie and Sigal

Astacolus planiusculus (Reuss) $=$ Cristellaria planiuscula Reuss Bigenerina clavellata Loeblich and Tappan

Bigenerina jurassica (Haeusler) $=$ Pleurostomella jurassica Haeusler

Citharina complanata perstriata $($ Tappan $)=$ Vaginulina complanate perstriata Tappan

Citharina intumescens (Reuss) $=$ Vaginula intumescens Reuss

Clavihedbergella simplex (Morrow) $=$ Hastigerinella simplex Morrow Conorboides hofkeri (Bartenstein and Brand) $=$ Conorbis hofkeri Bartenstein and Brand

Conorboides valendisensis (Bartenstein and Brand) $=$ Conorbis yalendisensis Bartenstein and Brand

Dentalina communis d'Orbigny

Dentalina cylindroides Reuss

Dentalina distincta Reuss

Dentalina ejuncida Loeblich and Tappan

Dentalina gracilis d'Orbigny

Dentalina guttifera d'Orbigny

Dentalina jureesis (Gomber) $=$ Vagir

Dentalina nana Reuss

Dentalina pseudonana ten Dam

Dentalina soluta Reuss

Dentalina torta Terquem

Dentalina varians Terquem

Dorothia cornula (Reuss) = Textularia cornulus Reuss

Dorothia flifformis (Berthelin) $=$ Gaudryina filiformis Berthelin

Dorothia hateriviana (Moullade) $=$ Marssonella hauterivianelin

lade
Dorothia kummi (Zedler) $=$ Marssonella kummi Zedler

Dorothia praehauteriviana Dieni and Massari

Eorothia praehauteriviana Dieni and Massari

Eoguttulina oolihica (Terquem) $=$ Polymorph

Epistomina caracolla (Roemer) $=$ Gyroidina caracolla Roemer

Epistomina caracolla $($ Roemer $)=$ Gyroidina caracolla Roemer
Epistomina sp. cf. E. carpenteri $($ Reuss) $=$ Rotalia carpenteri Reuss

Epistomina sp. cf. E. carpent

Falsoguttulina wolburgi Bartenstein and Brand

Frondicularia didyma Berthelin

Frondicularia hastata hastata Roemer

Frondicularia intermittens Reuss

Frondicularia inversa Reuss

Frondicularia inversa jeidesi Maync

Frondicularia joidesi Maync

Frondicularia simplicissima ten Dam

Gaudryina grandis (Crespin) $=$ Dorothia grandis Crespin

Gaudryina grandis (Crespin) $=$ Dorothia grandis Crespin

Mjotlink

Gavelinella barremiana Bettenstaedt

Gavelinella intermedia (Berthelin) $=$ Anomalina intermedia Berthelin

Globigerinelloides bentonensis (Morrow) $=$ Anomalina bentonensis Morrow

Globigerinelloides caseyi (Bolli, Loeblich, and Tappan) = Planoma

lina caseyi Bolli, Loeblich, and Tappan

Globulina exserta (Berthelin) = Polymorphina exserta Berthelin

Globulina prisca Reuss

Glomospira variabilis (Kubler and $\mathrm{Z}$ wingli) $=$ Cornuspira variabilis

Kubler and Zwingli

Glomospirella gaultina (Berthelin) $=$ Ammodiscus gaultinus Berthelin

Gubkinella graysonensis (Tappan) $=$ Globigerina graysonensis Tappan

Guembelitria cenomana (Keller) = Gümhelina cenomana Keller

Haplophragmoides concavus $($ Chapman) $=$ Trochammina concava Chapman

Haplophragmoides haeusleri Lloyd

Haplophragmoides nonioninoides (Reuss) $=$ Haplophragmium nonioninoides Reuss

Haplophragmium aequale $($ Roemer) $=$ Spirolina aequalis Roemer

Haplophragmium inconstans erectum Bartenstein and Brand

Hedbergella delrioensis $($ Carsey $)=$ Globigerina cretacea d'Orbigny var, delrioensis Carsey

Hedbergella sp. cf. $\boldsymbol{H}$. delrioensis (Carsey)

edbergella infracretacea (Glaessner) = Globigerina infracretace Glaessner
Hedbergella planispira $($ Tappan $)=$ Globigerina planispira Tappan Hedbergella simplicissima (Magné and Sigal) $=$ Hastigerinella sim . plicissima Magnt and Sigal

Heterohelix moremani (Cushman) $=$ Guembelina moremani Cush. man

ippocrepina depressa Vasicek

Lagena globosa gaultina ten Dam

Lagena hauteriviana cylindracea Bartenstein and Brand

Lagena hauteriviana hauteriviana Bartenstein and Brand

Lagena laevis (Montagu) $=$ Vermiculum laeve Montagu

Lagena sp. cf. $L$. meridionalis Wiesner

Lagena ovata $($ Terquem $)=$ Oolina ovata Terquem

Lagena oxystoma Reuss

agena sulcata (Walker and Jacob) $=$ Serpula (Lagena) sulcata

Walker and Jacob

Lagena sztejnae Dieni and Massar

Lenticulina busnardoi Moullade

Lenticulina eichenbergi Bartenstein and Brand

Lenticulina gaultina $($ Berthelin) $=$ Cristellaria gaultina Berthelin

Lenticulina guttata $($ ten Dam) $=$ Planularia guttata ten Dam

Lenticulina muensteri (Roemer) $=$ Robulina munsteri Roemer

Lenticulina nodosa (Reuss) $=$ Robulina nodosa Reuss

enticulina ouachensis multicella Bartenstein, Bettenstaedt, and

Boll

Lenticulina ouachensis ouachensis $($ Sigal) $=$ Cristellaria ouachensis Sigal

Lenticulina praegaultina Bartenstein, Bettenstaedt, and Boll

enticulina subalata (Reuss) $=$ Cristellaria subalata Reuss

Lenticulina subangulata (Reuss) $=$ Cristellaria subangulata Reuss

Lenticulina turgidula (Reuss) = Cristellaria turgidula Reuss

Lingulina lamellata Tappan

Lingulina loryi $($ Berthelin $)=$ Frondicularia loryi Berthelin

Lingulina nodosaria Reuss

Lingulina pupa $($ Terquem) $=$ Marginulina pupa Terquem

Lingulina semiornata Reuss

Lituotuba sp. cf. L. nothi (Majzon) $=$ Thalmannina nothi Majzon

arginulinopsis bettenstaedti $($ Bartenstein and Brand $)=$ Lenticulin

(Marginulinopsis) bettenstaedti Bartenstein and Brand

Margimulinopsis cephalotes (Reuss) $=$ Cristellaria cephalotes Reuss

Margimulinopsis collignoni (Epistalit and Sigal) $=$ Lenticulina col

lignoni Epistalie and Sigal

Marginulinopsis parkeri (Reuss) $=$ Marginulina parkeri Reuss

Massiline sp. cf. M. planoconvexa Tappan

Nodobacularia nodulosa (Chapman) $=$ Nubecularia nodulos Chapman

Nodosaria sp. cf. N. aspera Reuss

Nodosaria sp. cf. $N$. chapmani Tappan

Nodosaria obscura Reuss

Nodosaria paupercula Reuss

Nodosaria prismatica Reuss

Nodosaria sceptrum Reuss

Nodosaria zippei Reuss

pthalmidium sp. cf. $O$. carinatum (Kubler and Zwingli) $=$ Oculin carinatum Kubler and Zwingl

Patellina feifeli (Paalzow) $=$ Trocholina feifeli Paalzow

Patellina subcretacea Cushman and Alexander

Patellina turriculata Dieni and Massari

Praeglobotruncana delrioensis (Plummer) $=$ Globorotalia delrioensis

Prestor

Gandolfi

Psammosphaera fusca Schulze

Pseudonodosaria humilis (Roemer) $=$ Nodosaria humilis

Roemer

yrulina cylindroides $($ Roemer $)=$ Polymorphina

cylindroides Roemer

Ramulina aculeata Wright

Ramulina globotubulosa Cushman

Ramulina spandeli Paalzow

Recurvoides imperfectus (Hanzlikova) $=$ Haplophragmoides

imperfectus Hanzlikov

Reophax guttifer Brady

Reophax helveticus $($ Haeusler $)=$ Dentalina helveticus

Haeusler

Reophax horridus $($ Schwager $)=$ Haplostiche horrida Schwager

Reophax minuta Tappan

Reophax multilocularis Haeusler

Reophax pilulifer Brady

Rhizammina indivisa Brady

Rotalipora appenninica $(\mathrm{O}, \mathrm{Renz})=$ Globotruncana appenninice

O. Renz

Rotalipora cushmani (Morrow) $=$ Globorotalia cushmani Morrow Rotalipora evoluta Sigal

Saccammina lathrami Tappan

Saracenaria compacta Epistalie and Sigal
Saracenaria cushmani Tappan

Saracenaria saxkeica saxonica (Bartenstein and Brand) $=$ Len-

ticulina (Lenticulina) saxonica saxonica Bartenstein and Brand

Schackoina cenomana $($ Schacko) $=$ Siderolina cenomana Schacko

Schackoina multispinata (Cushman and Wickenden) $=$ Hantkenina multispinata Cushman and Wickenden

Spirillina elongoto Bielecka and Pozaryski

Spirillina minima Schacko

Spirillina tenuissima Go

Spiroloculina duestensis Bartenstein and Brand

Spiroplectammina ammovitrea Tappan

Spiroplectammina longa Lalicker

Spiroplectammina sp. cf. S. obscura Said and Barakat

Spiroplectinata complanata (Reuss) $=$ Proroporus complinatus

Reuss

Textularia cordiformis Schwager

Textularia foeda Reuss

Triloculina meotica Loeblich and Tappan

Tristix acutangula (Reuss) = Rhabdogonium acutangulum Reuss

Tristix excavata (Reuss) $=$ Rhabdogonium excavatum Reuss

Tristix lanceola Sliter, n. sp.

Tristaxia subrotunda ten Dam

Trochammina globigeriniformis (Parker and Jones) = Lituola

nautiloidea var. globigeriniformis Parker and Jones

Trochammina neocomiana Mjatliuk

Trochammina quinqueloba Geroch

Trochamina suprajurassica Seibol.

Trochammina umialensis Tappan

Scholina conica (Schlumberger) $=$ Involutina conica

Schlumberger

Trocholina infragranulata Noth

Trocholina valdensis $($ Reichel) $=$ Neotrocholina valdensis Reichel

Turrispirillina conoidea (Paalzow) = Spirillina conoidea Paalzow

aginulina angustissima Reuss

aginulina debilis $($ Berthelin $)=$ Marginulina debilis Berthelin

Vaginulina gaultina Bertheli

Vaginulina recta Reuss

ginulinopsis excentrica $($ Cornuel) $=$ Cristellaria excentrica

Cornuel

Vaginulinopsis matutina (d'Orbigny) $=$ Cristellaria matutina

d'Orbigny
Vaginulinopsis pseudodebilis (Dieni and Massari) $=$ Marginulina pseudodebilis Dieni and Massari

Vaginulinopsis reticulosa ten Dar

Vaginulinopsis schloenbachi (Reuss) $=$ Cristellaria schloenbachi
Reuss

APPENDIX 2

Barren Samples or Those with Non-diagnostic Foraminifer Faunas from Hole 416A

\begin{tabular}{lll}
\hline \multicolumn{1}{c}{ Sample } & \multicolumn{1}{c}{ Sample } & \multicolumn{1}{c}{ Sample } \\
\hline $416 \mathrm{~A}-7-2,15-19$ & $416 \mathrm{~A}-23-4,16-17$ & $416 \mathrm{~A}-41-5,3-5$ \\
$416 \mathrm{~A}-7-2,83-85$ & $416 \mathrm{~A}-24-1,65-67$ & $416 \mathrm{~A}-41-5,26-28$ \\
$416 \mathrm{~A}-9-1,85-86$ & $416 \mathrm{~A}-24-2,128-130$ & $416 \mathrm{~A}-42-1,41-43$ \\
$416 \mathrm{~A}-11-2,110-112$ & $416 \mathrm{~A}-25, \mathrm{CC}$ & $416 \mathrm{~A}-42-2,109-111$ \\
$416 \mathrm{~A}-11-3,2-4$ & $416 \mathrm{~A}-26-3,129-131$ & $416 \mathrm{~A}-42-3,97-99$ \\
$416 \mathrm{~A}-12-1,83-85$ & $416 \mathrm{~A}-26, \mathrm{CC}$ & $416 \mathrm{~A}-42, \mathrm{CC}$ \\
$416 \mathrm{~A}-13-2,63-65$ & $416 \mathrm{~A}-27, \mathrm{C}$ & $416 \mathrm{~A}-43-3,34-36$ \\
$416 \mathrm{~A}-14-3,78-79$ & $416 \mathrm{~A}-28-4,83-85$ & $416 \mathrm{~A}-44-1,102-104$ \\
$416 \mathrm{~A}-15-2,144-146$ & $416 \mathrm{~A}-29-1,4-6$ & $416 \mathrm{~A}-45-2,127-129$ \\
$416 \mathrm{~A}-15-3,20-22$ & $416 \mathrm{~A}-30-1,145-147$ & $416 \mathrm{~A}-45-2,57-59$ \\
$416 \mathrm{~A}-15-4,118-120$ & $416 \mathrm{~A}-30-4,147-148$ & $416 \mathrm{~A}-46-1,98-100$ \\
$416 \mathrm{~A}-16-1,105-107$ & $416 \mathrm{~A}-30, \mathrm{CC}$ & $416 \mathrm{~A}-46-2,90-92$ \\
$416 \mathrm{~A}-16-3,119-120$ & $416 \mathrm{~A}-32, \mathrm{CC}$ & $416 \mathrm{~A}-46-3,114-116$ \\
$416 \mathrm{~A}-16-5,27-29$ & $416 \mathrm{~A}-34-1,5-7$ & $416 \mathrm{~A}-47-1,109-111$ \\
$416 \mathrm{~A}-17-2,149-150$ & $416 \mathrm{~A}-35-2,9-10$ & $416 \mathrm{~A}-48-1,124-126$ \\
$416 \mathrm{~A}-17-4,11-13$ & $416 \mathrm{~A}-35, \mathrm{CC}$ & $416 \mathrm{~A}-48-2,59-61$ \\
$416 \mathrm{~A}-18-2,23-25$ & $416 \mathrm{~A}-36, \mathrm{CC}$ & $416 \mathrm{~A}-49-2,116-118$ \\
$416 \mathrm{~A}-18-3,49-51$ & $416 \mathrm{~A}-37-3,29-31$ & $416 \mathrm{~A}-50-1,144-146$ \\
$416 \mathrm{~A}-18-4,80-81$ & $416 \mathrm{~A}-37-3,63-65$ & $416 \mathrm{~A}-50-2,98-100$ \\
$416 \mathrm{~A}-18, \mathrm{CC}$ & $416 \mathrm{~A}-38-1,23-25$ & $416 \mathrm{~A}-50, \mathrm{CC}$ \\
$416 \mathrm{~A}-19-1,42-44$ & $416 \mathrm{~A}-38-2,6-7$ & $416 \mathrm{~A}-51-1,81-83$ \\
$416 \mathrm{~A}-19-3,54-55$ & $416 \mathrm{~A}-38-2,33-35$ & $416 \mathrm{~A}-53-1,53-55$ \\
$416 \mathrm{~A}-19-4,86-88$ & $416 \mathrm{~A}-40-2,71-73$ & $416 \mathrm{~A}-53-1,80-82$ \\
$416 \mathrm{~A}-19-5,40-42$ & $416 \mathrm{~A}-40-3,4-6$ & $416 \mathrm{~A}-53-2,17-19$ \\
$416 \mathrm{~A}-20-3,46-48$ & $416 \mathrm{~A}-40-3,91-93$ & $416 \mathrm{~A}-55-2,27-29$ \\
$416 \mathrm{~A}-21-2,149-150$ & $416 \mathrm{~A}-40-4,139-141$ & $416 \mathrm{~A}-55-2,44-47$ \\
$416 \mathrm{~A}-22-1,103-105$ & $416 \mathrm{~A}-40-6,101-103$ & $416 \mathrm{~A}-57-1,27-29$ \\
$416 \mathrm{~A}-23-1,64-66$ & $416 \mathrm{~A}-41-2,28-30$ & $416 \mathrm{~A}-57-1,104-106$ \\
$416 \mathrm{~A}-23-2,95-96$ & $416 \mathrm{~A}-41-3,110-112$ & \\
\hline & & \\
\hline
\end{tabular}


APPENDIX 3

Distribution of Jurassic and Cretaceous foraminifers at Site 416. Abundances based on total fauna recovered from 10- $\mathrm{cm}^{3}$ samples.

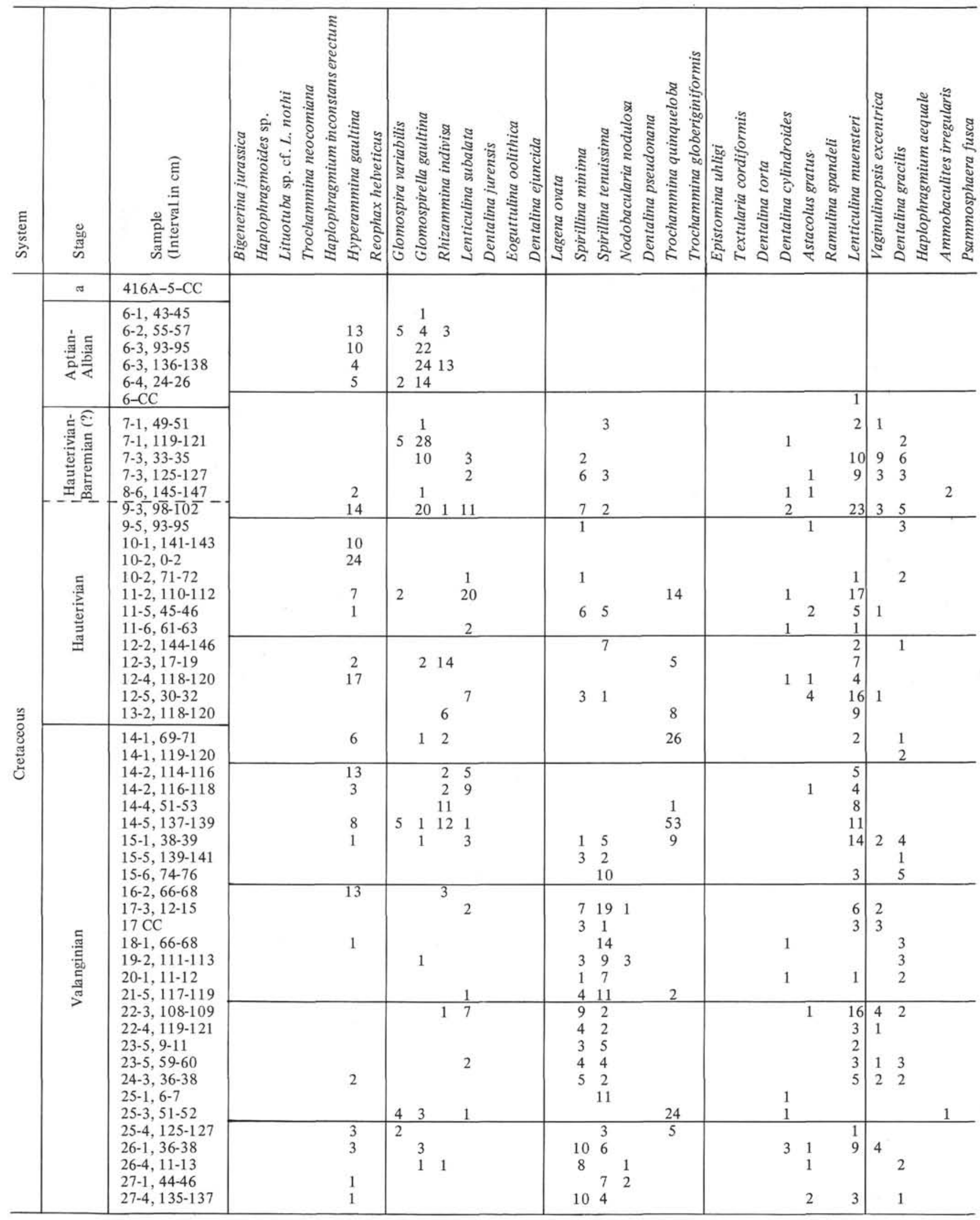




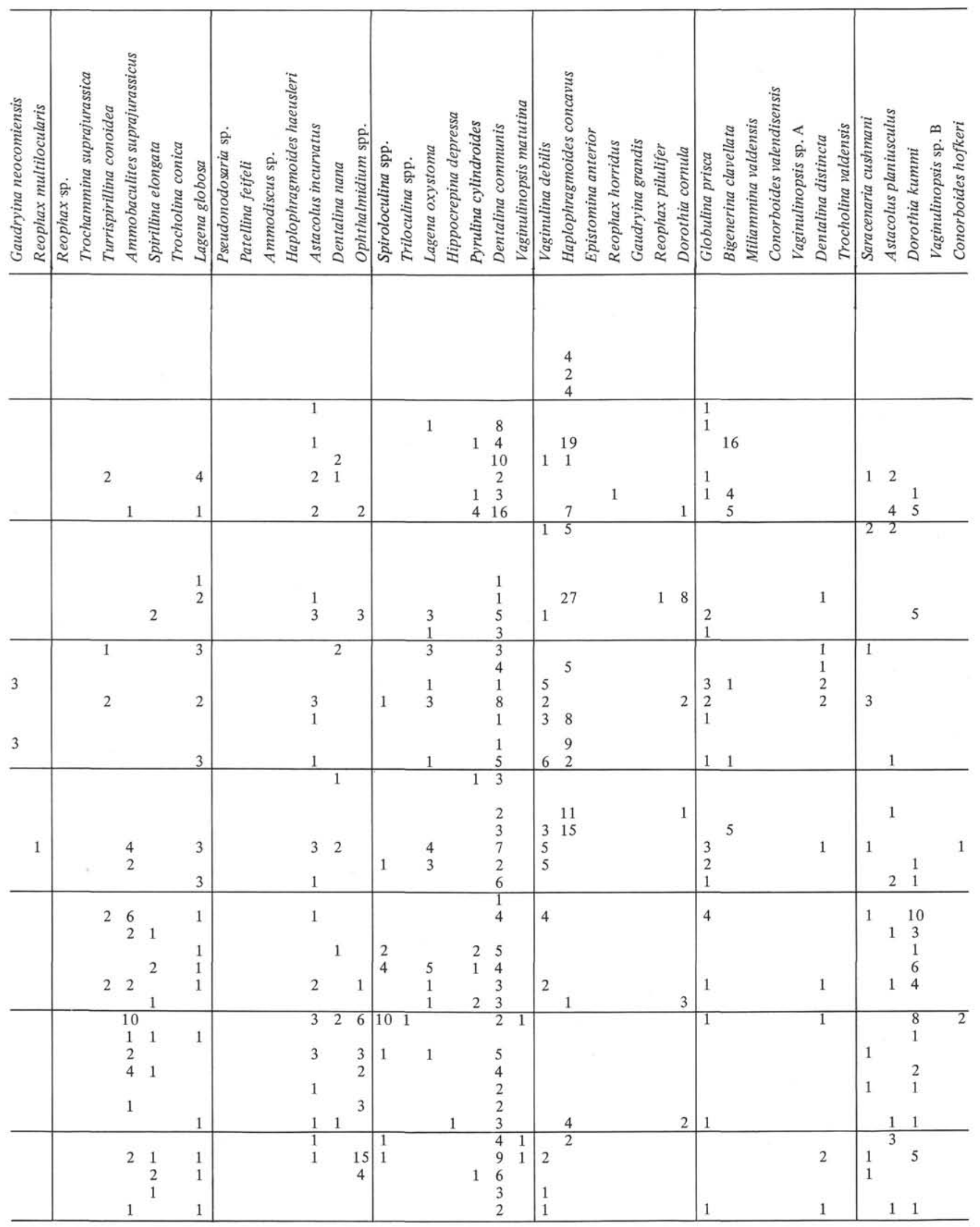


APPENDIX 3-Continued

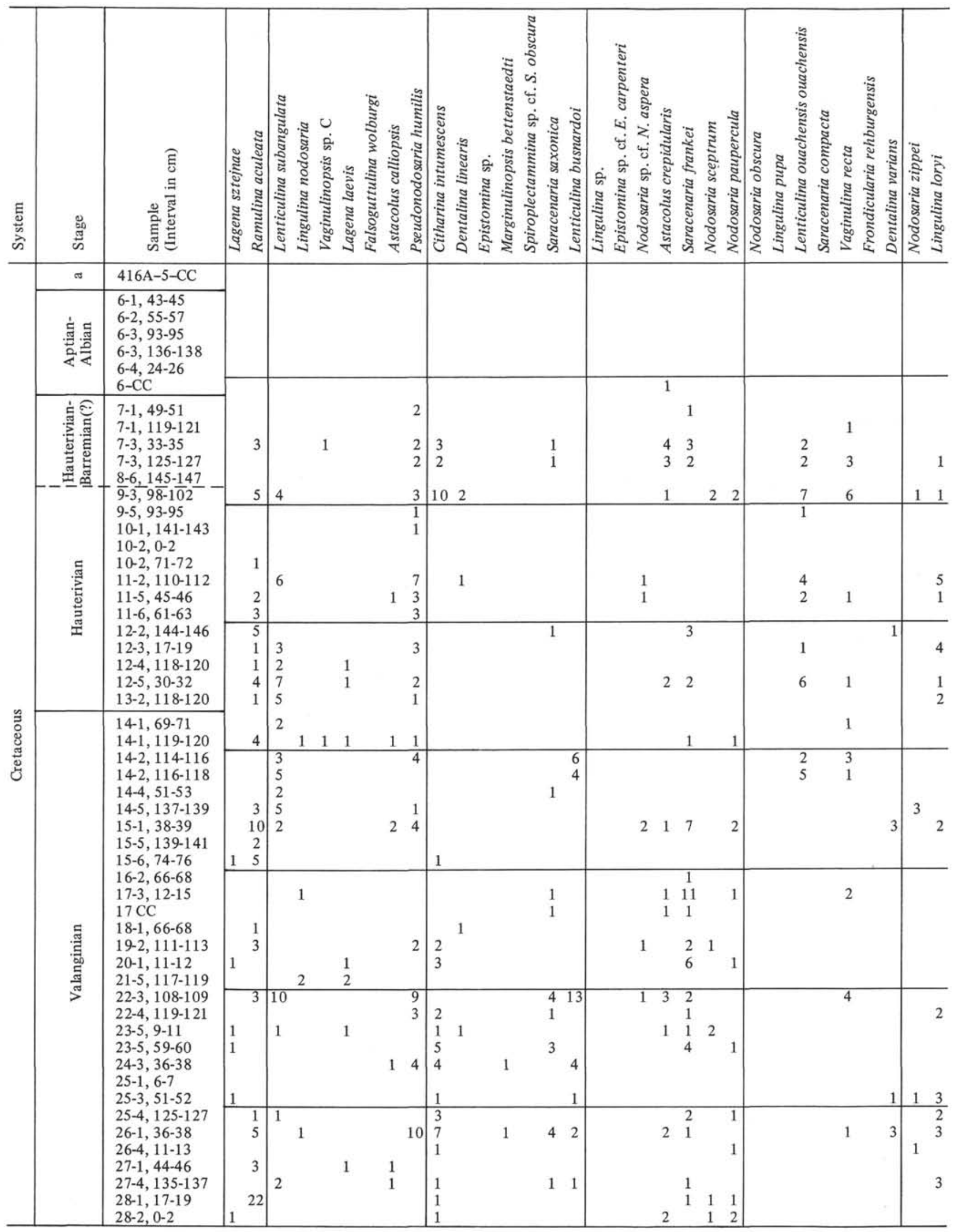


APPENDIX 3-Continued

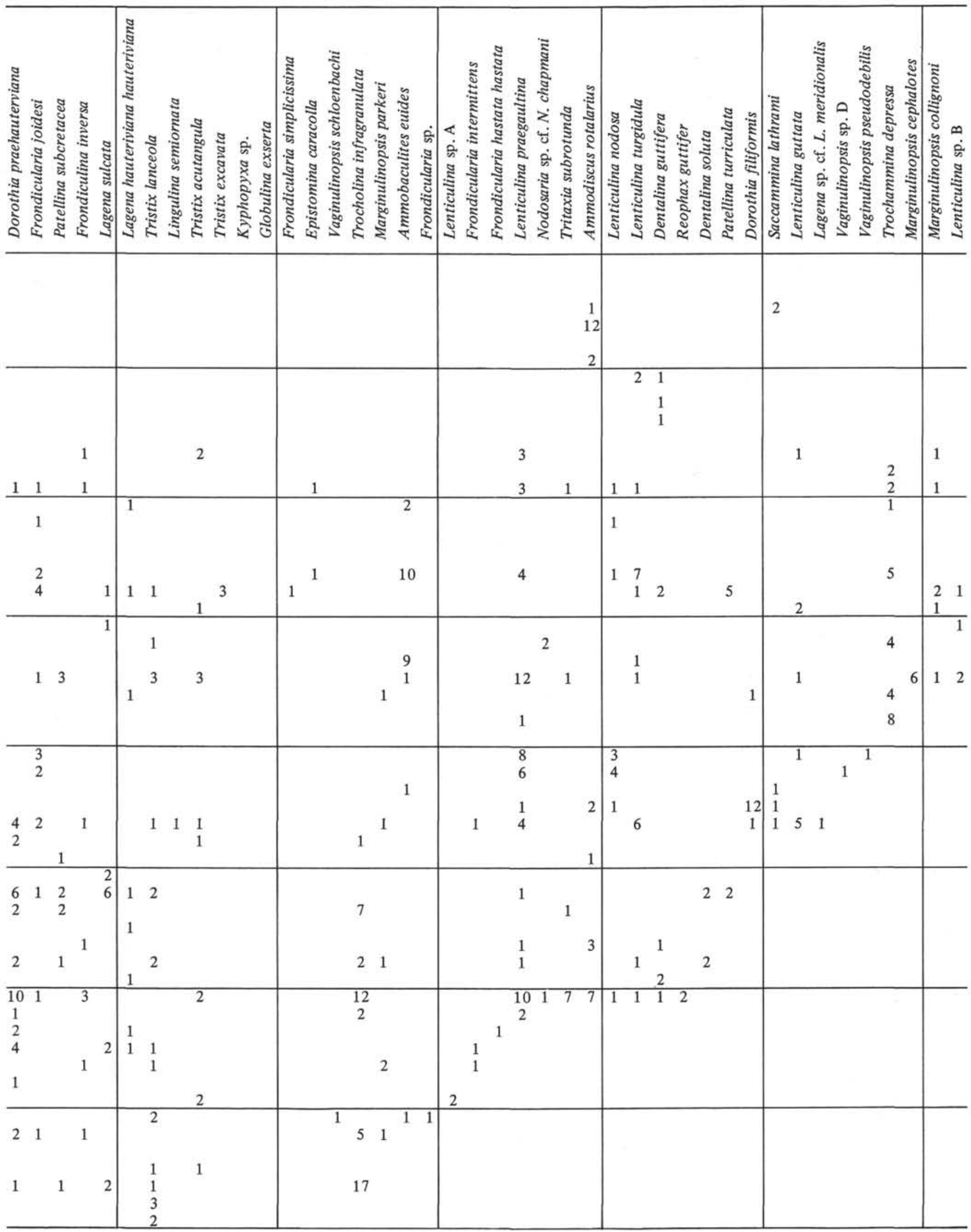




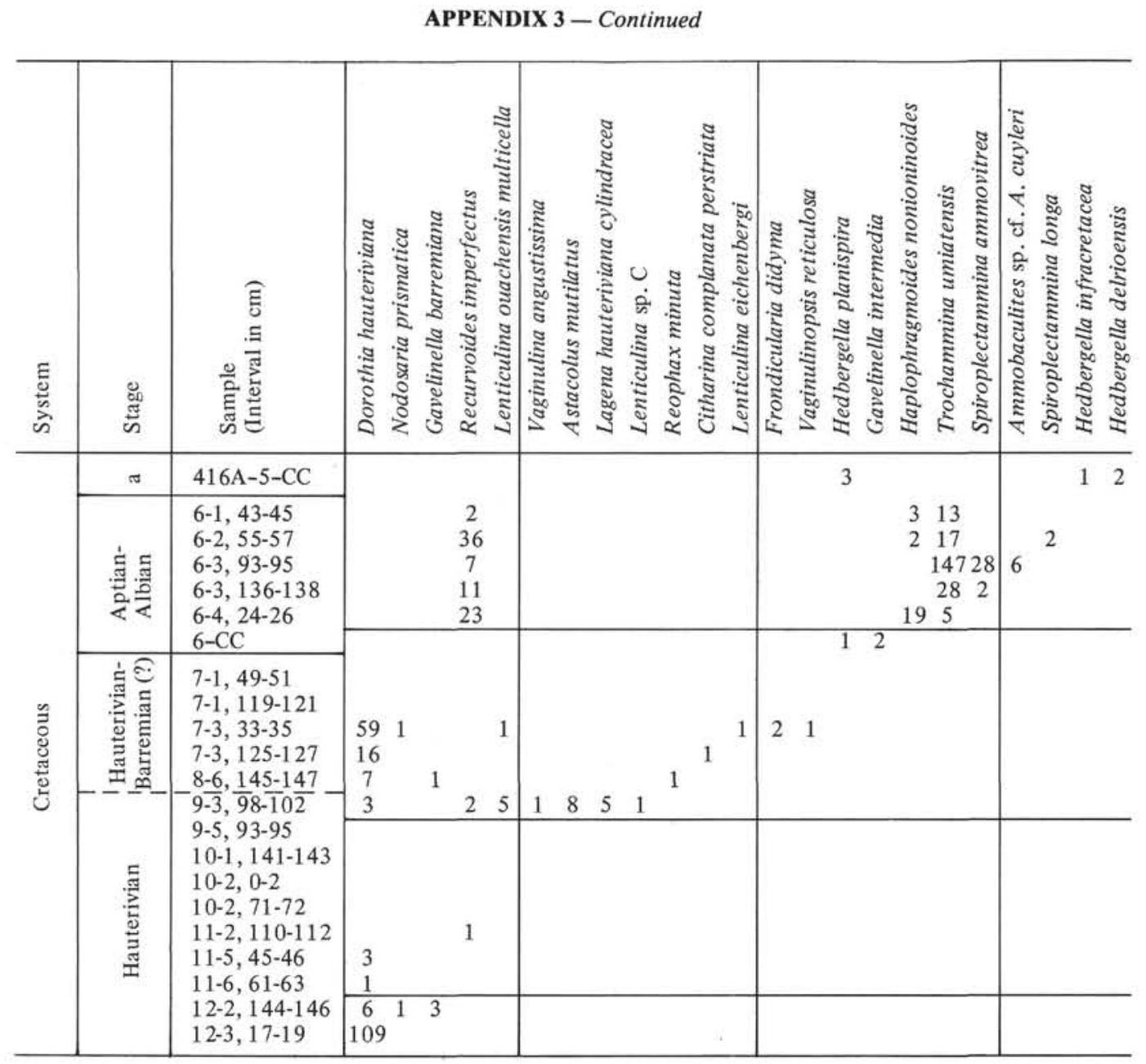

${ }^{a}$ Albian-Cenomanian

$\mathrm{b}_{\text {fine sand }}$

$\mathrm{c}_{\text {coarse sand }}$ 

APPENDIX 3 - Continued

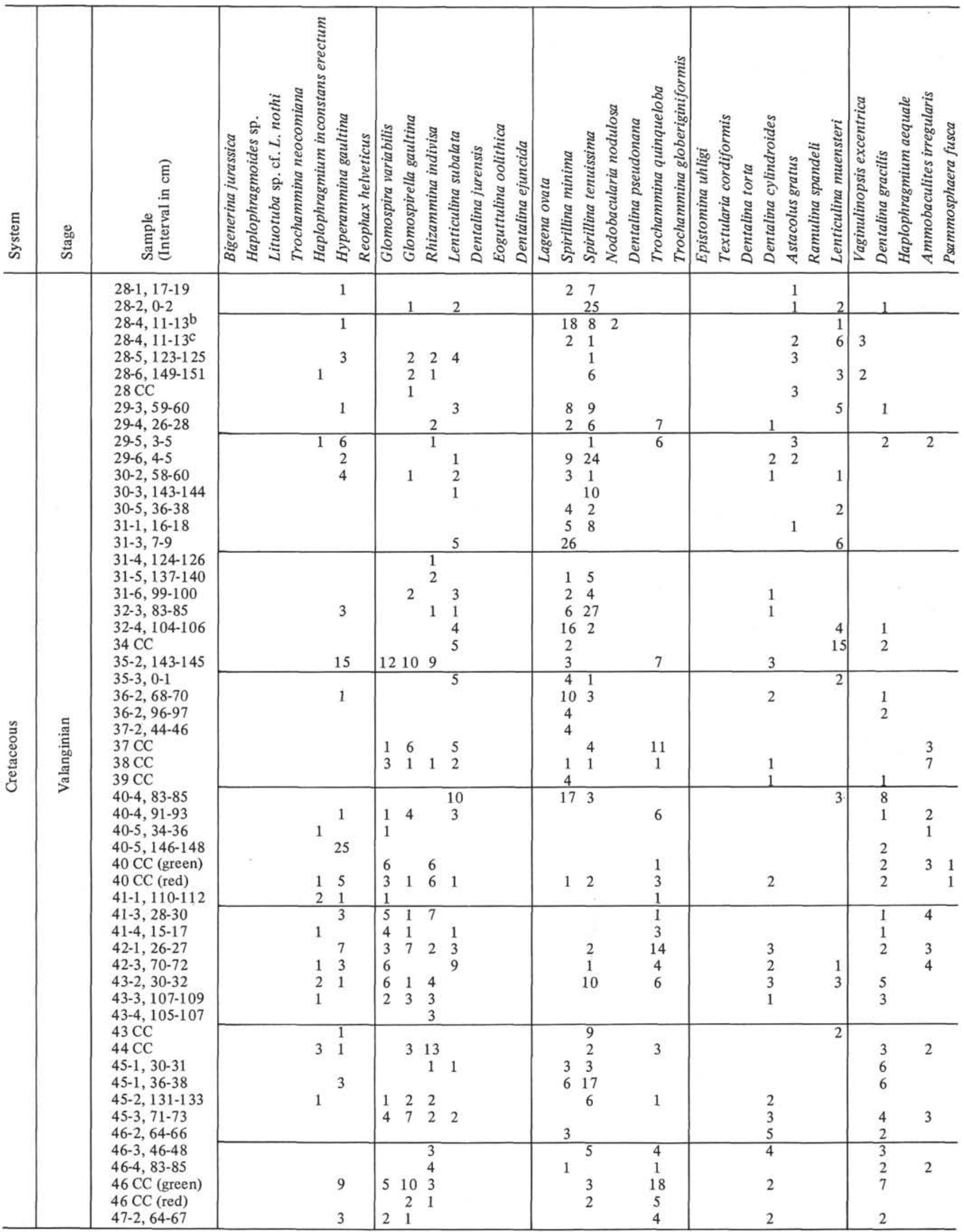




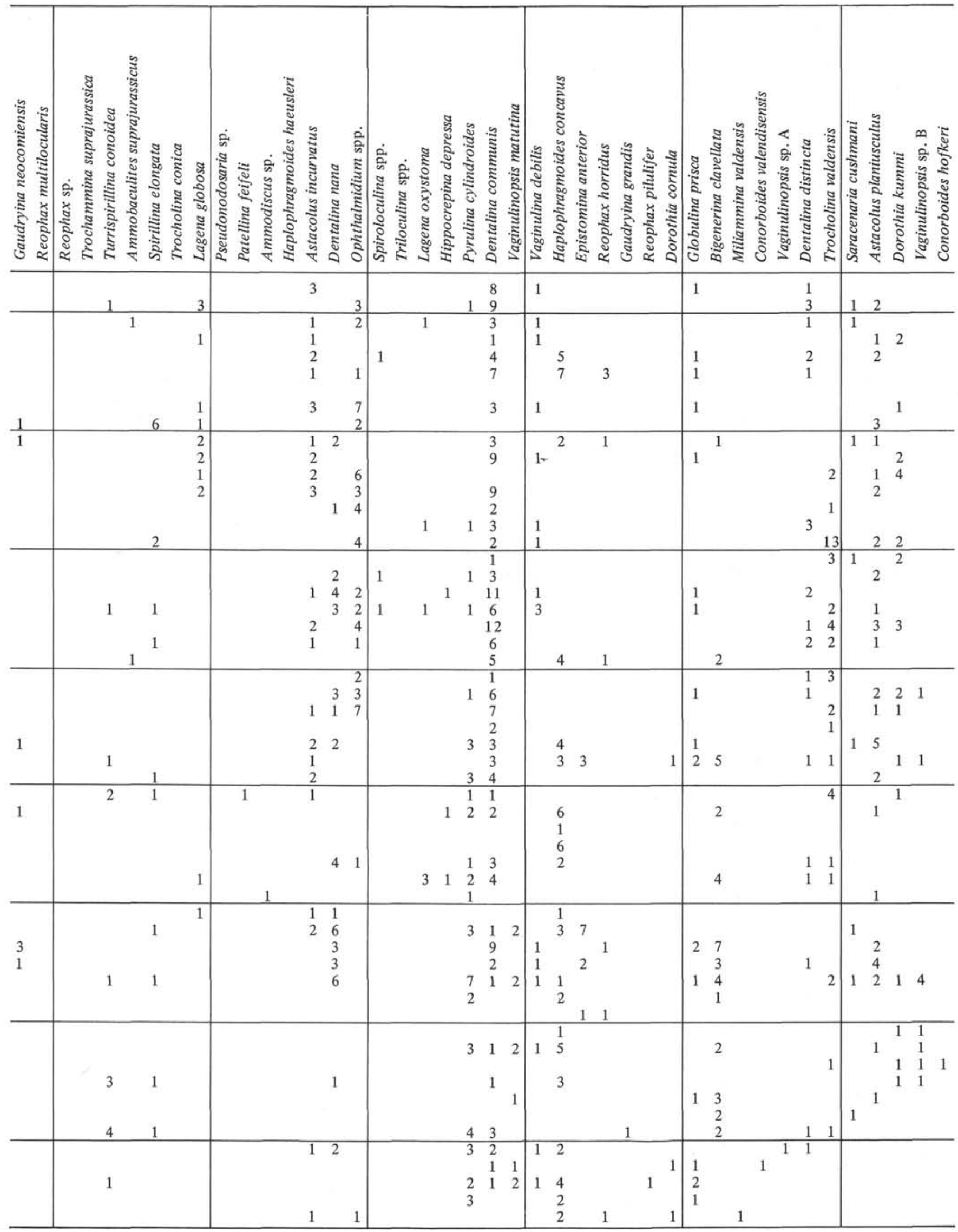


APPENDIX 3-Continued

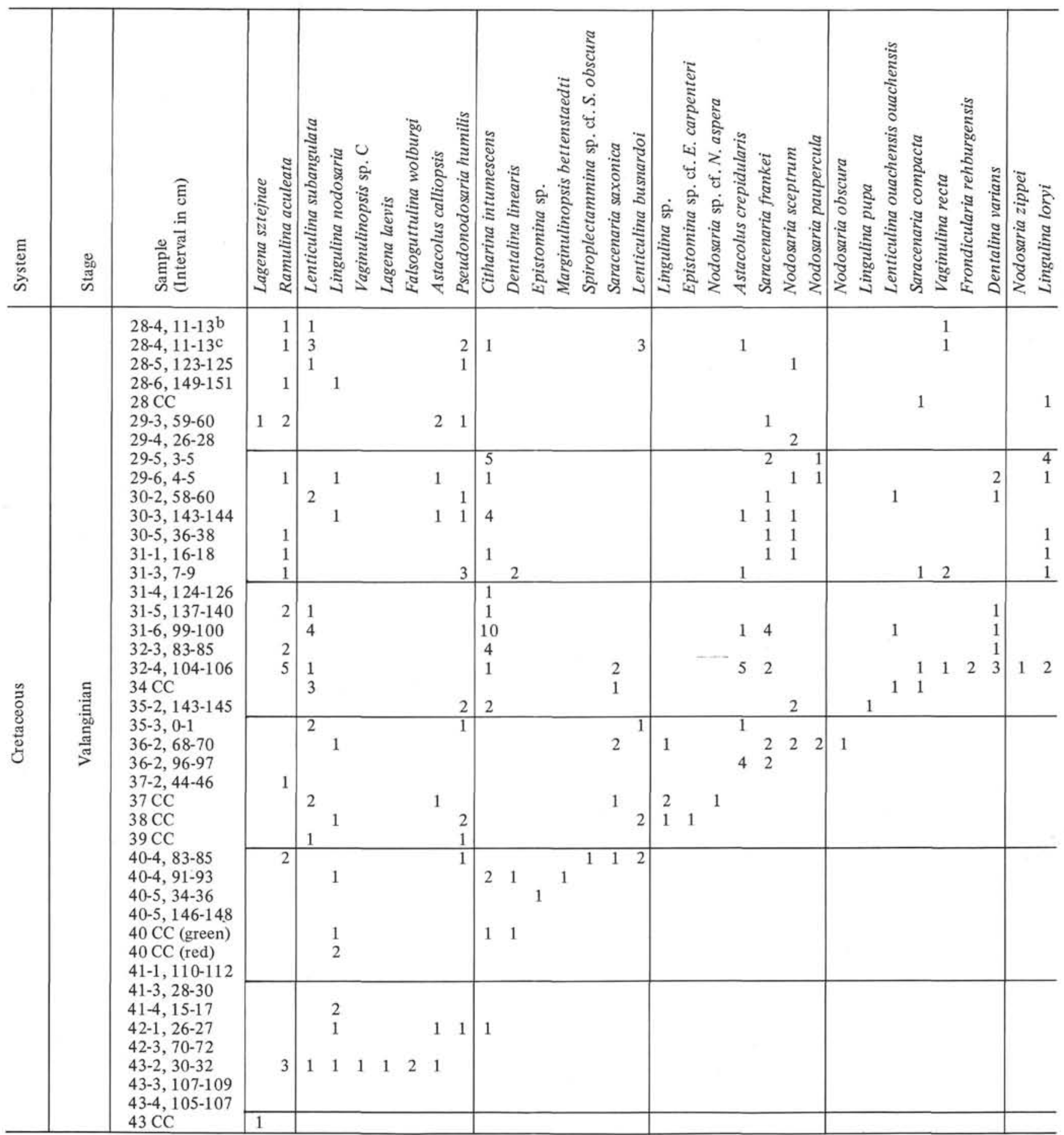


MESOZOIC FORAMINIFERS

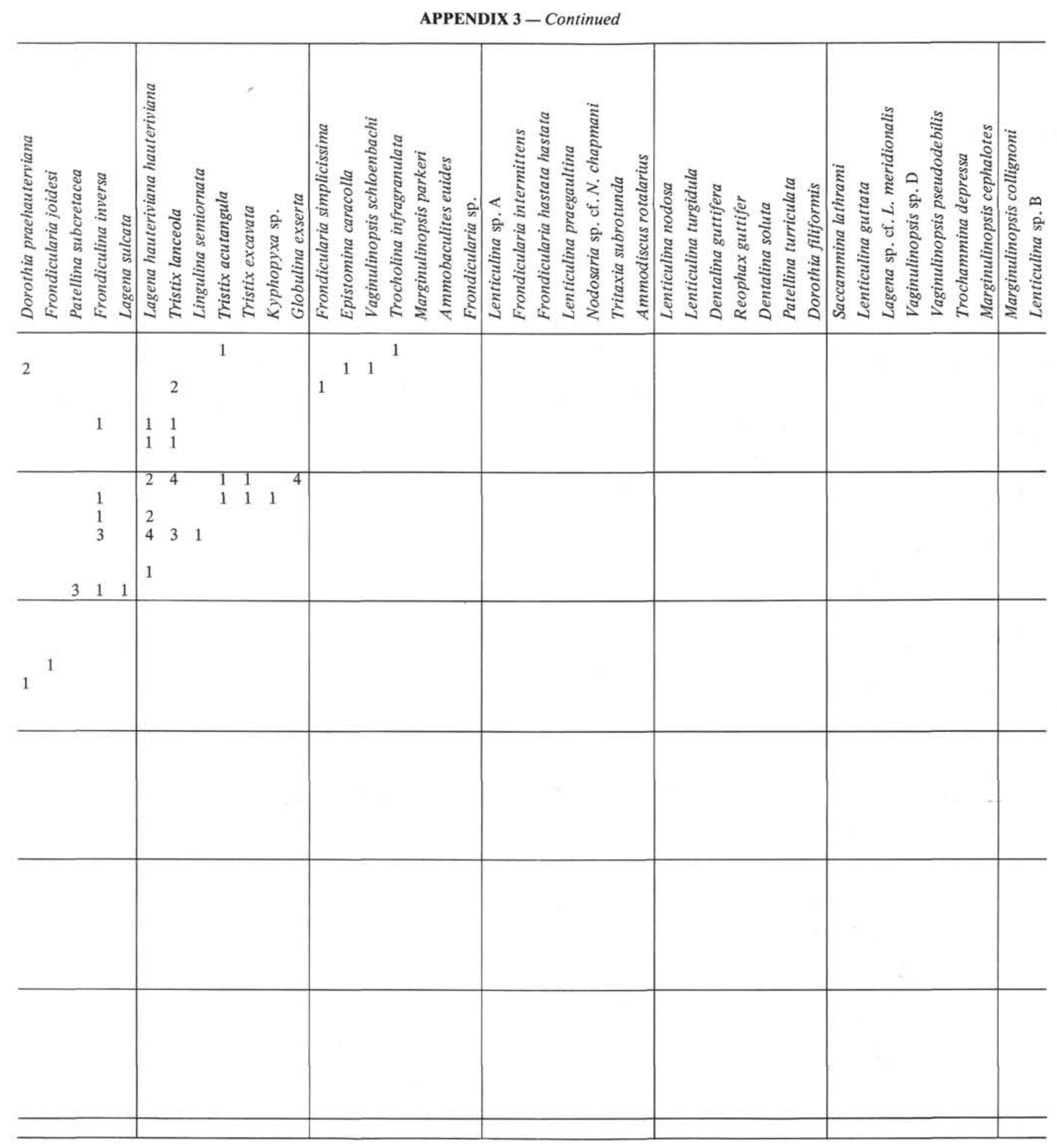

425 
APPENDIX 3 - Continued

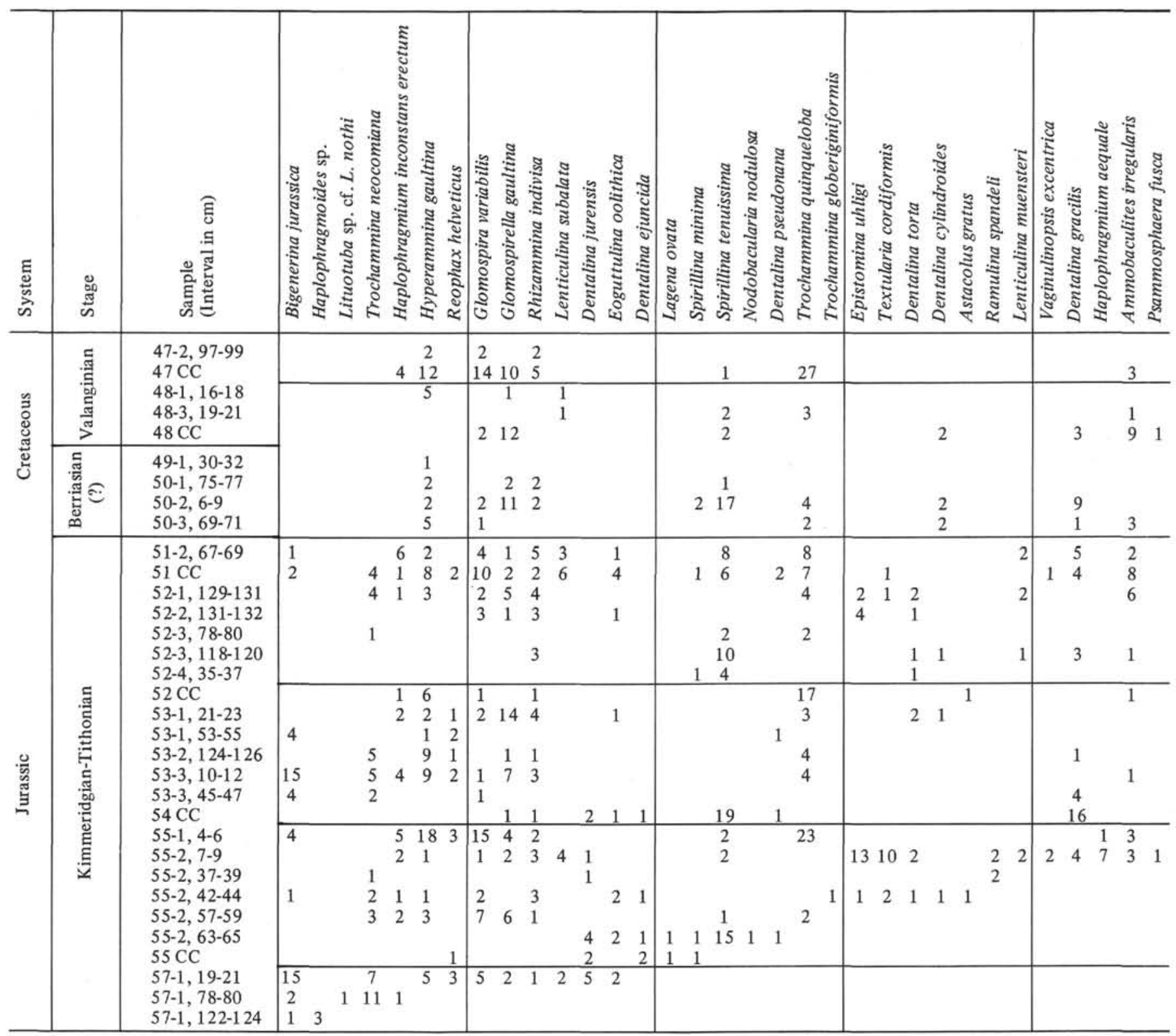




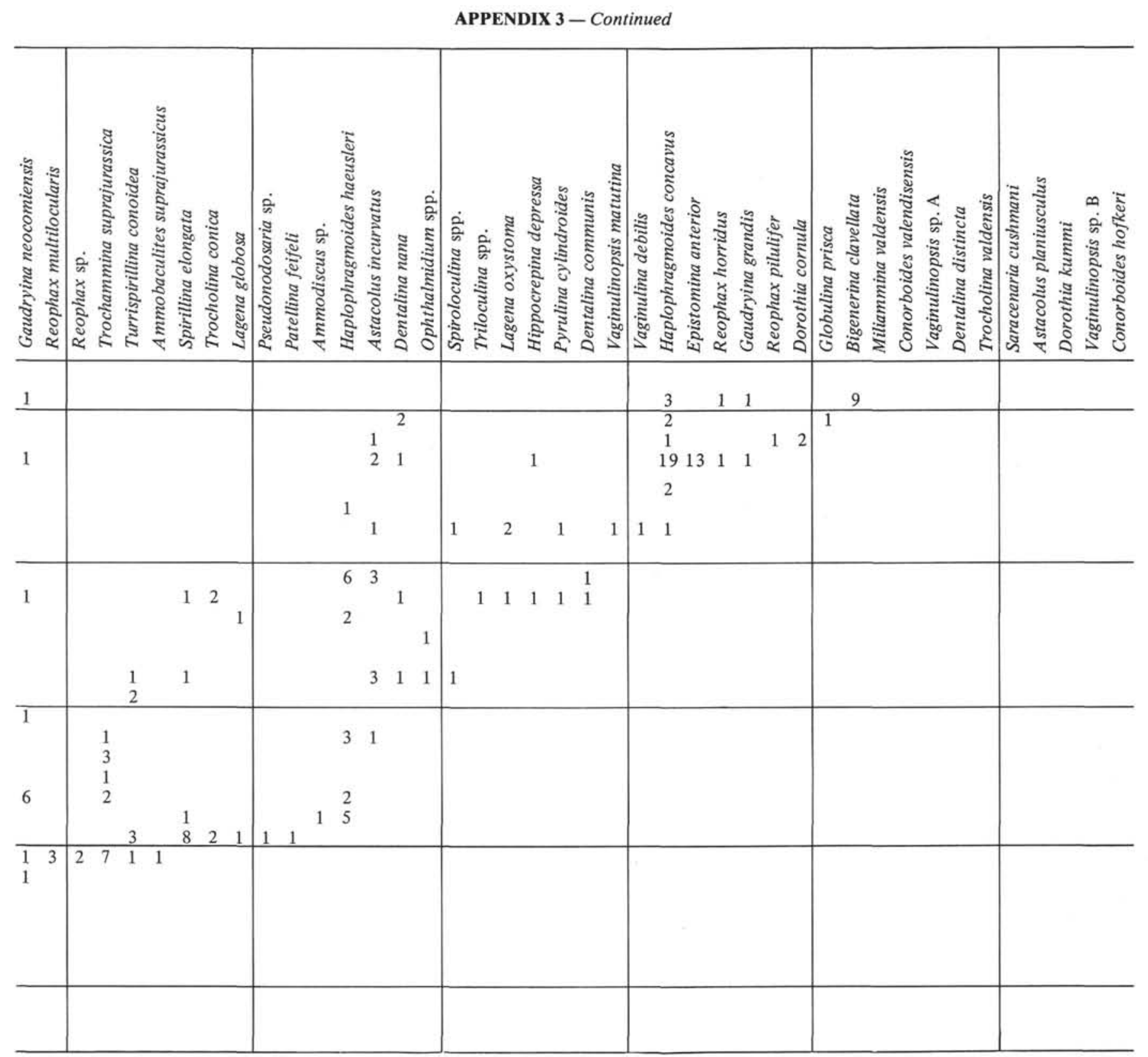

